Portland State University

PDXScholar

\title{
A geophysical study of the North Scappoose Creek, Alder Creek, Clatskanie River lineament, along the trend of the Portland Hills fault, Columbia County, Oregon
}

Nina Haas

Portland State University

Follow this and additional works at: https://pdxscholar.library.pdx.edu/open_access_etds

Part of the Geology Commons, and the Tectonics and Structure Commons Let us know how access to this document benefits you.

\section{Recommended Citation}

Haas, Nina, "A geophysical study of the North Scappoose Creek, Alder Creek, Clatskanie River lineament, along the trend of the Portland Hills fault, Columbia County, Oregon" (1982). Dissertations and Theses. Paper 3254.

https://doi.org/10.15760/etd.3244

This Thesis is brought to you for free and open access. It has been accepted for inclusion in Dissertations and Theses by an authorized administrator of PDXScholar. Please contact us if we can make this document more accessible: pdxscholar@pdx.edu. 
AN ABSTRACT OF THE THESIS OF Nina Haas for the Master of Science in Geology presented December 15, 1982.

Title: A Geophysical Study of the North Scappoose Creek Alder Creek - Clatskanie River Lineament, Along the Trend of the Portland Hills Fault, Columbia County, Oregon.

APPROVED BY MEMBERS OF THE THESIS COMMITTEE:

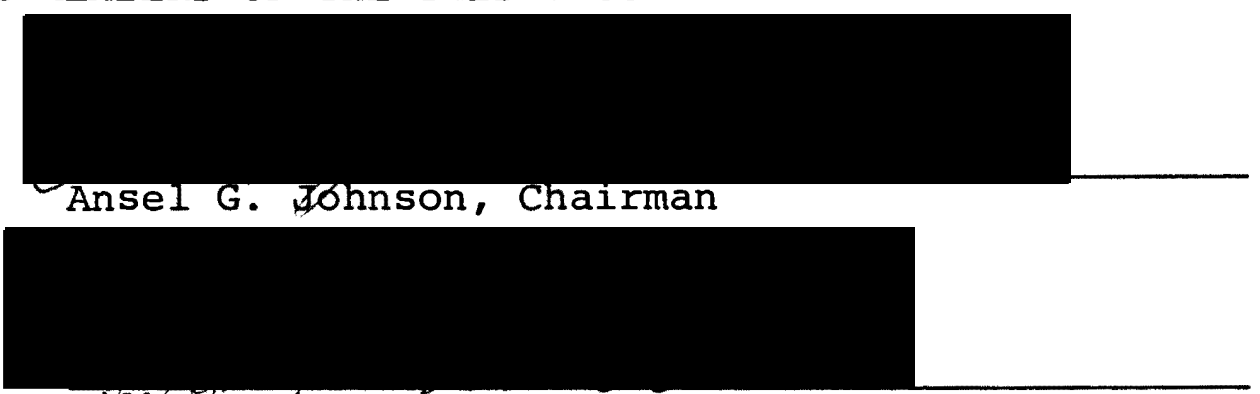

Gilbert T. Benson

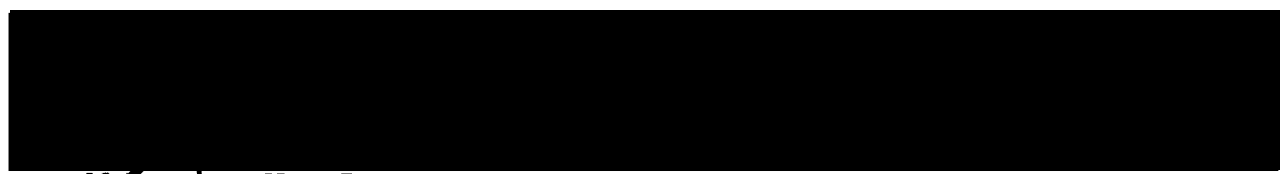

Wárvin $\mathrm{H}$. Beeson

The Portland Hills fault forms a strong northwest trending lineament along the east side of the Tualatin Mountains. An en echelon lineament follows North Scappoose Creek, Alder Creek, and the Clatskanie River along the same trend, through Columbia County, oregon. The possibility that this lineament follows a fault or fault zone was investigated in this study. Geophysical methods were used, with seismic 
refraction, magnetic and gravity lines run perpendicular to the lineament. The seismic refraction models indicate the near surface basalt is broken in many places, with $15-30$ meters (50 - 100 feet) vertical displacement, down to the west, at Bunker Hill along the Alder Creek fault. Gravity models required a faulted zone approximately two kilometers wide across the lineament. The proposed fault zone is more clearly defined in the south, becoming more diffuse and branching in the northern part of the study area. The Bouguer gravity values from this study distort the -40 milligal contour farther to the northwest than is shown on the Complete Bouguer Gravity Anomaly Map of Oregon (Berg and Thiruvathukal, 1967b). The existence of sharp topographic features and the geophysical evidence indicate fault activity along the zone. 
A GEOPHYSICAL STUDY OF THE NORTH SCAPPOOSE CREEK ALDER CREEK - CLATSKANIE RIVER LINEAMENT, ALONG THE TREND OF THE PORTLAND HILLS FAULT, COLUMBIA COUNTY, OREGON

by

NINA HAAS

A thesis submitted in partial fulfillment of the requirements for the degree of

\author{
MASTER OF SCIENCE \\ in \\ GEOLOGY
}

Portland State University 
TO THE OFFICE OF GRADUATE STUDIES AND RESEARCH:

The members of the committee approve the thesis of Nina Haas presented December 15, 1982.

Ansel G. Johnson, Chairman

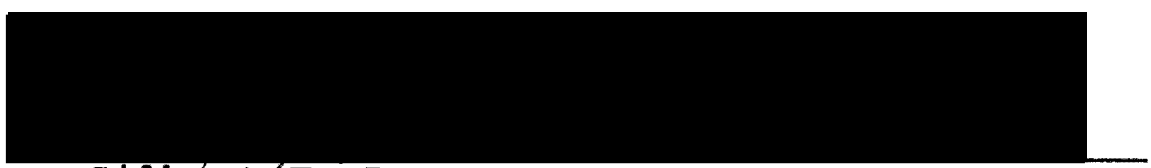

Gilbert'T. Benson

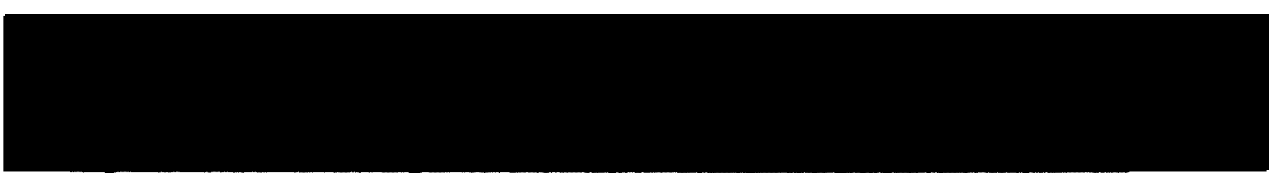

Zarvin H. Beeson

APPROVED :

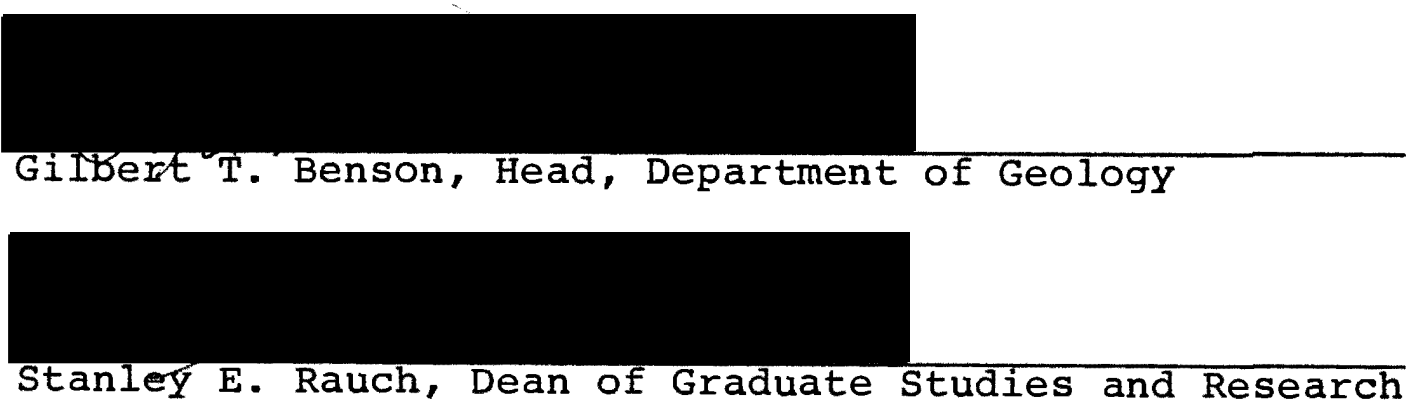




\section{ACKNOWLEDGEMENTS}

I would like to thank Dr. R. W. Couch at Oregon State University for loaning the gravimeter and thumper, and for his advice; Steve Pitts and Northwest Geophysical Associates, Corvallis, for computer assistance with corrections to the gravity data; and Longview Fibre Company for allowing access to their timberlands.

Funding for this study was from Reichhold Energy Corporation, Tacoma, Washington, and St. Helens, Oregon, and the Paul Howell Fund, administered by the Geology Department of Portland State University.

Special thanks are due Dr. Ansel Johnson, my thesis advisor, Dr. Tom Benson and Dr. Marvin Beeson, my thesis committee, all who gave advice and assistance, and especially to my friends who helped with the field work. 
TABLE OF CONTENTS

PAGE

ACKNOWLEDGEMENTS • • • • • • • • • • • • • • •

iii

LIST OF TABLES . . . . . . . . . . . . . . . v vi

LIST OF FIGURES . . . . . . . . . . . . . . . vii v vi

INTRODUCTION . . . . . . . . . . . . . . . . . 1

PURPOSE .................... . . . 1

LOCATION . . . . . . . . . . . . . 1

PREVIOUS WORK . . . . . . . . . . . 5

GEOLOGIC SETTING • • • • . • • • • • • . • . 7

NORTHWESTERN OREGON, COLUMBIA COUNTY • • • • • 7

Stratigraphy

Structure

TECTONIC HISTORY . . . . . . . . . . . .

METHODS OF INVESTIGATION . . . . . . . . . .

LINEAMENT ANALYSIS . . . . . . . . . . 15

WELL LOGS • • • • . . . . . . . . . . 17

GRAVITY . . . . . . . . . . . . . 22

Purpose

Field Procedure

Regional Trend

Data Reduction

Equipment Used

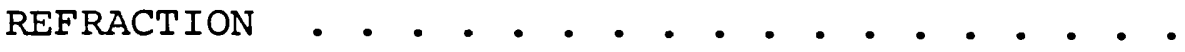


PAGE

Data Reduction

Equipment Used

MAGNETICS • • • • • • • • • • • . • • • • • •

Purpose

Field Procedure

Data Reduction

Equipment Used

MODELLING AND RESULTS - • • • • • • • . • • • • •

GRAVITY • • • • • • • • . • • • • • . •

General

Regional Models

Local Models

Comparison

REFRACTION

General

Bunker Hill Line

Shaffer Road Line

Little Clatskanie River Road Line

Comparison

MAGNETICS • • • • • • • • • • • • . • •

General

Bunker Hill Line

Shaffer Road Iine

Little clatskanie River Road Line

Comparison

DISCUSSION AND CONCLUSIONS • • • • • • • • • • • •

REFERENCES • • • • • • • • • • • • • • • • • • • • •

APPENDIX A. GRAVITY DATA AND FORMULAS • • • • • • •

APPENDIX B. REFRACTION DATA AND FORMULAS • • • • • 101

APPENDIX C. MAGIETIC DATA • • • • • • • • . • • 106

APPENDIX D. WATER WELL LOGS . . • . . . . . . . . 109 


\section{LIST OF TABLES}

TABLE

PAGE

I Complete Bouguer Gravity Anomaly Values for Apiary, Pittsburg-Yankton and Spitzenberg Gravity Lines . . . . . . . . . . . 


\section{LIST OF FIGURES}

FIGURE

PAGE

1. Regional Map . . . . . . . . . . . . . . 2

2. Study Area . . . . . . . . . . . . . . . 4

3. Formations in Study Area . . . . . . . . . 8

4. Lineaments in Columbia County, Oregon . . . . 16

5. North Scappoose Creek - Alder Creek -

Clatskanie River Lineament (SLAR) . . . . 18

6. Lineament, North Scappoose Creek -

Alder Creek (photo) . . . . . . . .

7. Lineament, Clatskanie River (photo) . . . . 20

8. Lineament, North of Apiary-Oak Ranch Road . . 21

9. Regional Bouguer Gravity Map . . . . . . . 26

10. Bunker Hill Refraction Line . . . . . . . 30

11. Typical Refraction Line Layout . . . . . . 31

12. Shaffer Road and Little Clatskanie River

Road Refraction Lines . . . . . . . 32

13. Location of Regional Gravity Models . . . . . 39

14. Apiary Regional Gravity Model . . . . . . . . 41

15. Spitzenberg Regional Gravity Model . . . . . 42

16. Apiary Local Gravity Model . . . . . . . . 45

17. Spitzenberg Local Gravity Model . . . . . . . 46

18. Bouguer Gravity Anomaly Contour Map . . . . . 48 
19. Bunker Hill Refraction, Time-distance Plot . .

20. Bunker Hill Refraction, Projected

Cross Section . . . . . . . . . . .

21. Shaffer Road Refraction, Time-distance

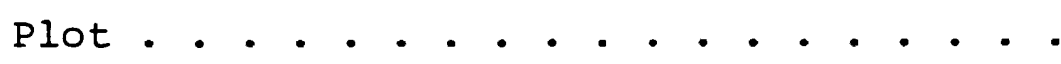

22. Shaffer Road Refraction, Projected

Cross Section . . . . . . . . .

23. Lineament offset at North End of

Shaffer Road . . . . . . . . .

24. Little Clatskanie Refraction, Time-

distance plot . . . . . . . . .

25. Little clatskanie Refraction, Projected

Cross Section . . . . . . . . . . .

26. Bunker Hill Magnetic Data, Graph . . . . .

27. Bunker Hill Magnetic Data, Projected

Cross Section . . . . . . . . . . . .

28. Shaffer Road Magnetic Data, Graph . . . .

29. Shaffer Road Magnetic Data, Projected

Cross Section . . . . . . . . . .

30. Little Clatskanie Magnetic Data, Graph . . .

31. Little Clatskanie Magnetic Data, Projected Cross Section . . . . . . . . . .

32. Complete Bouguer Gravity Map of Northwestern Oregon with Study Data. . . . . . . 


\section{INTRODUCTION}

\section{PURPOSE}

The Portland Hills fault lineament extends southeast into the upper Clackamas River drainage. This study was undertaken to investigate 1) the possible extension of the Portland Hills fault lineament to the northwest, into Columbia county, Oregon, and 2) the form this extension would take, whether as a continuation of the Portland Hills fault itself, as another fault along the same trend, or as a zone of parallel or en echelon faults. The thick vegetative cover in northwestern oregon makes geophysical and remote sensing techniques the most logical way to investigate this problem. Photo and map analysis, and a combination of gravity, magnetic, and seismic refraction surveys were used to study the lineament trends.

\section{LOCATION}

This study was conducted in Columbia County, Oregon. Three gravity lines, and three refraction and magnetics lines were run (Figure 1).

The Spitzenberg gravity line begins at the intersection of Kappler Road and the st. Helens-Pittsburg (Old Vernonia) Road in $T 4 N$, RIW, Sec. 6, and follows Kappler Road to Cater Road $(\mathrm{T} 4 \mathrm{~N}, \mathrm{R} 2 \mathrm{~W})$, through Spitzenberg, then follows 


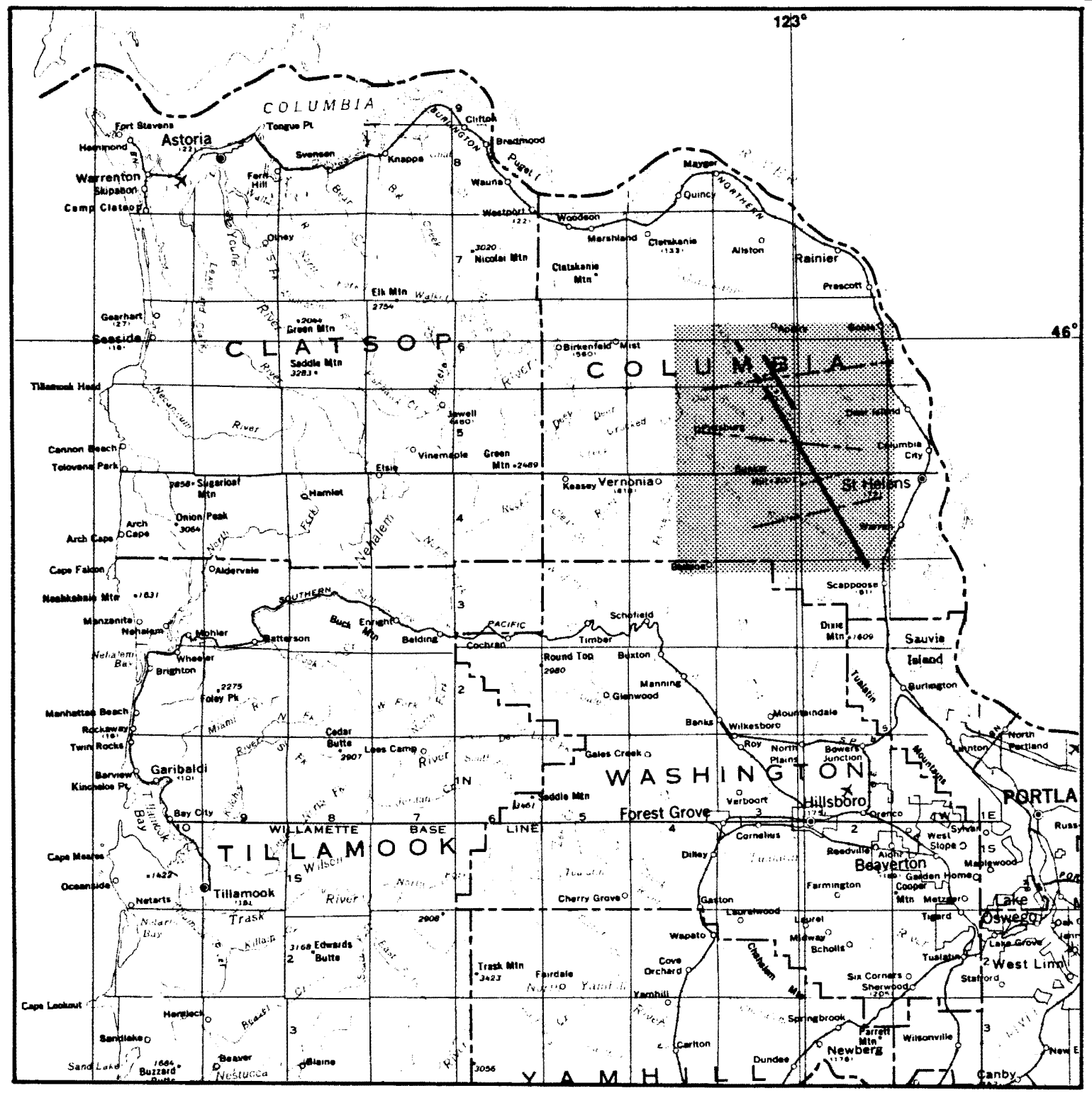

Study area

Lineament

Pefraction/magnetic line

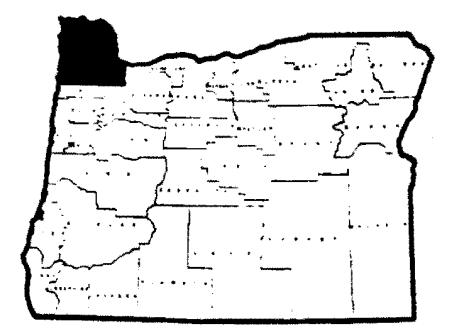

Gravity lino

Figure 1. Regional map (from USGS map of Oregon, 1979 rev. , 1:500,000). 
the Scappoose-Vernonia Highway west past Chapman and Tunnel Road to the line's western end in $T 4 N, R 3 W$, Sec. 16 (Figure 2).

The Pittsburg-Yankton gravity line follows the st. Helens-Pittsburg (Old Vernonia) Road west from Yankton school (T5N, R2W, SW corner of Sec. 36) to its intersection with the Scappoose-Vernonia Highway and Oregon Highway 47 (T5N, R4W, Sec. 23) near Pittsburg (Figure 2).

The Apiary gravity line begins at the intersection of Tide Creek Road and U.S. Highway 30 (T6N, R2W, Sec. 36) and proceeds west via Tide Creek Road, Anliker Road, Meissner Road, Janshaw Road, Little Clatskanie River Road and the Apiary-Oak Ranch Road to the intersection with Oregon Highway 47 (T5N, R4W, Sec. 3) about 13 kilometers ( 8 miles) north of Vernonia (Figure 2).

The Bunker Hill refraction and magnetics line follows Bunker Hill Road east and west of its intersection with the Wilark 247 Road, in T4N, R2W, Sec. 6 (Figure 2). The Shaffer Road refraction and magnetics line follows the northernmost 1.5 kilometers $(0.9$ miles) of Shaffer Road to its intersection with the Apiary-Oak Ranch Road, then east along the Apiary-Oak Ranch Road for 0.3 kilometer $(0.2 \mathrm{mile})$ in $\mathrm{T} 5 \mathrm{~N}, \mathrm{R} 3 \mathrm{~W}$, Sec. 3. The Little Clatskanie refraction and magnetics line follows the Little Clatskanie River Road east from the Apiary-Oak Ranch Road to the Little Clatskanie River, T6N, R3W, Sec. 34 and 35 (Figure 2). 


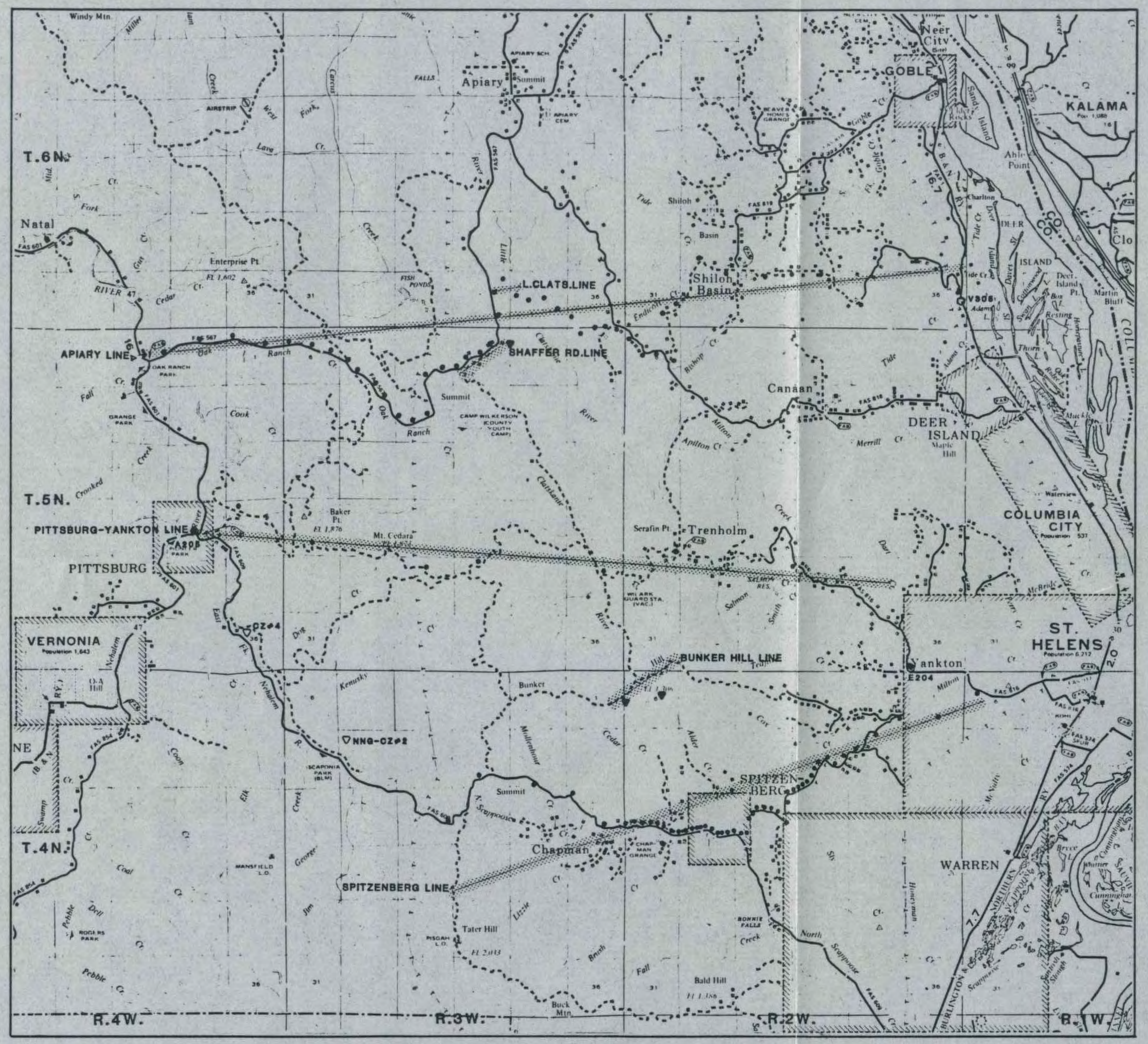

Geophysical line

- Gravity station

Deep well

Water well

- Building

Benchmark to anchor surveying

Figure 2. Study area (from map of Columbia County, Oregon, prepared by Oregon State Hwy. Division, 1971, scale 1:62,500). 
The Shaffer Road and Little clatskanie refraction and magnetics lines are located along sections of the Apiary gravity line. The Pittsburg-Yankton gravity line is 8.4 kilometers $(5.2$ miles) southeast of the Apiary line, and the Bunker Hill refraction and magnetics line is 3.5 kilometers (2.2 miles) south of the Pittsburg-Yankton gravity line. The Spitzenberg gravity line is 4.5 kilometers ( 2.8 miles) south of the Bunker Hill line.

\section{PREVIOUS WORK}

The Portland Hills fault, along the eastern edge of the Tualatin Mountains (Portland Hills), has been studied by Johnson and others (1977) and Beeson and others (1976), who noted gravity anomalies and offset Columbia River basalt flows. Schlicker and others (1964) and Couch and Lowell (1971) noted earthquake epicenters and their probable agreement with postulated faults in the Portland area. The gravity work of Jones (1977) and Perttu (1980) could be interpreted as evidence of the fault. Topographic evidence for the Portland Hills fault is cited by Beeson and others (1976) and Balsillie and Benson (1971). Extension of the Portland Hills fault trend into the Clackamas River drainage has been studied by Schmela (1971) and Anderson (1978).

The structure and stratigraphy of northwestern oregon and Columbia County has been described by Diller (1896), Newton and Van Atta (1976), Benson and Donovan (1974), Warren, Norbisrath and Gravetti (1945), Snavely and Wagner 
(1964), Trimble (1963), Kelty (1981) and Kadri (1982) among others. The St. Helens Quadrangle has been described by Wilkinson and others (1946).

Gravity of northwestern Oregon has been surveyed and analyzed by Bromery and Snavely (1964), Berg and Thiruvathukal (1967), and Thiruvathukal and others (1970). Gravity surveys in the Portland area have been conducted by Schmela (1971), Cash (1973), Johnson and others (1977), Jones (1977) and Perttu (1980).

Regional tectonic models have been offered by Atwater (1970) and Dickinson (1976, 1979). The Basin and Range province in Oregon was discussed by Lawrence (1976) and possible rotation of northwestern Oregon was discussed by Beck and Burr (1979), Magill and Cox (1981), and Simpson and Cox (1977). These models are described in the section on tectonic history. 
GEOLOGIC SETTING

NORTHWESTERN OREGON - COLUMBIA COUNTY

Stratigraphy

A chart of formations in the study area is given in Figure 3. The following description is based primarily on the work of Newton and Van Atta (1976), Wilkinson and others (1946) and Snavely and wagner (1964).

The upper Eocene Goble Volcanic series is the oldest unit in the study area and is considered slightly younger than the Tillamook-Siletz River Volcanics. The Goble Volcanics consist of dark grey submarine and subaerial basalt flows, breccias, and pyroclastics, often with calcite or zeolite filling fractures, intercalated with cowlitz Formation sediments (Newton and Van Atta, 1976). The Cowlitz sedimentary rocks consist of siltstone, sandstone, shale, and in the lower part of the section, conglomerates. These sediments were deposited in near shore marine (littoral to sublittoral) environments. The siltstone is arkosic, finely laminated, argillaceous, and micaceous, with low angle cross lamination and cut and fill structures. The sandstone is grey, arkosic, silty, micaceous, and fine to medium grained. The shale is dark grey, thinly laminated, and micaceous, with some sandstone and tuffs (Newton and Van Atta, 1976; Snavely and Wagner, 1964). 


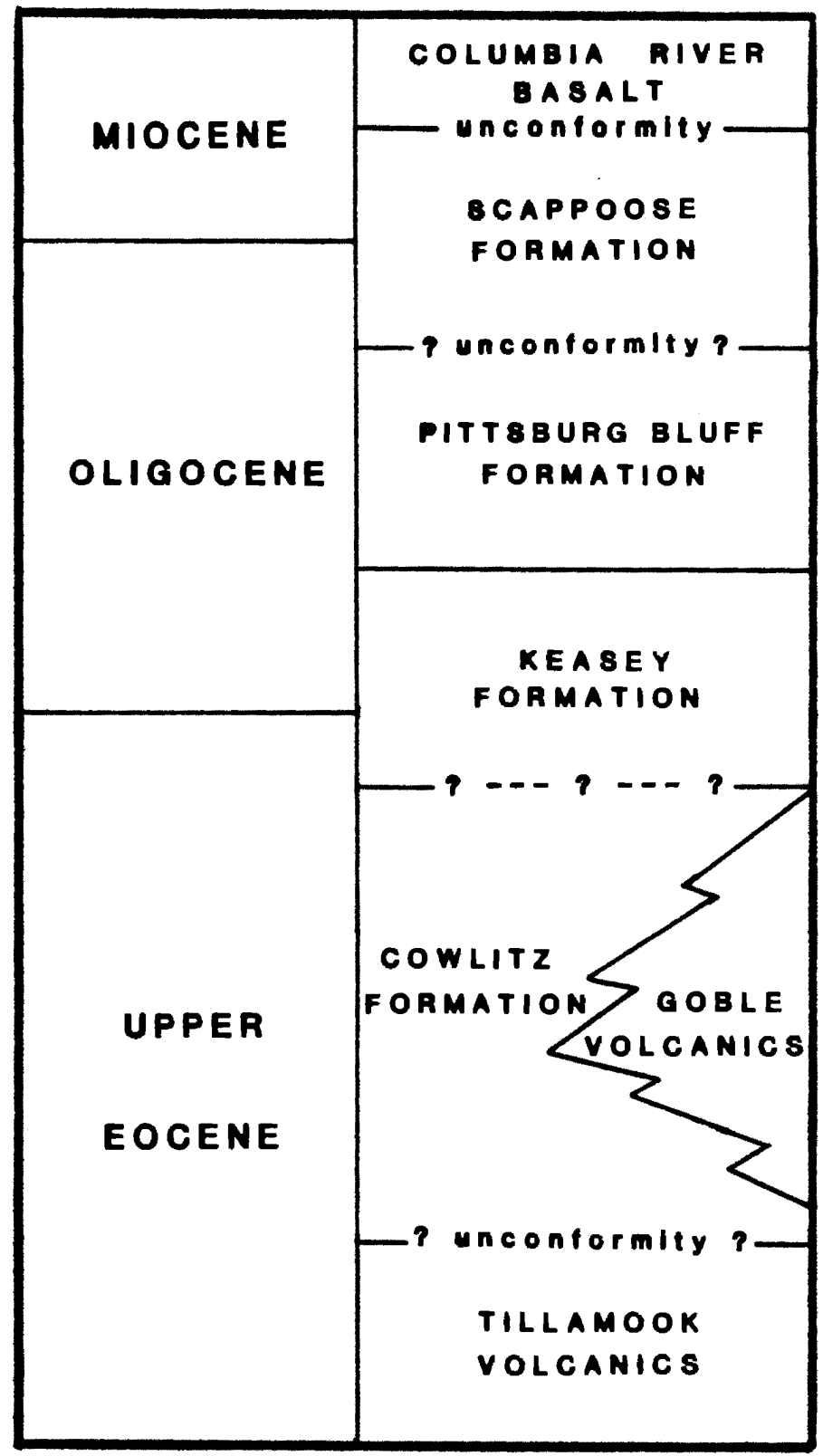

Figure 3. Formations in study area (from Kelty 1981, Newton and Van Atta 1976). 
The upper Eocene to lower Oligocene Keasey Formation rests conformably on the cowlitz Formation (Newton and Van Atta, 1976). The Keasey sediments were deposited in a bathyal to sub-bathyal environment and consist of tuffaceous mudstone, siltstone and shale, with some glauconitic sand. The Keasey beds are typically greenish grey and weather to a buff color. Fossils are abundant and structures include cross laminations, ripple laminations and load casts. Limestone concretions are found locally. An unconformity separates the Keasey from the younger Pittsburg Bluff Formation (Wilkinson and others, 1946; Newton and Van Atta, 1976).

The middle Oligocene to lower Miocene Pittsburg Bluff and Scappoose Formations are similar, and have been mapped as undifferentiated (Newton and Van Atta, 1976). The lower Pittsburg Bluff sediments are similar to the Keasey but contain more siltstone (Newton and Van Atta, 1976). Concretionary limestone beds are also found in the Pittsburg Bluff Formation. The upper Pittsburg Bluff beds are arkosic sandstone and siltstone. The sandstones are medium to fine grained, locally cross bedded, with iron stained laminae, and with wood fragments and locally developed coal. The Pittsburg Bluff sediments were deposited in shallow marine and delta environments, and are very fossiliferous. White ash layers, now altered to clay, are present. The scappoose Formation, also fossiliferous, is composed of tuffaceous, arkosic sandstone, siltstone and mudstone, more quartzose, 
but with less ash than the Pittsburg Bluff, and is a shallow marine, brackish water deposit. There is a disconformity between the Pittsburg Bluff and Scappoose Formations (Kelty, 1981; Warren and Norbisrath, 1946; Newton and Van Atta, 1976).

The Miocene Columbia River Basalt Group unconformably overlies the Scappoose Formation (Wilkinson and others, 1946). It is grey-black, aphanitic, and vesicular near flow tops (Snavely and Wagner, 1964). Most of the Columbia River basalt has been weathered at the surface to ferruginous bauxite, often containing pisolites. Below the surface the ferruginous bauxite contains angular, broken basalt fragments which appear to grade down gradually to solid rock. In the upper portions of the weathered layer the basalt fragments are commonly completely altered so only relict texture remains. Limonite staining is common (Wilkinson and others, 1946). The groundmass is altered to an orange clay and the feldspar phenocrysts are altered to white clay.

For geophysical modelling the Keasey, Pittsburg Bluff and Scappoose Formations have been grouped together as "sediments", and the Columbia River basalt and Goble Volcanics as "basalt". The Cowlitz Formation can fit into either category depending on its local expression since it contains both sediments and interbedded basalt. The density of the upper Eocene basalts is about $2.8 \mathrm{~g} / \mathrm{cm}^{3}$ (range 2.45 $2.97)$; that of the Columbia River basalt is $2.8 \mathrm{~g} / \mathrm{cm}^{3}$ 
(range $2.31-2.98)$; and the late Eocene to late Oligocene sediments are about $2.4 \mathrm{~g} / \mathrm{cm}^{3}$ (Snavely and Wagner, 1964 ; Bromery and Snavely, 1964; Pfaff, 1981). Magnetic susceptibility of upper Eocene rocks has been measured as .00046 to $.002 \mathrm{cgs}$ units and the Miocene volcanics as .00015 to .002 cgs units. These susceptibilities agree with averages from other sources for basalt, such as .007 (Dobrin, 1976), .006 (Telford and others, 1976) and .0005 to .0017 (Heiland, 1968). Seismic velocities ( $P$ wave) are estimated, for local near surface materials, to be about $1830 \mathrm{~m} / \mathrm{s}(6000 \mathrm{f} / \mathrm{s})$ for sediments and about $3050-4570 \mathrm{~m} / \mathrm{s}(10,000-15,000 \mathrm{f} / \mathrm{s})$ for volcanics (Mike Alger, personal communication, 1982). These values agree with other sources which list $400-610$ $\mathrm{m} / \mathrm{s}(1300-2000 \mathrm{f} / \mathrm{s})$ for clayey soil, 915 - $1800 \mathrm{~m} / \mathrm{s}(3000$ - $5900 \mathrm{f} / \mathrm{s})$ for clay and claystone, 1830 - $2440 \mathrm{~m} / \mathrm{s}(6000$ $8000 \mathrm{f} / \mathrm{s})$ for sandstone, and $2750-4270 \mathrm{~m} / \mathrm{s}(9000-14,000$ $\mathrm{f} / \mathrm{s}$ ) for fractured basalt (Redpath, 1973).

\section{Structure}

Heavy vegetation and poor exposure limit the quality of the structural interpretation from surface data. The Tillamook Volcanics and northern Coast Range form a northward plunging anticline (or high) with the Eocene sediments deposited around it (Newton and Van Atta, 1976). The Oligocene sediments have been deposited on the eastern side only. The Goble Volcanics also formed a topographic high. Uplift and erosion in the early Miocene produced an 
erosional surface with a relief of approximately 100 meters (300 feet) and some gentle folding (Wilkinson and others, 1946; Newton and Van Atta, 1976), which was overlain by the Columbia River basalt flows. Northwest - southeast folds which cross the area are believed to have formed during the time the Columbia River basalt was being laid down (Newton and Van Atta, 1976). Mapped faults are oriented northwest - southeast, east - west, and northeast - southwest (Newton and Van Atta, 1976; Kelty, 1981). Evidence of vertical movement can be found in the field but unequivocal evidence of strike-slip movement has not been found. The principal compressional stress is north - south (Crosson, 1972; Dehlinger and Couch, 1969), and this would favor strike-slip movement on the northeast and/or northwest trending faults.

\section{TECTONIC HISTORY}

There are several models of the Mesozoic and Cenozoic history of northwestern Oregon, however much work remains to be done before any one is generally agreed upon. Most researchers agree that the Siletz River - Tillamook Volcanics are oceanic islands which were rafted in by eastward or northeastward moving plates, and collided with the Mesozoic rocks of the North American continent during the Cenozoic era (Dickinson, 1976). A subduction zone was located west of the continental mass, but its location and that of the coastline during the Mesozoic and early Cenozoic are not known. Most hypotheses, however, place the 
subduction zone and continental coastline well east of the present southern Washington - northern Oregon coastline (Dickinson, 1976, 1979; Simpson and Cox, 1977; Magill and Cox, 1980; Hamilton, 1978). During the early Eocene the subduction zone moved from east of the present Cascades to the present inner continental shelf of oregon (Snavely and others, 1980). Paleomagnetic evidence has been interpreted to indicate Eocene and later rotation of the Coast Range Klamath Mountain block. The oldest rocks of the Coast Range show about $75^{\circ} \pm 17^{\circ}$ clockwise rotation and younger rocks show progressively less rotation. The Goble Volcanic series rotated about $25^{\circ} \pm 13^{\circ}$, but possibly as a separate block (Beck and Burr, 1979). The Coast Range rotation is suggested as a two phase rotation, about $50^{\circ} \pm 15^{\circ}$ during the Eocene $\left(40-50\right.$ mybp) and about $25^{\circ} \pm 20^{\circ}$ during the Miocene Basin and Range extension (20 mybp). The earlier rotation may have been associated with accretion and/or shear associated with plate movement (Beck and Plumley, 1980; Magill and others, 1981, 1982; Magill and Cox, 1980, 1981; Simpson and Cox, 1977; Hamilton, 1978). The Coast Range does not appear to be an exotic terrane which was rafted in from a great distance as has been proposed for other West Coast terranes (Hamilton, 1978; Jones and others, 1982), but could have been formed nearby. The inclination of the remnant magnetism indicates no detectable northward movement of the block (Beck and Burr, 1979). The current tectonic status appears to be north - south compression with 
right lateral movement on northwest trending strike-slip faults due to possible subduction of the Farallon plate. The present location of the subduction zone is not known (Crosson, 1972; Dehlinger and Couch, 1969; Dehlinger, 1969). 


\section{METHODS OF INVESTIGATION}

\section{LINEAMENT ANALYSIS}

Side looking airborne radar (SLAR) $(1: 250,000)$, Landsat bands 6 and $7(1: 1,000,000)$, and high altitude U-2 (1:130,000) photographs were studied for lineaments. A map of the study area with significant lineaments noted is shown in Figure 4. The SLAR provided the best contrast and lineament enhancement. This is due primarily to the low spatial resolution, about 10 meters ( 30 feet), which acts as a filter to remove vegetation "noise" and enhances the topography (Sabins, 1978, p. 207). The radar look direction is south. Since features perpendicular to the look direction are enhanced and those parallel are subdued, north - south trending lineaments are not obvious. Some east - west artifacts are evident due to image quality and the mosaic process, especially in enlargements, and make special care necessary for recognition of true east - west lineaments.

The Landsat photos lacked contrast and sharpness. Band 6, visible light, and band 7, infrared, were examined. Band 7 was better for lineament analysis and was generally a better image than band 6 . Both SLAR and Landsat images were in black and white.

High altitude $(U-2)$ aerial photographs were also 


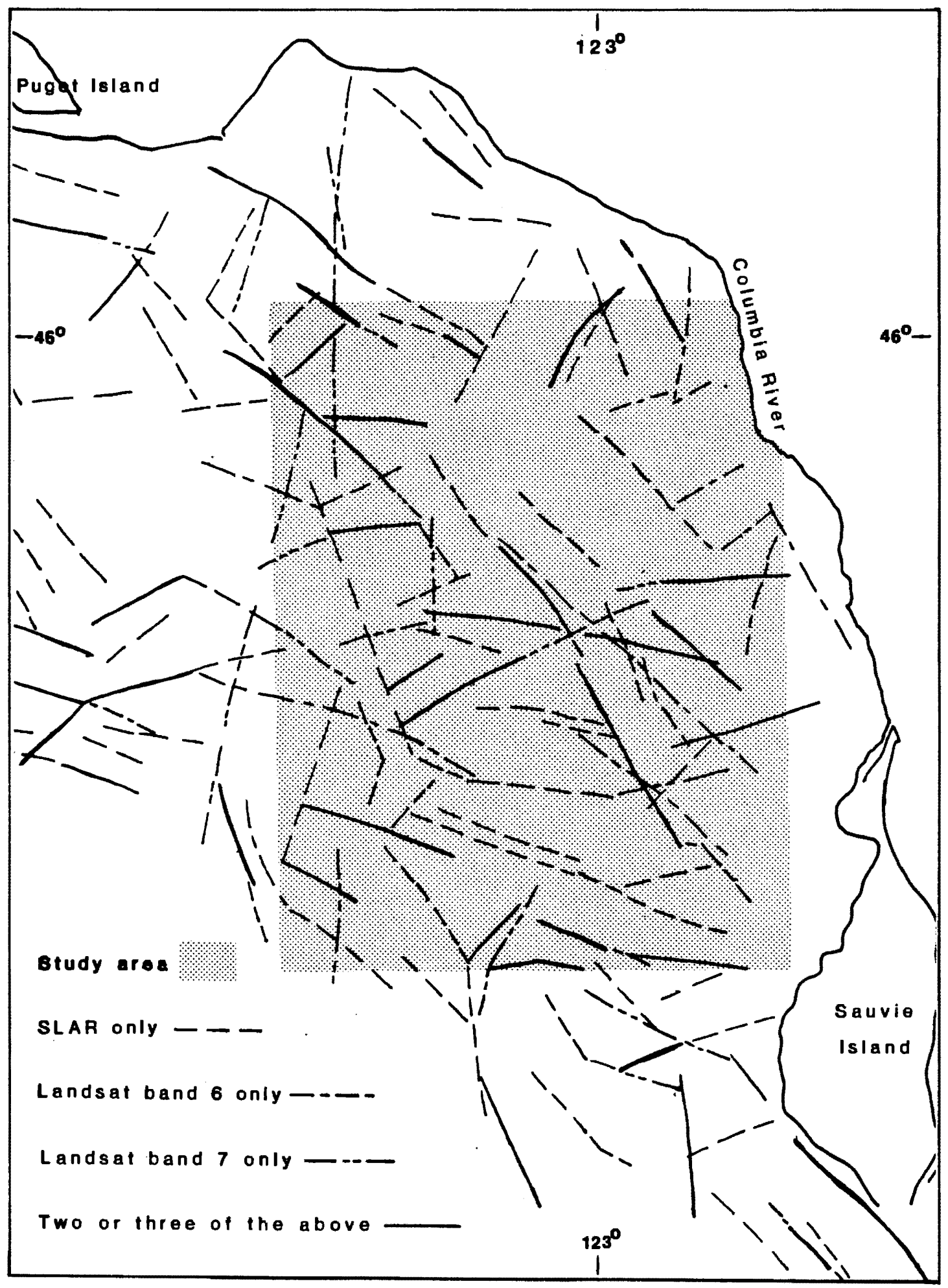

Figure 4. Lineaments in Columbia County, Oregon. 
examined for evidence of lineaments along the trend of the Portland Hills fault. The black and white photos were slightly dark but do show the lineaments. Color infrared photos were excellent and show topographic features quite well.

The smaller scale did not allow analysis of lineaments over as large an area as desired and these photographs were used primarily for detail and verification of linear features seen on the SLAR and Landsat photos.

The linear feature selected for study, North Scappoose Creek - Alder Creek - Clatskanie River, is prominent on SLAR, Landsat band 7 and U-2 photos (Figure 5). A small plane flight was also made over the area and the lineament showed up very prominently from 1067 meters (3500 feet), as seen in Figures 6,7 and 8 .

\section{WELL LOGS}

Lithologic and electric logs from deep oil and gas wells, and driller's logs for water wells in the area were examined. The deep wells are all located west of the study area and show thick sedimentary sequences, intercalated in some cases with the Goble Volcanic Series. Water wells are scattered throughout the area with depths varying from 15 meters (50 feet) to 183 meters (600 feet). Many water wells penetrated basalt and almost all were drilled through 3 to 46 meters (10 to 150 feet) of clay before hitting "broken rock" (weathered basalt?), sandstone or "shale" (mudstone?). 


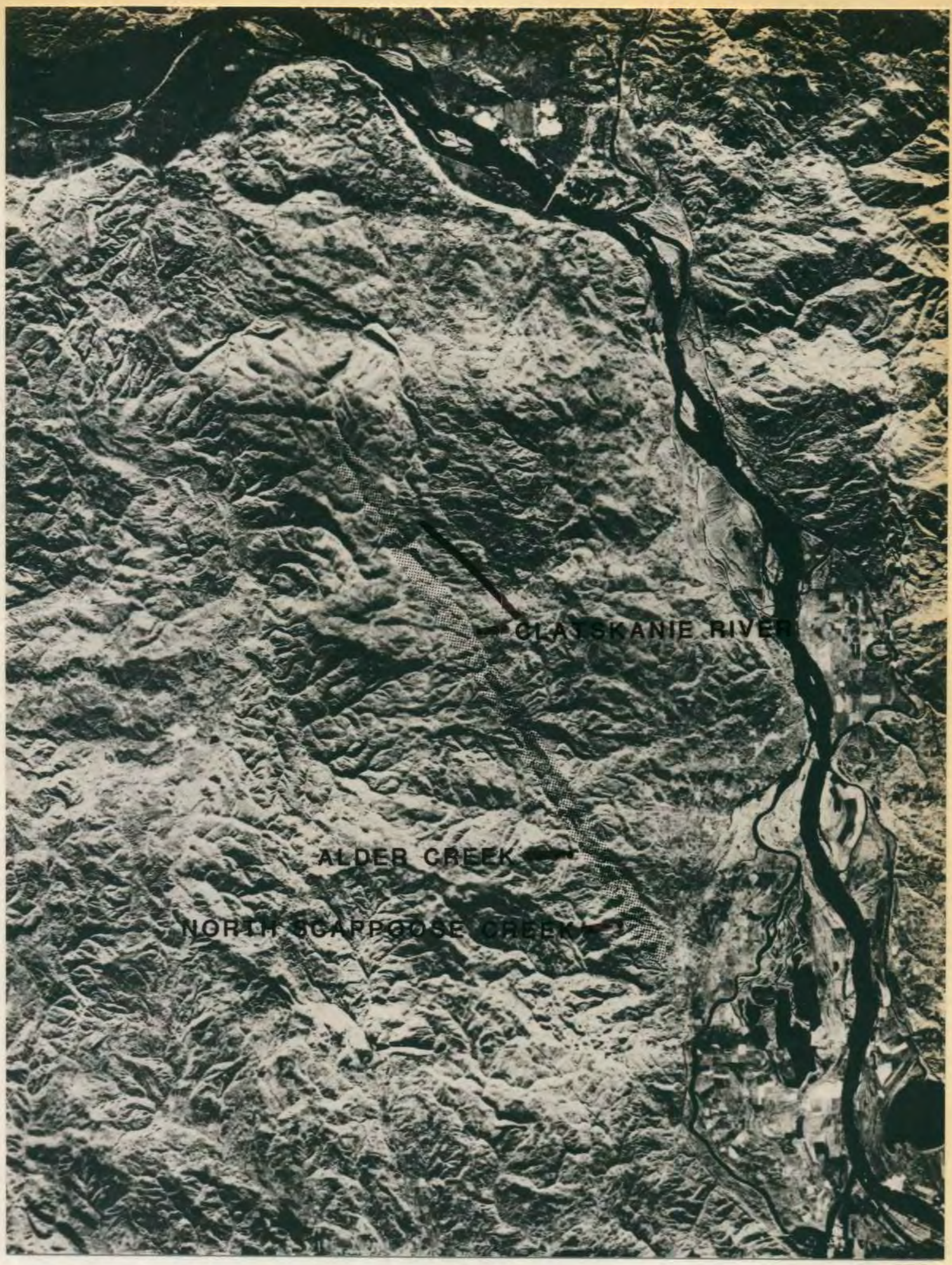

Figure 5. North Scappoose Creek - Alder Creek Clatskanie River lineament (SLAR). 


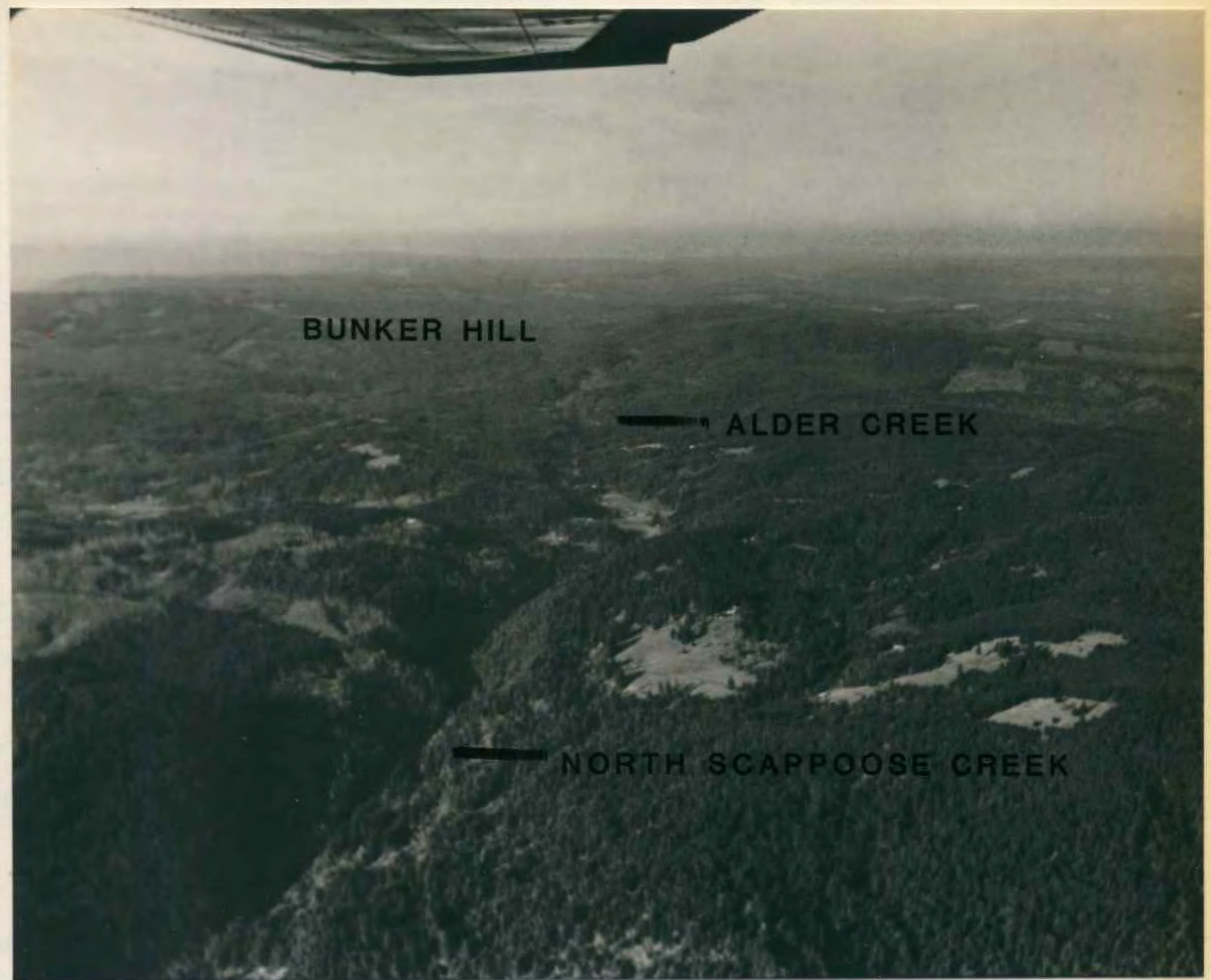

Figure 6. Lineament, North Scappoose Creek Alder Creek (photo). 
Figure 7. Lineament, Clatskanie River (photo). 


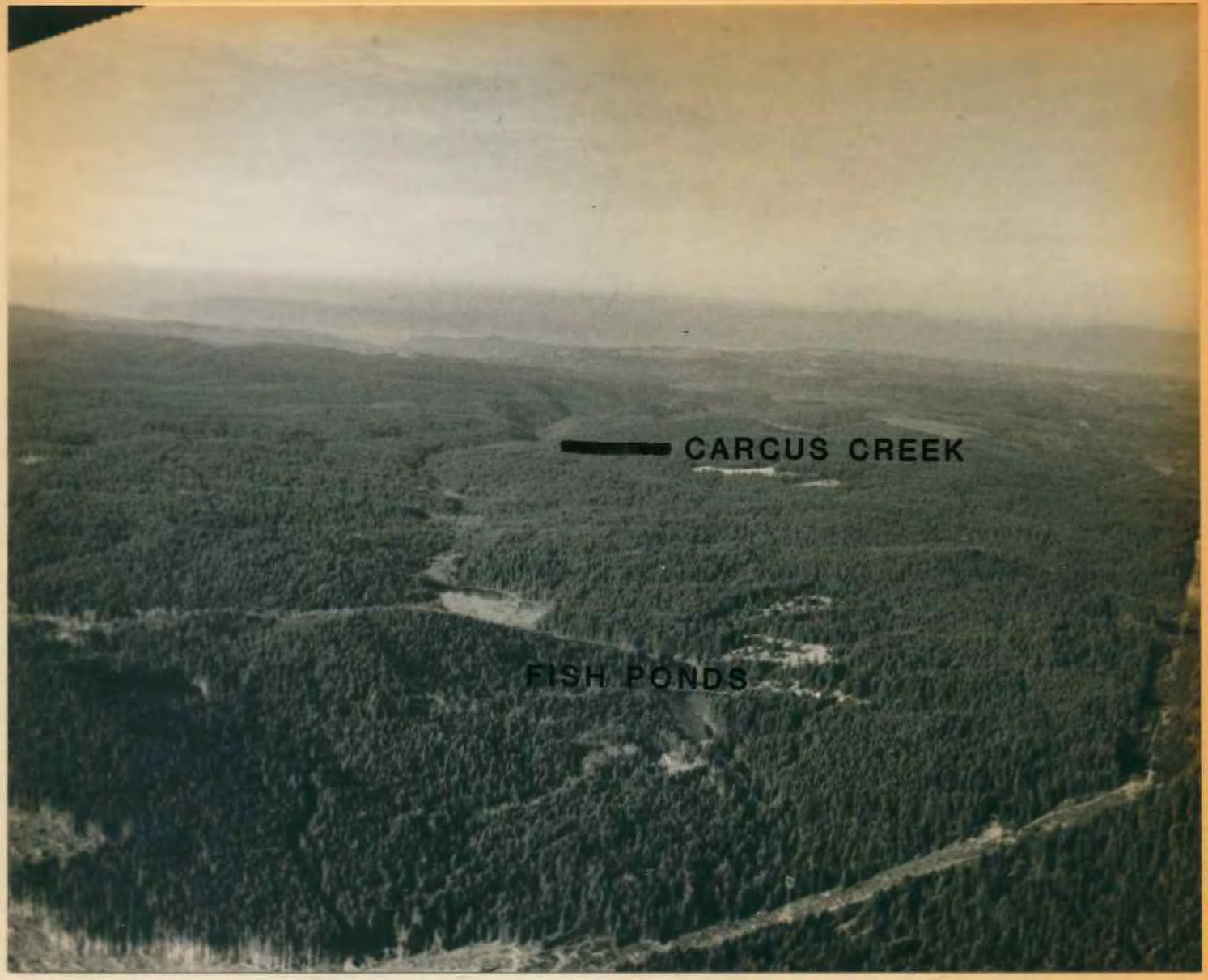

Figure 8. Lineament north of Apiary - Oak Ranch Road (photo). 
The basalt ranges from very thin ( 2 or 3 meters) in the southeastern part of the area to sixty or more meters in the northeast. Very few of the water wells were drilled through the basalt so there is only scattered data on the depth of the bottom of the Columbia River Basalt. The lack of good lithologic descriptions and imprecise locations are major drawbacks to depending on this data. Well data used in modelling is listed in Appendices $A$ and $D$.

\section{GRAVITY}

\section{Purpose}

A gravity survey was conducted to gather information for structural modelling of the area. The northwest trending lineaments along North Scappoose Creek, Alder Creek, the Clatskanie River (Shaffer Road), and the Little Clatskanie River were chosen for geophysical study (Figure 5). These lineaments follow the trend of the Portland Hills fault and have roads crossing them perpendicular to their trend. Three lines were run to give coverage over an area 16 kilometers (10 miles) along the lineament trend and 16 to 24 kilometers (10 to 15 miles) perpendicular to it, or approximately 325 square kilometers (125 square miles). The lines extend several kilometers beyond the lineaments both east and west to avoid the influence of edge effects on the modelling. The density contrasts found through the gravity modelling process should show the faulting, if it exists, as basalt $\left(\sim 2.8 \mathrm{~g} / \mathrm{cm}^{3}\right)$ is juxtaposed against sediments 
$\left(\sim 2.4 \mathrm{~g} / \mathrm{cm}^{3}\right)$. A total straight line distance of $60 \mathrm{kilo-}$ meters ( 37.5 miles) of gravity line was run.

\section{Field Procedure}

The three gravity lines chosen are described in the Location section. A straight line was drawn on the map approximately perpendicular to the lineament trend from one end of the line to the other, and distances between gravity stations were scaled off on the straight line and projected onto the roads. The road distance between stations is therefore variable. Gravity stations on the spitzenberg line are spaced 0.16 kilometer $(0.1$ mile) apart for about 4 kilometers $(2.5$ miles $)$ on either side of the North Scappoose Creek - Alder Creek lineament. For 1.5 kilometers ( 1 mile) beyond this the spacing was spread to 0.32 kilometer $(0.2 \mathrm{mile})$, and finally $0.8 \mathrm{kilometer}(0.5 \mathrm{mile})$ for a total straight line of 16 kilometers (10 miles). Gravity was tied to the Portland State University base station. In the field, the stations were tied to a station at the Spitzenberg junction approximately every two hours. This allowed a drift curve for the gravimeter to be established. Three readings were taken at each station and averaged. The station locations and elevations were surveyed using a theodolite and stadia rods and tied at the eastern end to benchmark E204 (USC\&GS) at the Yankton school yard. No other benchmarks were available along the line or at the western end to tie into (Figure 2). Gravity data is in 
Appendix A.

The Apiary line crossed two strong lineaments, the Clatskanie River - Shaffer Road and the Little clatskanie River (Figure 2). Due to the wider area to be covered the gravity stations were spaced at 0.32 kilometer ( 0.2 mile) for about $10 \mathrm{kilometers}(6.3$ miles $)$ across the lineament zone, widening to 0.8 kilometer $(0.5 \mathrm{mile})$ for 5 kilometers ( 3 miles) on either side of the zone, and 1.6 kilometers (1 mile) apart at the east end for a straight line of 24 kilometers ( 15 miles). This line was read in several segments; each segment tied to the Portland State University base station, and the field stations were tied to an anchor station on the line every two hours to establish gravimeter drift. The station locations were surveyed with a theodolite and stadia rods, and one section with an Electronic Distance Meter (EDM), to establish elevations. The surveying was tied on the eastern end to benchmark V305 (OSHD) at the bridge over Tide Creek on U.S. Highway 30. No benchmarks were available along the line or near the west end, however the west end intersection map elevation was used as a crude guide and agreed with the surveyed elevation (Figure 2).

On the Pittsburg-Yankton line, gravity was read at established benchmarks only. The purpose of this line was to fill in between the Spitzenberg and Apiary lines and more frequent readings were not deemed necessary. The line was tied to the Portland State University base station but 
intermediate repeated readings at a station on the line were not made. The line was tied to benchmark E204 (USC\&GS) at Yankton school on the east end, and benchmark A205 (USC\&GS) at the bridge over the east fork of the Nehalem River on Highway 47 on the west end. The straight line length is 21 kilometers (13 miles) (Figure 2).

Regional Trend

Complete Bouguer gravity anomaly values in northwestern Oregon generally decrease from zero at the Oregon Coast to -80 to -100 at the Cascade Range (Bromery and Snavely, 1964; Berg and Thiruvathukal, 1976b). There is a high over the Tillamook Highlands (+60 mgal), a low in the Tualatin Valley (-60 mgal), and a fairly steep north - south trending gradient from Longview, Washington, through central and western Columbia County, western Washington County and continuing south. A high from the Willapa Hills of southwestern Washington projects into northern Columbia County near Clatskanie (Figure 9).

The Apiary and Pittsburg-Yankton lines cross the eastern part of the north - south gradient, and the Spitzenberg line is in an area of constant anomaly. Regional anomaly values across the gravity lines range from $-15 \mathrm{mgal}$ to $-38 \mathrm{mgal}$. The complete Bouguer gravity anomaly contours from this study's data are discussed in the chapter on Modelling. 


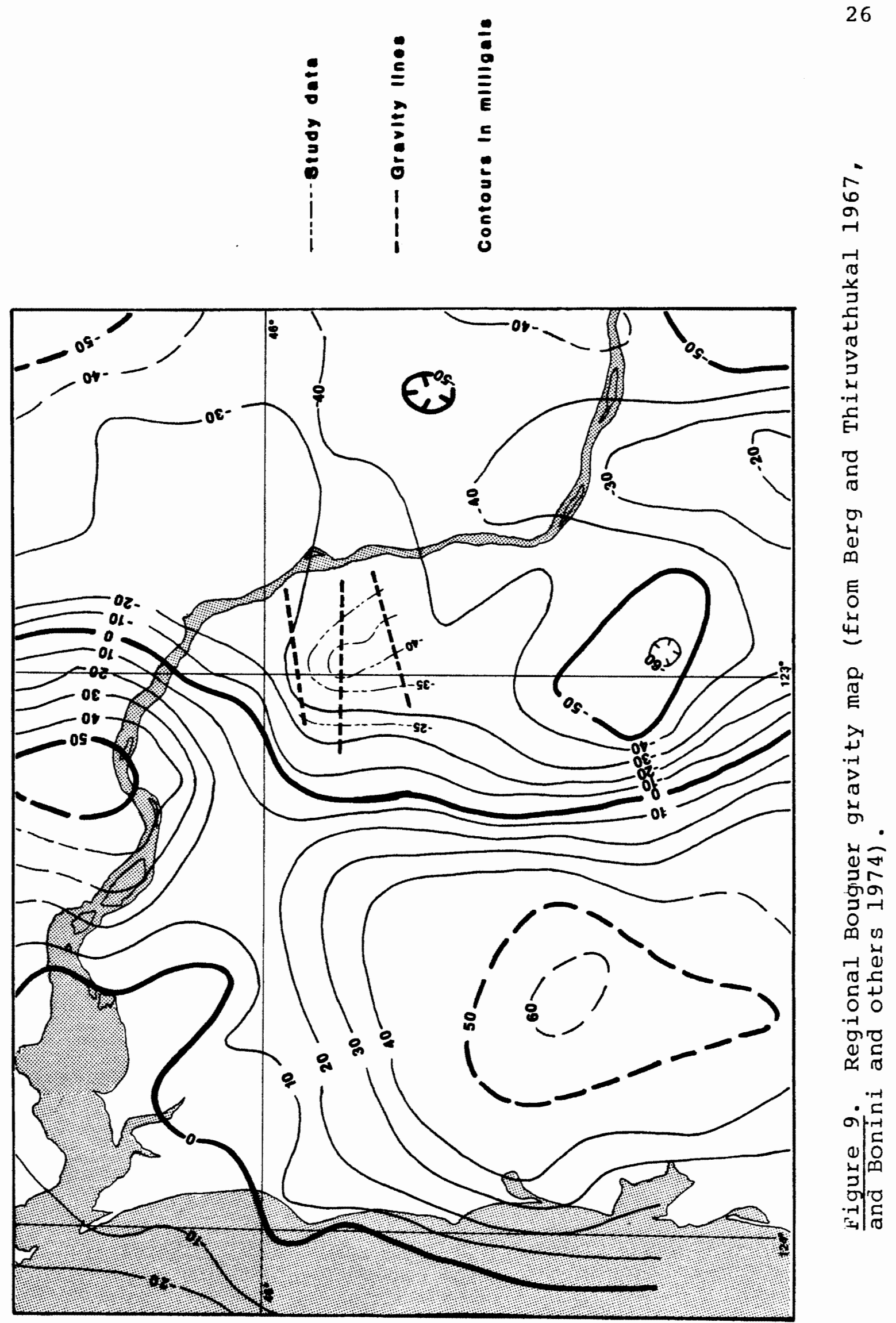


Data Reduction

Gravity readings must be corrected for 1) instrument drift, 2) earth tides (due to the gravitational attraction of the sun and moon), 3) latitude, 4) elevation, and 5) the surrounding terrain. The distance from the equator (latitude) must be corrected for since the earth is a rotating ellipsoid, bulging at the equator, which results in the attraction of gravity increasing toward the poles. The elevation correction is composed of two parts, free-air and Bouguer. The free-air correction accounts for the differences in gravity due to changes in elevation. The surveyed elevations and a sea level datum were used. Differences in mass between the gravity station and sea level are accounted for by the Bouguer correction. A density of $2.67 \mathrm{~g} / \mathrm{cm}^{3}$ was used for the Bouguer correction to correct for the mass between the station and sea level. Terrain corrections compensate for the decreased gravitational attraction due to hills above the station pulling upward and the decreased gravitational attraction due to valleys (lack of mass) surrounding the gravity stations. This correction was done with Hammer charts, by hand for rings $C$ through $G$, using $7 \frac{1}{2}{ }^{\prime}$ topographic maps and tables in Dobrin (1960), corrected for $2.67 \mathrm{~g} / \mathrm{cm}^{3}$ density. Terrain corrections from ring $\mathrm{H}$ out to 167 kilometers were done by computer by Northwest Geophysical Associates. Elevations for gravity stations were taken from the topographic maps. Standard correction formulas from Telford and others (1976) and Dobrin (1960), 
and the computer program used to determine station elevation from survey data, are in Appendix A. Gravity meter readings are convertible to relative gravity but must be referenced to a known base station to obtain observed gravity values. The base station established at Portland State University's Geology Department office is the reference with an absolute gravity of $980641.35 \mathrm{mgal}$. Most corrections to gravity data were done by computer by Northwest Geophysical Associates.

\section{Equipment Used}

Worden Gravity Meter, Model III (Master), No. 575; sensitivity - .10374 mgal/scale division (loaned by Oregon State University). Wild T2 theodolite.

Topcon DMS-1 Electronic Distance Meter (rented). Stadia rods (Philadelphia rods).

\section{REFRACTION}

\section{$\underline{\text { Purpose }}$}

Seismic refraction lines were run across the lineaments to look for near surface ( 0 to 60 meters) evidence of faulting. Displacements may not be visible on the surface but if there had been recent activity on the faults displacements of sediments and basalt should be evident at shallow depths. Cross-sections drawn from the time-distance curves would show any near-surface faulting. 
Field Procedure

Refraction lines were run on isolated dirt or gravel roads as close to the gravity lines as possible. This eliminated vehicle noise and vibration, and in most instances avoided road fill. The locations of the three lines are shown in Figures 2,10 and 12 , and described in the Location section. The refraction lines were reversed. The energy source was a 300 or 500 pound weight dropped from the Oregon State University thumper tripod a distance of about three meters (nine feet) onto a steel plate on the ground. The Bunker Hill Road line is about 4.5 kilometers $(2.8$ miles) northwest of the spitzenberg junction and 3.5 kilometers $(2.2$ miles $)$ southeast of the wilark junction on the Pittsburg-Yankton line (Figures 2 and 10).

Bunker Hill Road is a dirt road without a rock base. The refraction line runs 2200 feet (670.6 meters) east and west of the Bunker Hill Road - Wilark 247 Road junction, along Bunker Hill Road, for a total length of 4400 feet (1341 meters). One line of 12 geophones was run with 20 foot ( 6.1 meter) phone spacing to determine the velocity of the weathered or surface layer. The rest of the reversed lines had 50 foot (15.2 meter) geophone spacing and were shot with double coverage at the 1100 foot (335.3 meter) distances. Figure 11 shows a typical layout. A 300 pound weight was used for 550 foot ( 167.6 meter) lines and a 500 pound weight for the 1100 foot ( 335.3 meter) lines. 


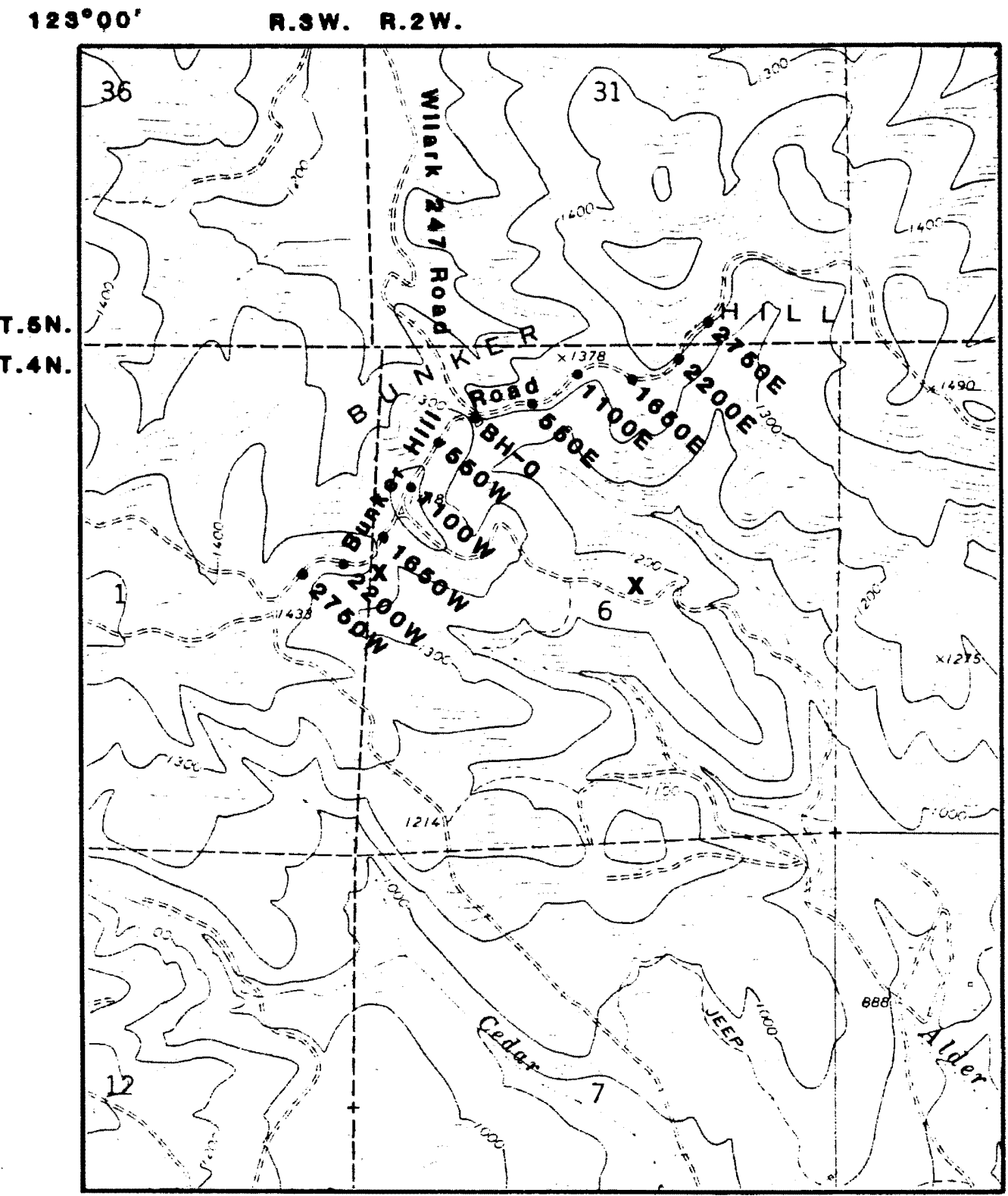

- Refrection station

$x$ Water well (approx.)

Figure 10. Bunker Hill refraction line (from USGS $\left.7 \frac{1}{2}\right)^{\prime}$ Chapman quadrangle map, 1971). 

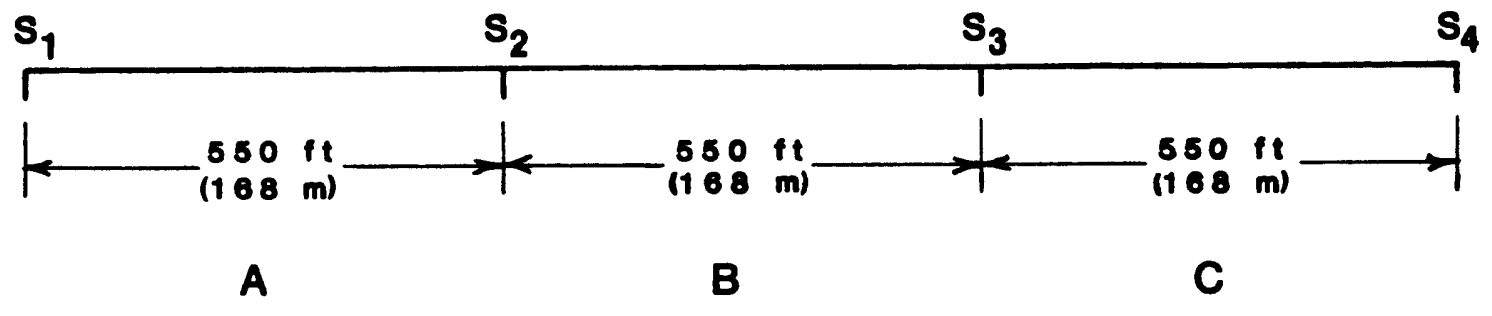

Figure 11. Typical refraction line layout.

For example, line $A$ was thumped with 300 pounds at $S_{1}$ and $S_{2}$, line $B$ with 300 pounds at $S_{2}$ and $S_{3}$ and line $C$ with 300 pounds at $S_{3}$ and $S_{4}$. The 1100 foot ( 335.3 meter) line $A B$ was thumped with 500 pounds at $S_{1}$ with geophones at $B$ and with 500 pounds at $S_{3}$ with geophones at $A$. The line BC was similarily thumped at $\mathrm{S}_{2}$ and $\mathrm{S}_{4}$, so the $\mathrm{B}$ section is covered twice. This continued down the total length of the line. The refraction data for this line is in Appendix B. The Shaffer Road line parallels (within 0.1 mile) the Apiary-Oak Ranch Road for approximately 3800 feet (1158 meters), then follows the Apiary Road east for another 600 feet (183 meters) from the Shaffer Road - Apiary Road junction (Figures 2 and 12). One line with 20 foot (6.1 meter) geophone spacing was run to determine the surface layer velocity. The entire 4400 foot (1341 meter) line was run with 50 foot ( 15.2 meter) spacing in the same manner as the Bunker Hill line, however two sections of 1100 foot (335.3 meter) line were not reversed due to operator error. 
R.3 W.

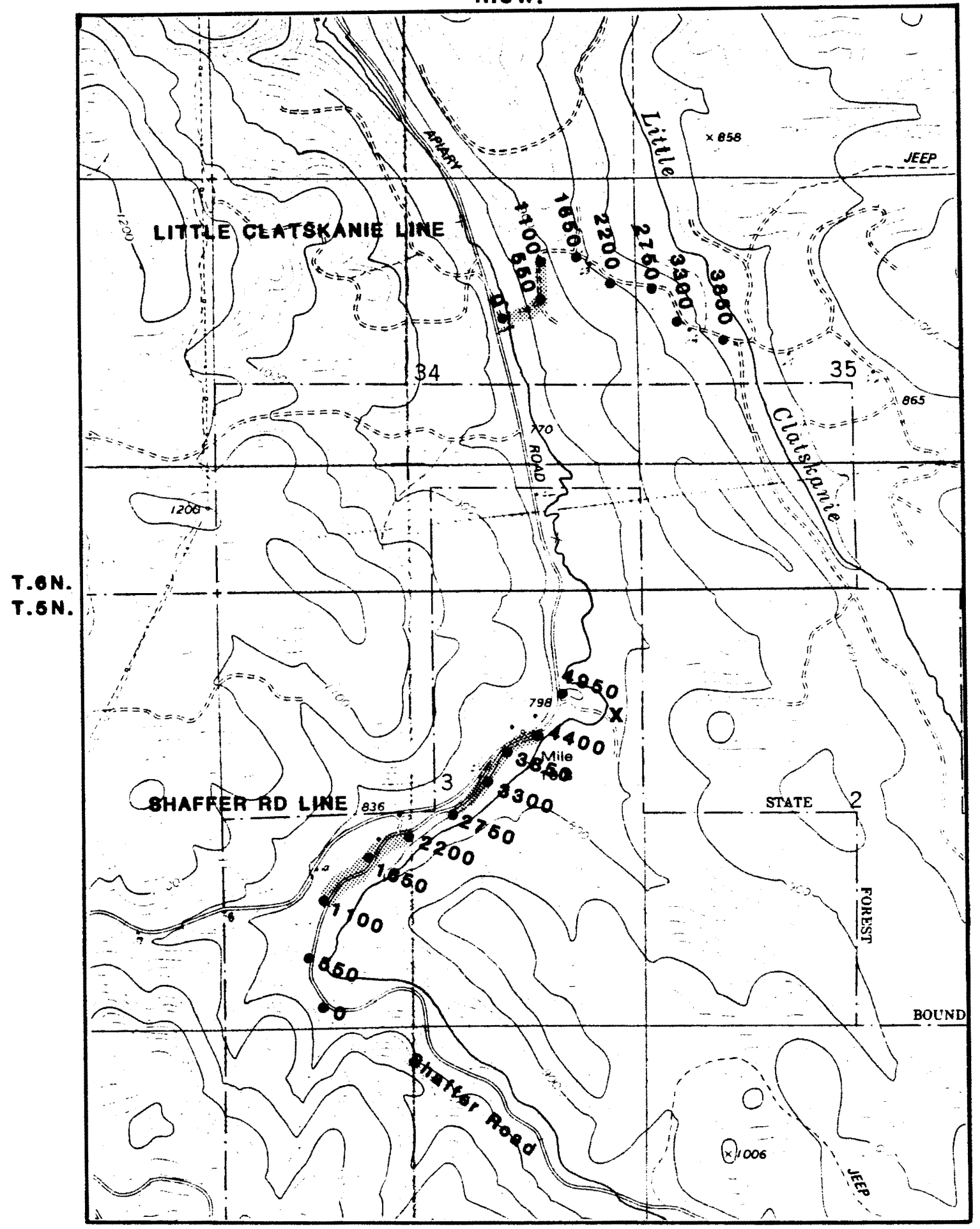

Area of high energy attenuation

- Refraction station

$x$ Water well (approx.)

Figure 12. Shaffer Road and Little Clatskanie River Road refraction lines (from USGS $7 \frac{1}{2}{ }^{\prime}$ Baker Point quadrangle map, 1979). 
They were not shot at a later time because the 1100 foot (335.3 meter) records were so poor on this line that it was felt no additional information would be gained from them. Shaffer Road is gravelled and the Apiary Road is paved. The refraction data for this line is in Appendix $B$.

The Shaffer Road line could not extend across the entire Clatskanie River - Little Clatskanie River lineament zone because of restricted access, so a section was offset north 1.5 miles $(2.4$ kilometers) and continued east for 3300 feet (915 meters) along the Little Clatskanie River Road, which is a gravelled logging road. The technique was the same as the other lines except that no line with 20 foot (6.1 meter) spacing was run (Figures 2 and 12). The refraction data for this line is in Appendix B.

\section{Data Reduction}

The first break of each geophone trace on a record was picked and the time vs. distance graphed. (The seismic record has time lines spaced $100 \mathrm{~ms}$ apart). Straight line segments were fitted to the data points, and the velocities, depths, and dips for the different layers determined by standard formulas in Dobrin (1960), Nettleton (1940), Ewing and others (1939), Mota (1954) and Heiland (1968). Corrections for elevation changes along the lines were made according to Nettleton (1940, p.266). Formulas used are shown in Appendix B, with the data. 
Equipment Used

SIE recording amplifier, Model RA-44, 12 channels.

SIE recording oscillograph, Model R-4.

Mark Products $7 \frac{1}{2} \mathrm{~Hz}$ geophones.

Thumper trailer with 300 pound and 500 pound weights,

loaned by Oregon State University.

\section{MAGNETICS}

\section{Purpose}

Magnetics lines were run to complement the nearsurface refraction data. The different magnetic susceptibilities of basalt and sediments should be evident if faulting has displaced blocks of either type of rock. These anomalies should show up in a cross section drawn from magnetic anomaly data.

\section{Field Procedure}

A magnetic survey was run along the same lines as refraction. Readings were taken every 30.5 meters (100 feet) with a total field nuclear precession magnetometer. The distances were paced. Readings were repeated at each station three times, or until three readings were obtained with no more than one gamma variation. A station at the center of the line was read at the beginning and end to establish drift. 
Data Reduction

The readings at each station were averaged and plotted against distance, at the same distance scale as the refraction plots (See figures 26,28 and 30 ). No drift corrections were made since total variations over an entire day were no more than 20 gammas. No other corrections were made. Data is in Appendix $\mathrm{C}$.

Equipment Used

Geometrics G816 Magnetometer. 
MODELLING AND RESULTS

The three types of geophysical data have been modelled and interpreted separately. They are compared and integrated in the section on Discussion and Conclusions.

\section{GRAVITY}

\section{General}

The gravity method measures differences in the earth's gravitational acceleration. Differences in the measured values, after corrections, indicate lateral changes in the densities of the subsurface rocks. The acceleration of gravity at the earth's surface is about $980 \mathrm{~cm} / \mathrm{s}^{2}$ or 980,000 milligals. Variations as small as one part in $10^{8}$ are measured in gravity prospecting. Interpretation of gravity data requires some familiarily with the regional geology which can be used to establish "reasonable" limits on possible depths and density contrasts. Since the anomalies (variations in density) of interest in the study area are near-surface and partly above sea level, all modelling and most interpretation has been done with the free-air anomaly values.

Determination of the density of subsurface rocks is difficult and may vary within a formation or type of rock. Thus a density of $2.8-2.9 \mathrm{~g} / \mathrm{cm}^{3}$ for basalt is the average 
of a range from 2.7 to $3.3 \mathrm{~g} / \mathrm{cm}^{3}$, although the values within one formation would not necessarily vary this amount. Variables affecting the density ranges for igneous and sedimentary rocks include grain type, size, shape and sorting, depth of burial, age, and porosity. Weathering usually lowers the density of rocks. The density of igneous rocks increases with a decrease in silica content, for example, rhyolite averages $2.5 \mathrm{~g} / \mathrm{cm}^{3}$ and basalt averages $2.9 \mathrm{~g} / \mathrm{cm}^{3}$. For gravity modelling in this study, the following density averages have been assumed: basalt $2.8-3.0 \mathrm{~g} / \mathrm{cm}^{3}$, post Eocene sediments $2.4 \mathrm{~g} / \mathrm{cm}^{3}$, Eocene sediments and interbedded volcanics $2.5 \mathrm{~g} / \mathrm{cm}^{3}$, silicic volcanics $2.3-2.6 \mathrm{~g} / \mathrm{cm}^{3}$ (Snavely and Wagner, 1964; Hammond, 1980; Telford and others, 1976), alluvium, unconsolidated sand and gravel $2.0 \mathrm{~g} / \mathrm{cm}^{3}$ (Heiland, 1968; Telford and others, 1976). These values are similar to those used by Pfaff (1981), Jones (1977) and Perttu (1980).

Assumptions made in modelling include 1) the "average" density is representative of the rock type or formation, 2) gravity can be modelled in two dimensions, i.e., modelled as two dimensional blocks with the third dimension infinite, 3) the "regional" values from very deep structures do not mask local anomalies, and have not been removed. Modelling was not extended deeper than six kilometers since there is no geologic information readily available that would allow reasonable assumptions of rock type below that depth. 
Modelling was done on the Portland State University Honeywell computer using the program FREEAIR. This program was adapted from Oregon State University programs by Terry Jones (1977). A program listing is included in Appendix A. Regional Models

The trends of the Apiary and Spitzenberg gravity lines were extended approximately 75 kilometers (47 miles) west (to the Oregon coast) and 100 kilometers (63 miles) east (to the vicinity of Swift Reservoir) (Figure 13) to allow regional modelling and eliminate any influence of the edge of the model on the actual gravity lines being studied. The "edge effect" is the effect of the density contrast between the model and air at the ends. This has an overwhelming influence on the anomaly amplitude since it is a contrast of $2.4-2.8 \mathrm{~g} / \mathrm{cm}^{3}$ (to zero for air), compared with density contrasts of $0.2-0.5 \mathrm{~g} / \mathrm{cm}^{3}$ within the model. Oregon freeair gravity values were taken from the Free-Air Gravity Anomaly Map of Oregon (Berg and Thiruvathukal, 1967a). Free-air values for Washington were not available so complete Bouguer values (Bonini and others, 1974) were used with the Bouguer correction added back into the anomaly values. Elevations were determined from a 1:500,000 topographic map. These free-air values are only approximate but adequate for the general regional model. Modelling was begun using known densities, depths and locations of formations and available cross sections and well data. 


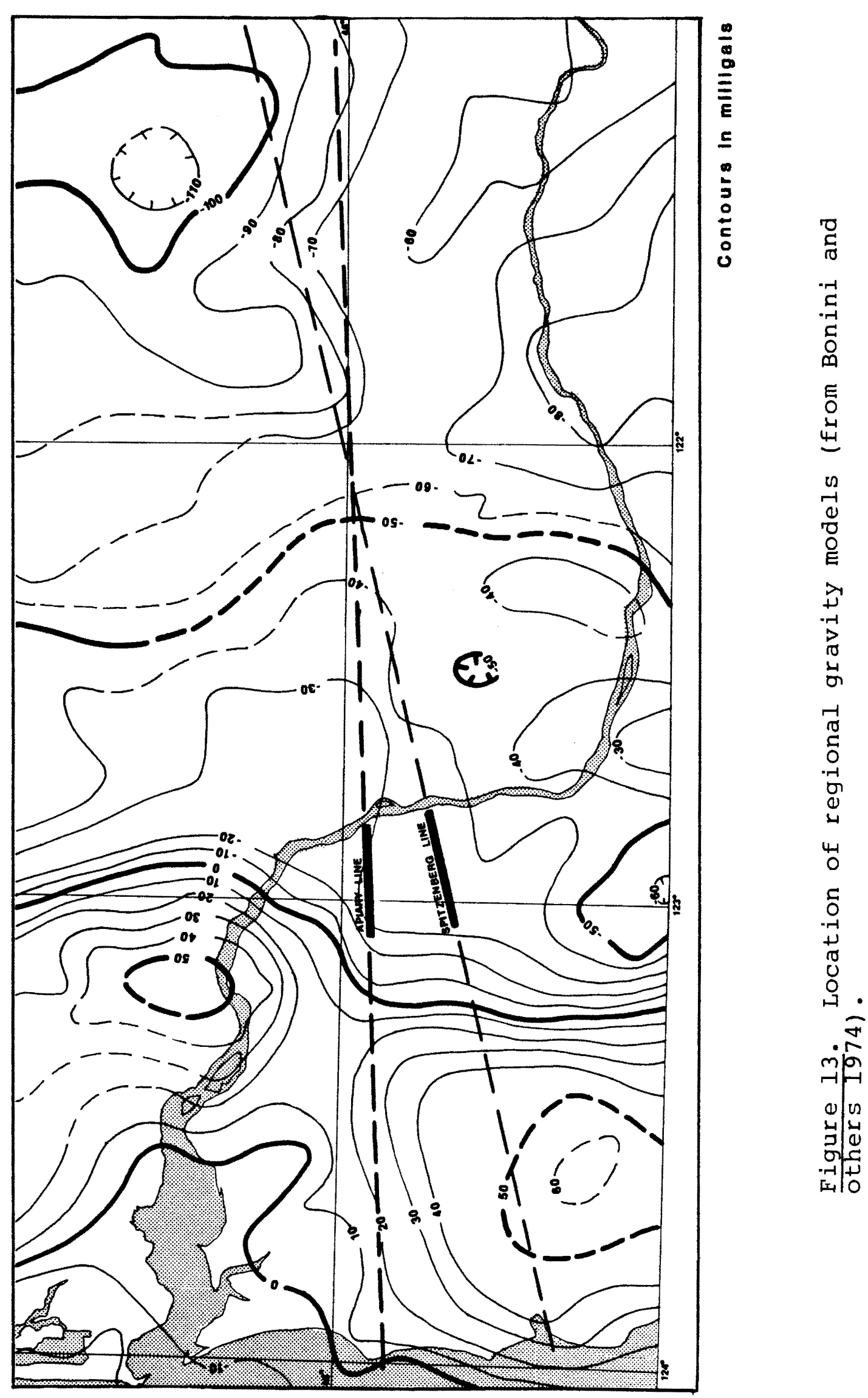


The Apiary regional free-air gravity model (Figure 14) has approximately one kilometer (3000 feet) of $2.4 \mathrm{~g} / \mathrm{cm}^{3}$ sediments on top of $2.8 \mathrm{~g} / \mathrm{cm}^{3}$ igneous rocks, probably basalt, in the west. The Nehalem Valley to Lake Merwin section of the model consists of 600 meters (1800 feet) of $2.4 \mathrm{~g} / \mathrm{cm}^{3}$ sediments above $2.5 \mathrm{~g} / \mathrm{cm}^{3}$ sediments, with a block of 2.7 $\mathrm{g} / \mathrm{cm}^{3}$ rock, probably igneous, about four kilometers $(12,200$ feet) deep at the east side. The Washington Cascade volcanics model as a block of $2.3 \mathrm{~g} / \mathrm{cm}^{3}$ material $1.5 \mathrm{kilometers}$ (4575 feet) deep, with $2.5 \mathrm{~g} / \mathrm{cm}^{3}$ material below it. The $2.4 \mathrm{~g} / \mathrm{cm}^{3}$ sediments in the western and central sections are the post Eocene Keasey, Pittsburg Bluff and Scappoose Formations, above Tillamook Highlands volcanic rocks on the west, and above Cowlitz Formation in the central section. The block of $2.7 \mathrm{~g} / \mathrm{cm}^{3}$ material may be Goble Volcanics or a local eruptive center of similar age. This block was necessary to bring the model into agreement with the regional anomaly values (Figure 14). The Washington Cascades area is less well known stratigraphically but the $2.3 \mathrm{~g} / \mathrm{cm}^{3}$ and $2.5 \mathrm{~g} / \mathrm{cm}^{3}$ values fit the brecciated, tuffaceous and volcaniclastic nature of the ohanapecosh Formation. Rock types below this formation are not known but model with a similar density of $2.5 \mathrm{~g} / \mathrm{cm}^{3}$.

The Spitzenberg regional free-air gravity model is generally similar to the Apiary regional model (Figure 15). The Tillamook Highlands in the west have no sediments on top, and the igneous rocks model with a density of $2.9 \mathrm{~g} / \mathrm{cm}^{3}$. 


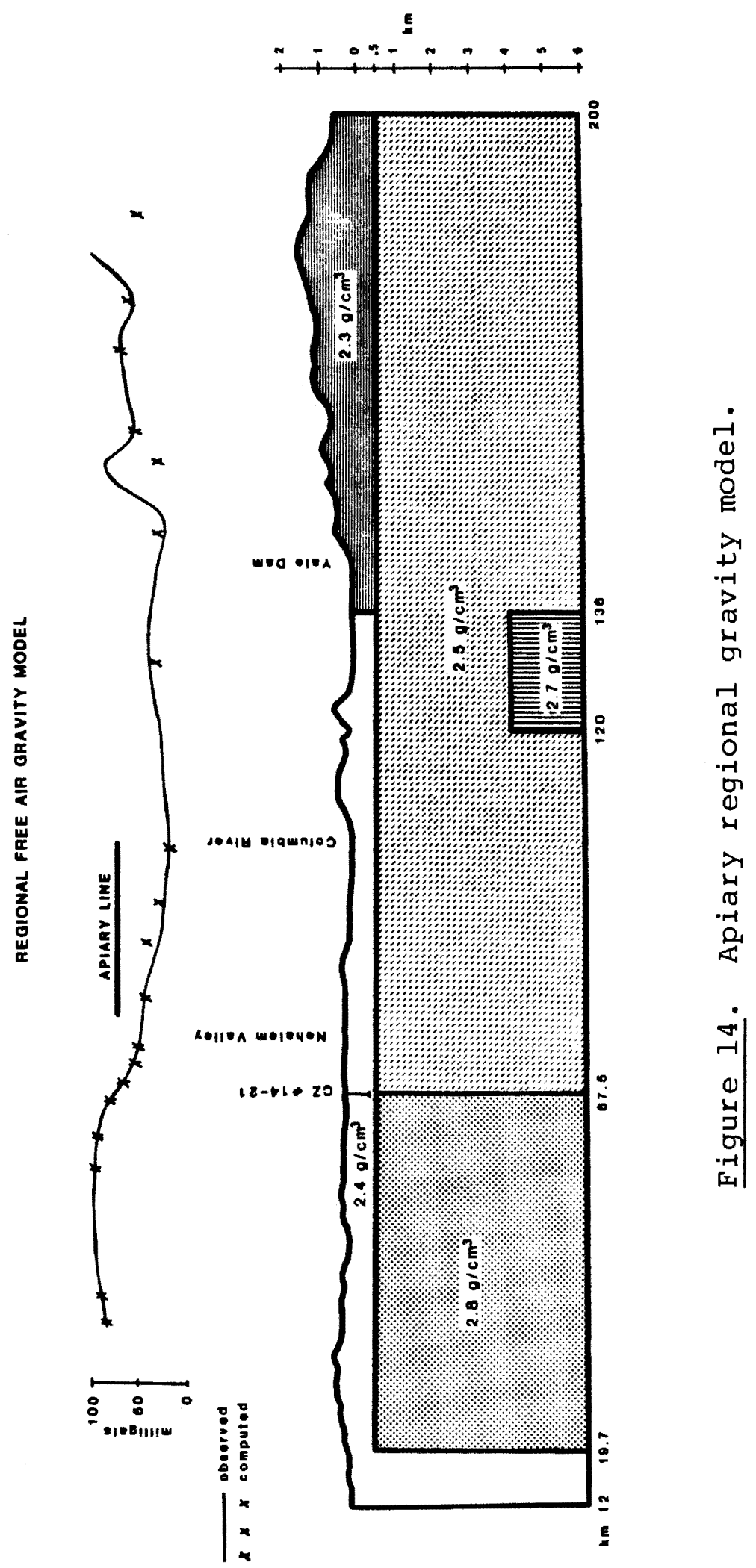




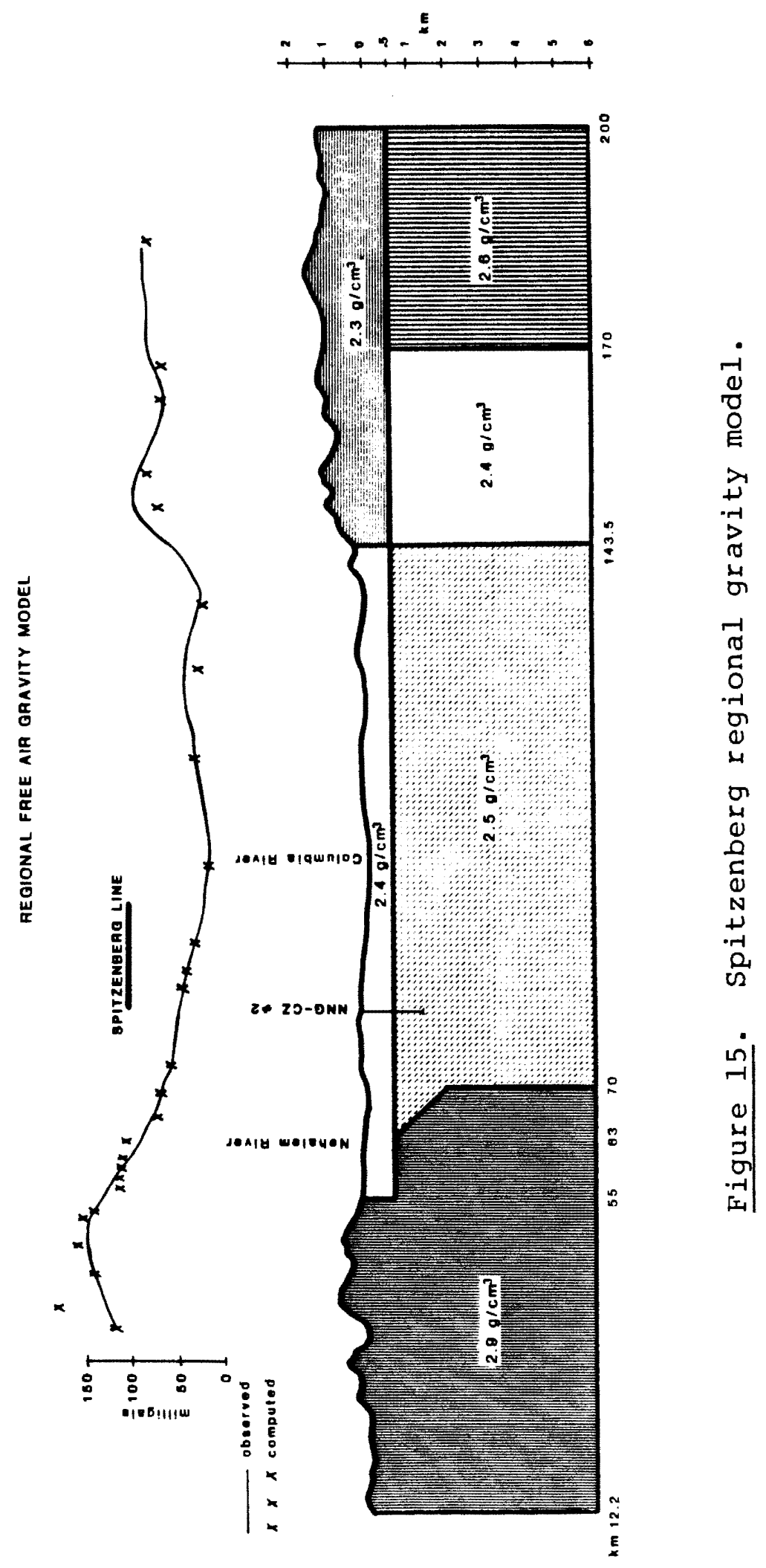


Sediments lap onto the igneous rocks on the east side of the Tillamook Highlands and continue across the center section. Onlap of both Eocene (Cowlitz) and post Eocene sediments was necessary for the model to fit. The eastern section of the model, in the Washington Cascades, is again lower density volcanics with those below increasing in density to the east. The deeper $2.7 \mathrm{~g} / \mathrm{cm}^{3}$ block in the central section of the Apiary model is not necessary to model this line.

The regional view for both models is quite similar, especially in the sections where the local gravity lines were run, indicating that differences between the local lines are due to near-surface contrasts and not an abrupt, deep-seated, area wide change. Both lines appear to be in deep sediments at the edge of the Tillamook Highlands. Pfaff's (1981) gravity models across the coast Range are similar to the models used here.

Local Models

Modelling of the local lines began with the addition of the measured gravity values to the regional values, and reduction of the area modelled to slightly larger than the measured line itself. The regional model was used at first and changes made to bring the model into agreement with the observed free-air gravity anomaly values. The local changes should not affect the regional model extending out from the ends of the gravity lines if the regional models are reasonably correct. Locations of the Apiary and Spitzenberg 
gravity lines are shown in Figures 2 and 13.

The Apiary gravity line modelling began with a known block of Goble Volcanics on the east end, and observation of the location of surface outcrops of basalt and sediments along the line (Figure 16). The modelled blocks of basalt are quite irregular along their lower surfaces. Underlying sedimentary highs occur at 94.6 kilometers, 87 - 88 kilometers, and at 81 kilometers along the line. The thick, high density $\left(2.9-3.0 \mathrm{~g} / \mathrm{cm}^{3}\right)$ blocks required to model the west end of the line are an artifact caused by the nearby attraction of the Tillamook Highlands block to the southwest. Well data from about eight kilometers west of the end of the line indicate sediments at least 550 meters deep. Relatively accurate modelling can only be done east of 79 81 kilometers. A block of lower density material, about 100 meters ( 300 feet) deep, has been modelled from 88 - 89 kilometers, and may be weathered or less well consolidated sediments.

The Spitzenberg gravity line, when matched to the regional model, fit well in the west where sediments are seen in outcrop, but had a large anomaly at the center of the line (Figure 17). The anomaly at the east end modelled well with a basalt block thickening to the east. It thins somewhat in the center indicating a possible sedimentary high. The central anomaly was modelled with a block of low density $\left(2.0 \mathrm{~g} / \mathrm{cm}^{3}\right)$ material which extends thinly west along a stream valley. This block is about 700 meters (2100 feet) 


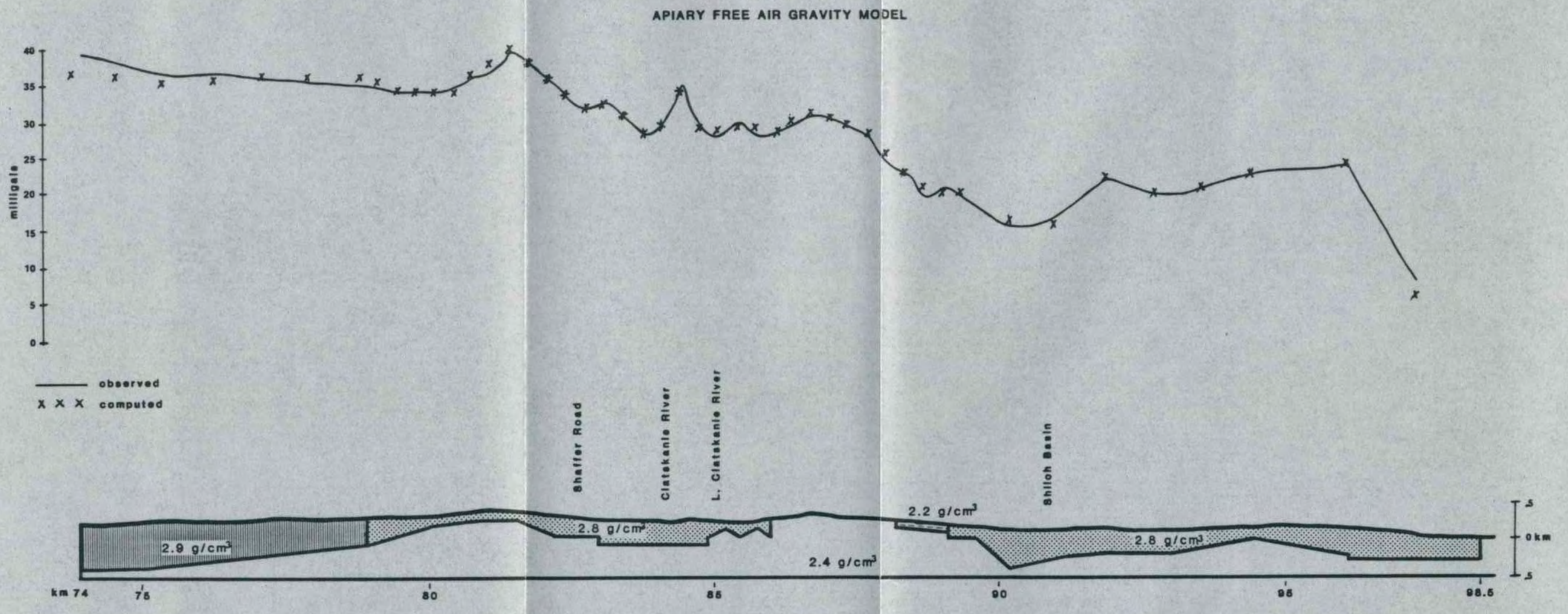

Figure 16. Apiary local gravity model. 


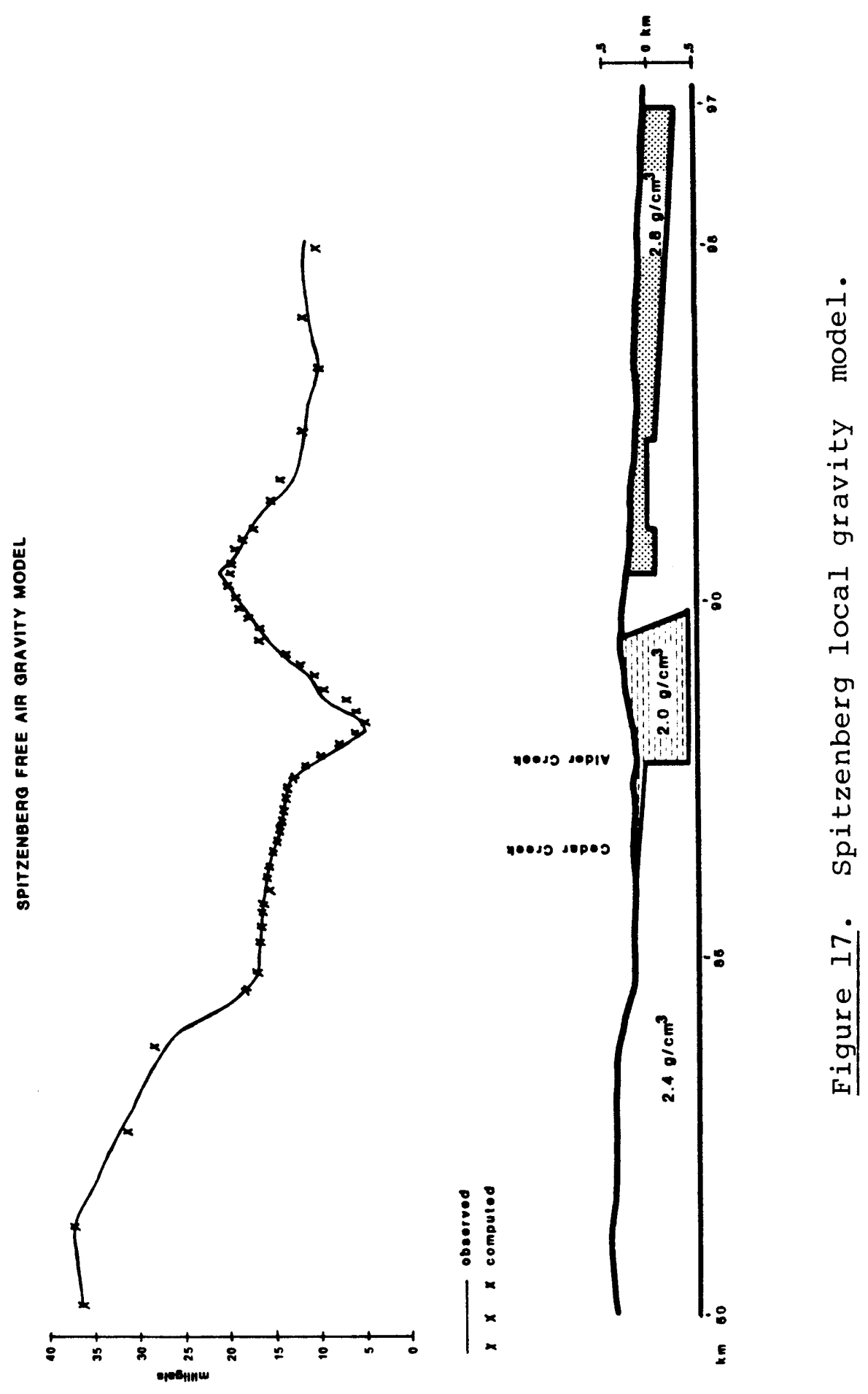


deep and two kilometers (6100 feet) wide. The low density material could be unconsolidated sand or clay, gravel, or some other poorly consolidated, or broken up, rock. It begins at the North Scappoose - Alder Creek lineament and extends east for two kilometers (6100 feet). This anomaly could also be modelled by a series of deeper and thinner blocks of the same material.

Comparison

Both the Apiary and Spitzenberg gravity models have blocks of $2.8 \mathrm{~g} / \mathrm{cm}^{3}$ density basalt in the eastern third of the model, thickening to the east. The thicknesses of the basalt blocks are similar with a more irregular lower surface on the Apiary model. Both lines generally fit the regional model of deep ( 6 kilometers) sediments in this area, but the central and western parts of each model differ. The Apiary model has sediments to the surface in the central part with a thin (200 - 300 meters) layer of $2.8 \mathrm{~g} / \mathrm{cm}^{3}$ basalt extending to the west. The spitzenberg line has a section of low density material in the center and sediments to the west. Both models indicate a sedimentary high, with basalt to the east, with more basalt deposited to the west in the north but not in the south.

A contour map of complete Bouguer gravity values (Figure 18) using the Apiary, Pittsburg-Yankton and Spitzenberg gravity data (Table I) indicates an area of higher gravity anomaly (more dense material) in an arc, 


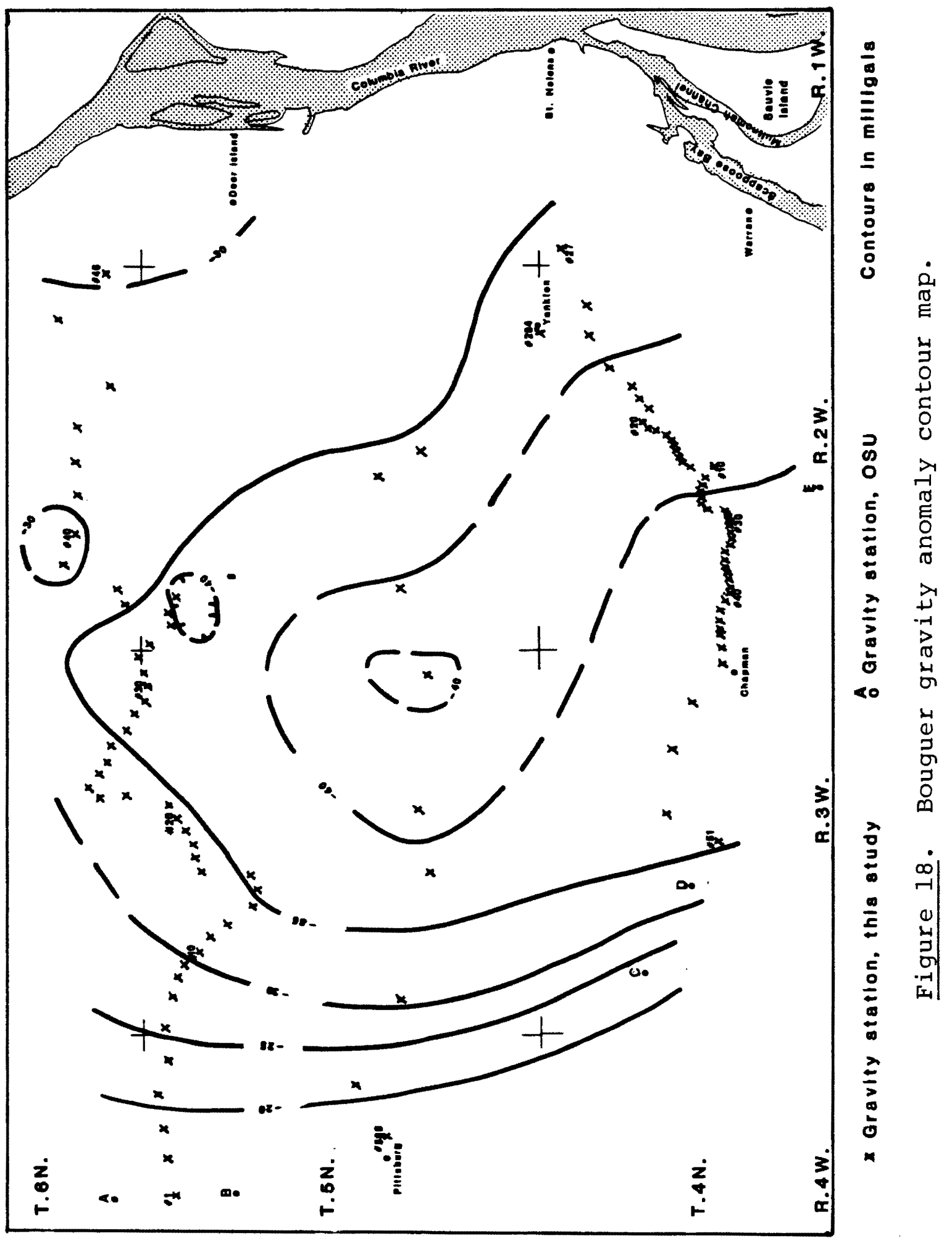



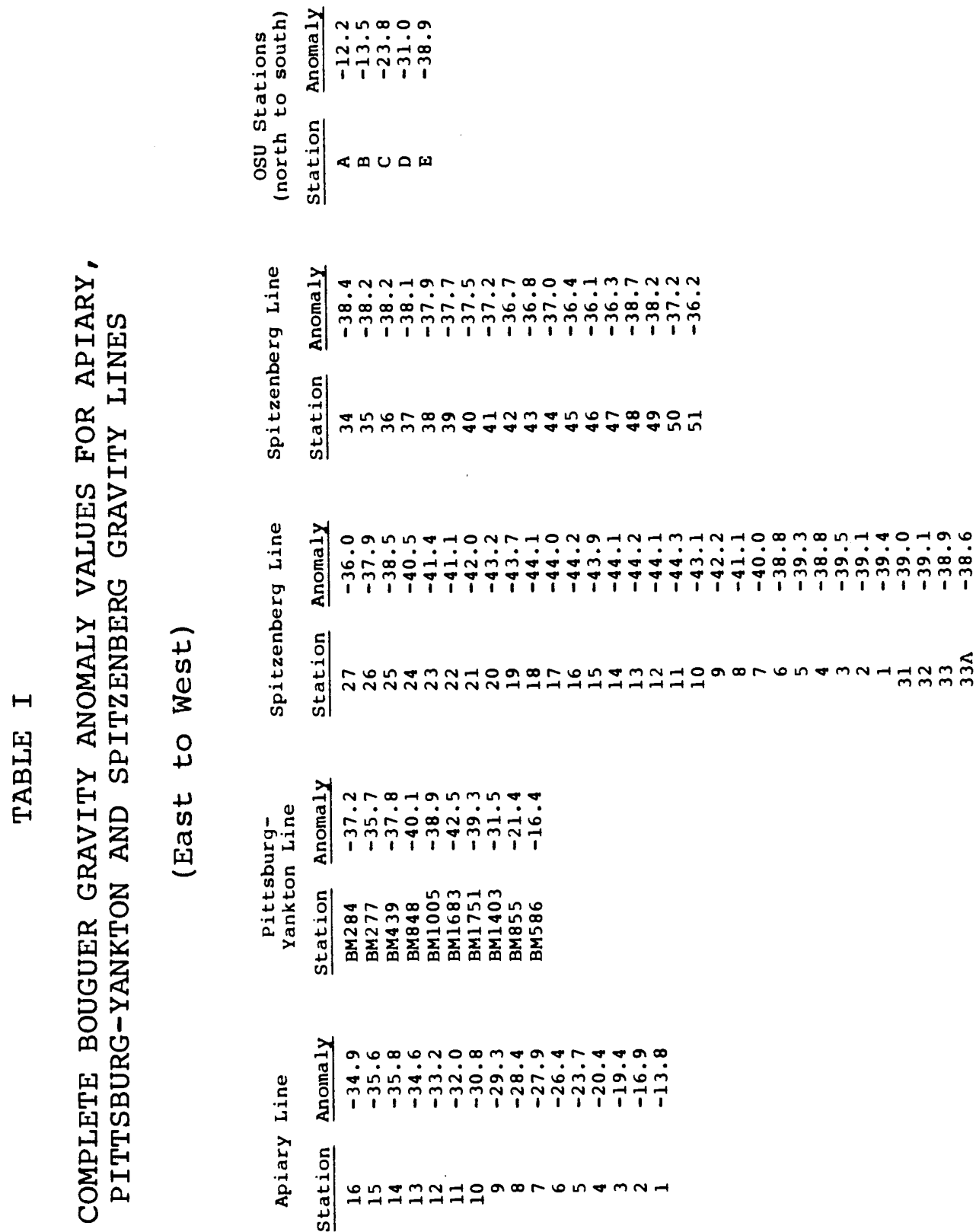

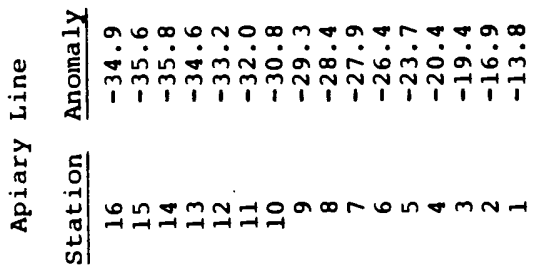

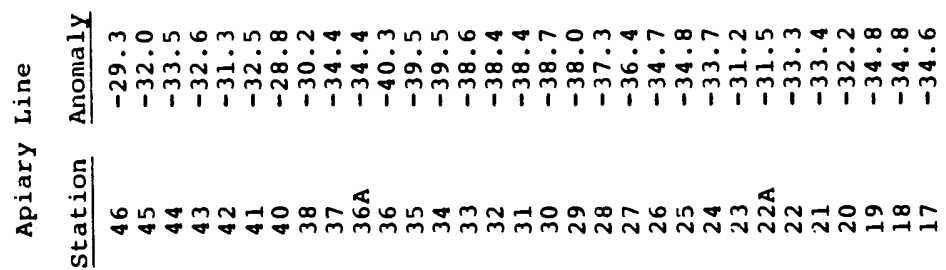


open to the south, around an area of lower gravity (less dense material). This gives an indication that there is a continuity of features which show up on the models, among the three gravity lines. Four gravity values on the western margin and one on the south edge were added from Oregon State University gravity data to make contouring more accurate.

\section{REFRACTION}

General

Interpretation of seismic refraction data is based on Fermat's principle that energy will travel from source to receiver along the path taking the least time, and snell's Law which states that the sine of the critical angle equals the ratio of the velocities of the materials on each side of an interface. Energy arriving at an interface at the critical angle will travel along the interface. This creates a disturbance in the upper medium generating waves which travel up through the upper medium at the critical angle. The time required for energy to travel from source to receiver gives information on the velocities and general structure of the materials beneath the surface (See formulas in Appendix B) .

Several assumptions, or boundary conditions, are made in refraction interpretation. 1) The velocity of each successively deeper layer of material is greater than the layer above it. 2) The velocity is constant within each 
layer (isotropic). 3) Each layer is sufficiently thick to be seen by refraction. 4) The interface between layers can be approximated by a plane.

Increasing velocity with depth is a necessary assumption since energy travelling from a faster to a slower layer will be refracted down through the slower layer. Thus a slower layer beneath a faster layer will not be seen in a time-distance plot, and the next high velocity layer will appear deeper than it really is. This assumption is reasonable since sediments compact with burial, and the deeper, less porous sediments will have a higher velocity than the shallower ones. Weathering also reduces velocity which results in an increase of velocity with depth. In the study area sediments lie above and below basalt. The sediments below the basalt generally will not show up on time-distance plots because they should have a slower velocity than the basalts.

Constant velocity within each layer is often not an accurate assumption. A linear increase of velocity with depth, as in sediments being compacted, will show on the time-distance plot as a curved line. Usually the average velocity over the interval being investigated is used and provides an adequate approximation of the actual conditions. Velocity may also vary laterally within a layer but is usually averaged out over the length of the total refraction line (Dobrin, 1976; Redpath, 1973). 
The minimum detectable thickness of a layer depends on the velocity and thickness of the layers above and below it. Thin layers of sediments or basalt will not show up on the time-distance plots. Redpath (1973) describes a procedure for determining this value. Well logs and bore hole data are indispensable here.

Many interfaces between layers are non-planar and surface irregularities in the interface affect the transmission of energy. High frequency energy (short wavelength) is absorbed faster than low frequency energy as distance from the source increases, and is scattered more by irregularities. This is seen as less distinct arrivals at greater distances from the source (Redpath, 1973). Large irregularities may produce a shadow, a gap of no arrivals in the seismic record (Dix, 1952).

Errors in refraction are due to three general causes: 1) incorrect reading of the data, 2) incorrect assumptions, 3) incorrect geologic interpretation (Northwood, 1967). Incorrect picking of first breaks leads to errors in depth and dip calculations, and is especially likely when velocity contrasts are less than 3 to $4(.75)$. Incorrect assumptions can be minimized by using all available data on the local geology and checking interpretations against bore hole data. In all cases in this study the simpler interpretation was given precedence to avoid over interpretation of the data. The depth to interface values shown on the cross sections are not exact. The depth values cover a range, due 
to different velocity readings in opposite directions for each layer and variations in velocity along the line. The final values chosen are within the calculated range and agree with a reasonable geologic interpretation along the refraction line. Similarly, location of faults or vertical offsets cannot be determined exactly and may vary laterally up to 33 meters (100 feet), the distance between three geophones. Refraction data is listed in Appendix B.

\section{Bunker Hill Line}

The Bunker Hill refraction line (Figure 10), 1340 meters long, was the "best behaved" of the three lines run. The first breaks were cleaner and the records were of better quality than Shaffer Road or Little Clatskanie River Road. On a purely subjective rating of $\mathrm{A}$ (excellent) to $\mathrm{F}$ (marginally usable), all but three of the records were $\mathrm{C}$ or better.

Three velocity layers were observed on the timedistance plots (Figure 19). The surface or "weathering" layer has a velocity of about $1000 \mathrm{~m} / \mathrm{s}(3300 \mathrm{f} / \mathrm{s})$. continuously along the line except for a section between $\mathrm{BH}-0$ and $1100 \mathrm{E}$ where it is approximately $520 \mathrm{~m} / \mathrm{s}(1700 \mathrm{f} / \mathrm{s})$. (Station numbers refer to distance in feet east and west of the Wilark 247 Road - Bunker Hill Road intersection.) The second layer averages $1675 \mathrm{~m} / \mathrm{s}(5500 \mathrm{f} / \mathrm{s})$ from $2200 \mathrm{~W}$ to $\mathrm{BH}-0$ but slows down to about $1525 \mathrm{~m} / \mathrm{s}(5000 \mathrm{f} / \mathrm{s})$ on the eastern half of the line. The third layer is composed of two parts, the slower part has a velocity of $2130-2440 \mathrm{~m} / \mathrm{s}(7000-$ 


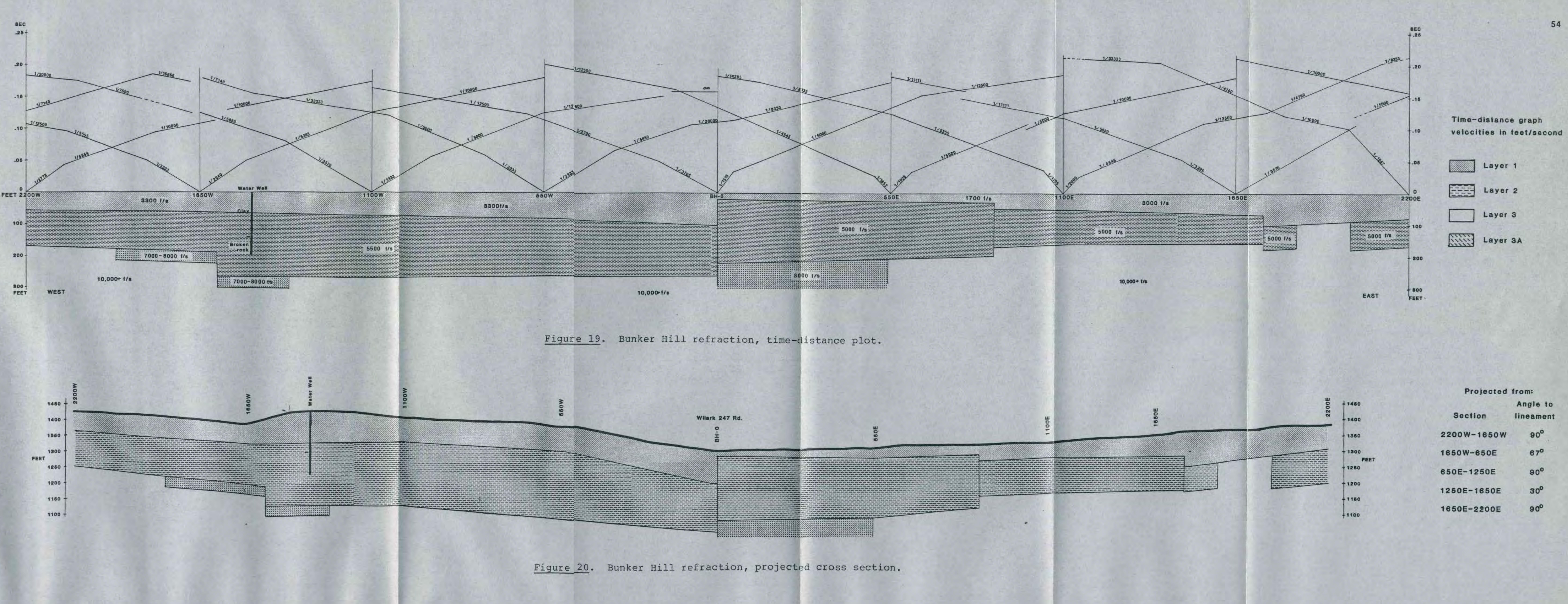


$8000 \mathrm{f} / \mathrm{s}$ ) and the faster part has a velocity of $3050 \mathrm{~m} / \mathrm{s}$ $(10,000 \mathrm{f} / \mathrm{s})$ and higher. The slower stratum is seen only in sections 2200W-1100W, BH-0-550E and 1650E-2200E. The high speed layer is continuous along the line.

The layer 1 - Layer 2 interface is basically flatlying with dips less than two degrees from 2200W-1100E, except in section 550W-BH-O (Figures 19 and 20). It dips about $6^{\circ}$ to the east in section $1100 \mathrm{E}-1650 \mathrm{E}$, and is faulted in section 1650E-2200E and at BH-0. The depth of this interface is about 18 meters (60 feet) at $2200 \mathrm{~W}$ and slopes gently to a depth of 30 meters (100 feet) at BH-0. The slower $(1525 \mathrm{~m} / \mathrm{s})$ layer 1 stratum is about 6 meters (20 feet) deep at $\mathrm{BH}-\mathrm{O}$ and slopes, with two vertical offsets, to about 24 meters $(80$ feet) at 2200E. The layer 2 - layer 3 interface has a discontinuity near $1650 \mathrm{E}$ and in section 550E1100E, and dips gently east from BH-0 to 550W. It is broken in several places in section 1650E-2200E. The depth of this interface varies from 52 meters (170 feet) at $2200 \mathrm{~W}$ to about 80 meters (260 feet) at BH-0, and 46 meters (150 feet) at $1100 \mathrm{E}$.

All outcrops along this line are red clay, suggesting that the refraction survey is seeing basalt in various stages of weathering. The logs from two water wells, one 0.8 kilometer $(0.5$ mile) south of the line $(T 4 N, R 2 W$, Sec. 6 , $\left.\mathrm{SW}^{\frac{1}{4}} \mathrm{NE} \frac{1}{4}\right)$, and one near the west end $\left(\mathrm{T} 4 \mathrm{~N}, \mathrm{R} 2 \mathrm{~W}, \mathrm{Sec}, 6, \mathrm{SW}^{\frac{1}{4}}\right.$ $\left.N^{\frac{1}{4}}\right)$ show 25 - 38 meters $(80-125$ feet) of clay above basalt 
or "broken rock" (Figure 10 and Appendix B). The velocity of clay is $915-1830 \mathrm{~m} / \mathrm{s}(3000-6000 \mathrm{f} / \mathrm{s})$, claystone about $1800 \mathrm{~m} / \mathrm{s}(5900 \mathrm{f} / \mathrm{s})$, fractured basalt $2745-4270 \mathrm{~m} / \mathrm{s}$ $(9000-14,000 \mathrm{f} / \mathrm{s})$, sandstone $1830-2440 \mathrm{~m} / \mathrm{s}(6000-8000$ $\mathrm{f} / \mathrm{s})$, and fresh basalt about $6100 \mathrm{~m} / \mathrm{s}(20,000 \mathrm{f} / \mathrm{s})$ (Redpath, 1973). Layer 1, with a velocity of $1000 \mathrm{~m} / \mathrm{s}(3300 \mathrm{f} / \mathrm{s})$ agrees well with clay while the section with a velocity of $520 \mathrm{~m} / \mathrm{s}(1700 \mathrm{f} / \mathrm{s})$ is more thoroughly weathered, contains some sandy clay, or is a layer of clayey topsoil. Soil that has been expanded by smectite has many air spaces and would give a very low velocity. Layer 2 , with a velocity of 1525 - $1675 \mathrm{~m} / \mathrm{s}(5000-5500 \mathrm{f} / \mathrm{s})$, is probably a more consolidated claystone or layer of very broken and weathered basalt. This broken, weathered basalt is seen in outcrop throughout the study area. The high speed layer 3 is fairly fresh basalt, with variations in velocity probably due to fractures and slight weathering near the top. The lower velocity layer 3 may be due to a vesicular area near the top of a basalt flow, a highly fractured layer, weathering or a sediment (sandstone) layer. This layer occurs only next to discontinuities on the Bunker Hill refraction line, but this does not hold for the other lines.

The major discontinuities have been modelled as faults. They are shown with vertical movement only due to the limitations of this refraction survey, but this should not be interpreted to mean the fault planes do not dip or 
that there is no horizontal component to the fault movement. It appears there are three faults along the Bunker Hill line, one near 1650W, one near BH-0 and a fault zone east of 1650E. Displacements cannot be modelled reliably, however the fault at $\mathrm{BH}-0$ has about the same vertical displacement as the one at $1650 \mathrm{w}$.

Shaffer Road Line

The Shaffer Road refraction line (Figure 12), 1340 meters (4400 feet) long, is rather complicated. The records are poorer than the other two lines, especially the 335 meter (1100 foot) sections. The seismic energy was absorbed very quickly (high attenuation), and in several sections first breaks were not seen beyond 245 meters ( 800 feet) from the source. On the $A$ to $F$ rating scale, $3 / 4$ of the records were $\mathrm{C}$ to $\mathrm{F}$.

Four layers were interpreted from the time-distance plots (Figure 21). A surface (weathered?) layer with a velocity of $1370-1657 \mathrm{~m} / \mathrm{s}(4500-5500 \mathrm{f} / \mathrm{s})$ is found in part of section 550-1100, near station 1100 and from 2200 3850. (Station numbers refer to the distance in feet from the west end of the refraction line.) From 2200 to 3850 the velocities vary from $730-1800 \mathrm{~m} / \mathrm{s}(2400-5900 \mathrm{f} / \mathrm{s})$ indicating significant anisotropy (lateral and vertical variation). Layer 2 , with a velocity of $2350-2530 \mathrm{~m} / \mathrm{s}$ $(7700$ - $8300 \mathrm{f} / \mathrm{s})$ may be a separate layer, or it may be a lower velocity zone at the top of layer 3 . It does seem to 


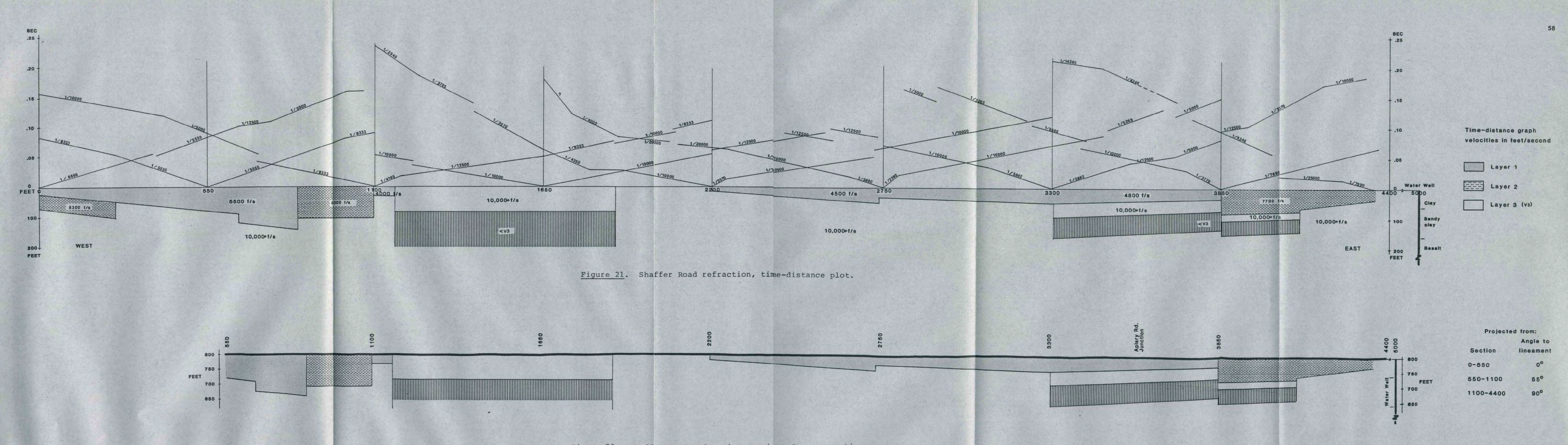


be separate on this line however, and occurs as blocks in sections $0-1100$ and $3850-4400$ only. Layer 3 is the high speed stratum with velocities of $3050 \mathrm{~m} / \mathrm{s}(10,000 \mathrm{f} / \mathrm{s})$ and higher, and is continuous along the line. A low velocity layer occurs below layer 3 discontinuously from 1100 to the east end of the line. Only surface waves arrive at receivers beyond 92 meters ( 300 feet) from the source in some sections.

Dips were difficult to determine for this line due to the many discontinuities in the records. The interfaces between layers generally appear to be flat or dipping less than $3^{\circ}$. More steeply dipping sections may occur in sections $550-1100$ and $3850-4400$ (Figures 21 and 22).

The Shaffer Road line is quite broken up. All nearby outcrops are basalt or clay suggesting that, like the Bunker Hill line, the different velocities indicate different stages of weathering of the basalt. A water well at the east

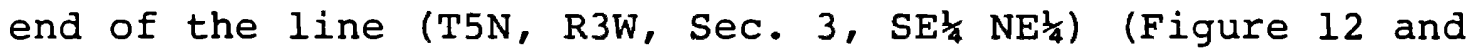
Appendix B) was drilled through 18 meters (60 feet) of clay, 30 meters (100 feet) of sandy clay, 92 meters (300 feet) of basalt, and bottomed in sandstone. In several places the time-distance plots indicate fresh basalt at the surface, and, except in section $550-1100$, the weathered surface layer is no deeper than 15 meters ( 50 feet). It was not possible to determine the depths of other layers or blocks. The low velocity layer beneath layer 3 may be an interflow weathered zone, a more weathered less competent flow, a 
vesicular zone, or sediments. There is no way to tell from the data available. The discontinuities have been modelled as faults. This line may cross two fault zones, or branches of the Shaffer Road - Clatskanie River lineament, since it is between two $90^{\circ}$ jogs in the Clatskanie River (Figure 23). This may help explain its broken and discontinuous nature. Here also the faults modelled with vertical movement may have other directional components but this refraction survey would not how them.

\section{Little Clatskanie River Road Line}

The Little Clatskanie River Road refraction line, located about 2.4 kilometers $(1.5$ miles) north of the Shaffer Road line, is an eastward continuation across the lineaments (Figure 12). It has a similar style and is 915 meters ( 3300 feet) in length. On the $A$ to $F$ rating scale $2 / 3$ of the records are $C$ to $F$.

The time-distance plots indicate three layers, with the fastest layer again having slow and fast strata (Figure 24). The surface (weathering?) layer velocity of $1370 \mathrm{~m} / \mathrm{s}(4500 \mathrm{f} / \mathrm{s})$ near the west end declines steadily to $915 \mathrm{~m} / \mathrm{s}(3000 \mathrm{f} / \mathrm{s})$ at the east end of the line. The second layer has a velocity of about $1740 \mathrm{~m} / \mathrm{s}(5700 \mathrm{f} / \mathrm{s})$ and appears at the surface in section 0-550. (Station numbers are distances in feet from the west end of the line.) It is seen as blocks in sections $1650-2200$ and $2200-2750$, then becomes continuous from 2750 east (Figures 24 and 25). The 


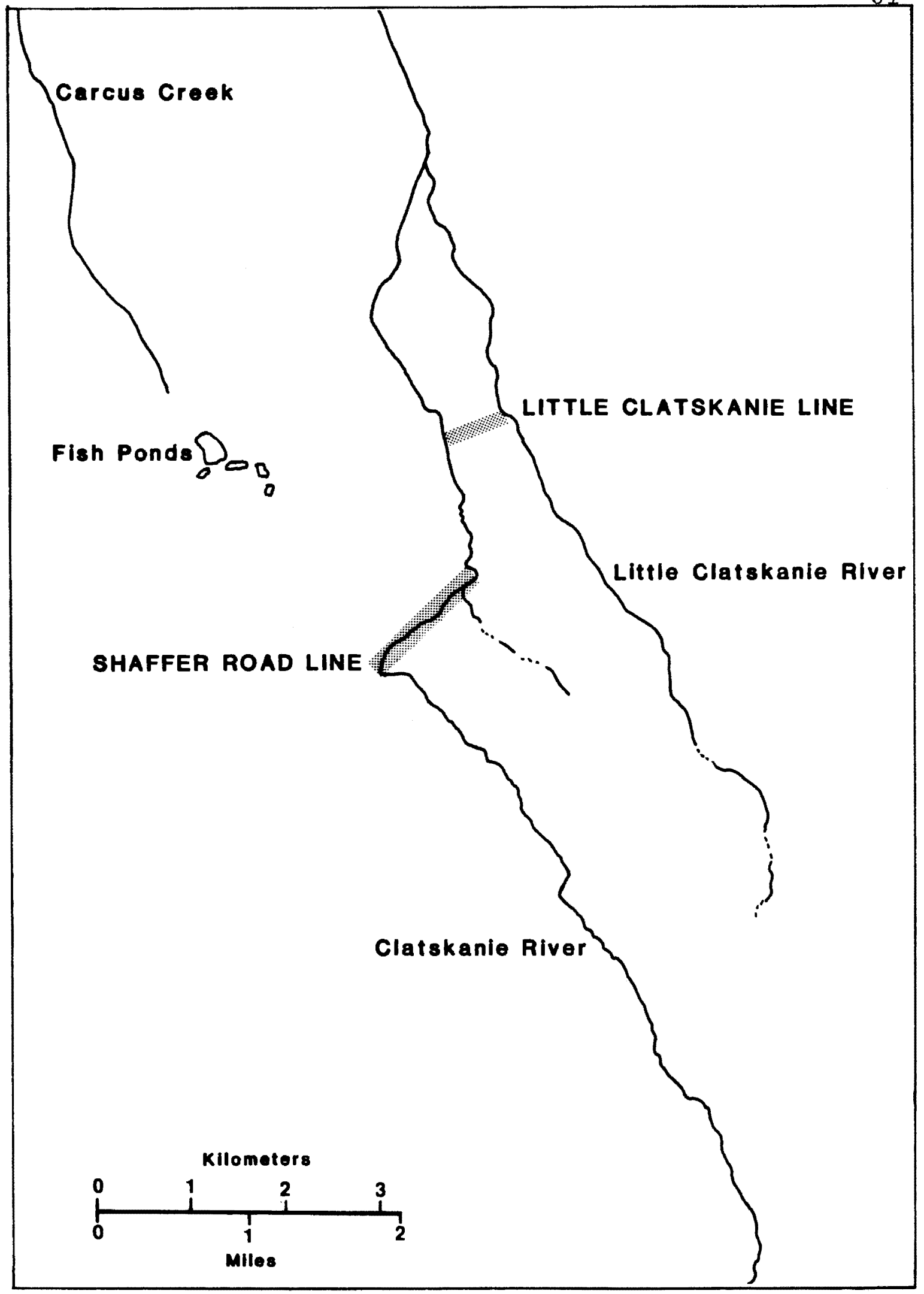

Figure 23. Lineament offset at north end of Shaffer Road. 





layer 3 fast stratum has velocities greater than $3050 \mathrm{~m} / \mathrm{s}$ $(10,000 \mathrm{f} / \mathrm{s})$, occurs at the surface in section $0-550$, and is continuous under the rest of the line. The slower part of the layer has velocities of $2380-2530 \mathrm{~m} / \mathrm{s}(7800-8300$ $\mathrm{f} / \mathrm{s}$ ) and occurs discontinuously along the line. A low velocity zone occurs beneath layer 3 in sections $0-550$ and $2200-2750$, and is indicated by the arrival of surface waves only at distances beyond about 180 meters (600 feet) from the energy source.

The dip on the layer 1 - layer 2 interface can be determined in only three sections and veries from $5^{\circ}$ to the east to $2^{\circ}-4^{\circ}$ to the west. All interfaces are assumed to be relatively flat-lying or with shallow dips similar to the other two lines. Layer 1 varies in depth from about 9 meters (30 feet) at 1100 to approximately 30 meters (100 feet) at 1650 and 2200, and is about 9 meters (30 feet) deep in section 2750 - 3300. The depth of the layer 2 - layer 3 interface can be estimated only near 550 where it is about 23 meters (75 feet). Both interfaces are discontinuous and broken.

Outcrops along the Little Clatskanie line are clay or broken basalt, with a basalt quarry across the Apiary Road at the west end. The velocity of layer 1 decreases to the east suggesting a topsoil or more weathered, less compacted clay at the east end. Layer 2 , with velocities around $1740 \mathrm{~m} / \mathrm{s}(5700 \mathrm{f} / \mathrm{s})$, may be claystone or clayey sandstone, particularly at the east end (see magnetics model). Layer 3 
is relatively unweathered basalt with velocities of 3050 $6100 \mathrm{~m} / \mathrm{s}(10,000-20,000 \mathrm{f} / \mathrm{s})$. The slower stratum may be a vesicular area at the top of the basalt flow, or a broken or fractured layer of the basalt, or sediments. The many discontinuities have been modelled as faults, with vertical movement. The downdropped blocks near 2750 and in section 550 - 1100 may be channels cut in the basalt but some sediments, which do not show up, would be expected in them. There are no extensive non-broken areas, but most of the discontinuities are concentrated near 550 and from 1650 to 2750 .

The faulted area near 550 is near the Clatskanie River, and the down to the east movement agrees with what can be seen at the Apiary Road, where there is a basalt outcrop and quarry on the west side and a canyon with the clatskanie River on the east side of the road. The sense of movement on faults along the line varies.

\section{Comparison}

The Shaffer Road and Little Clatskanie lines have similar velocities and style of time-distance plots, and are different from the Bunker Hill line. The Shaffer Road and Little Clatskanie lines have four layers of 1370 - $1675 \mathrm{~m} / \mathrm{s}$ $(4500-5500 \mathrm{f} / \mathrm{s}), 2135-2440 \mathrm{~m} / \mathrm{s}(7000-8000 \mathrm{f} / \mathrm{s}), 3050+$ $\mathrm{m} / \mathrm{s}(10,000+\mathrm{f} / \mathrm{s})$ and a slow layer occasionally below the fastest one. They have discontinuities along the line, and the seismic records for both are generally poor, even for the 
shortest refraction line segments. The material along both lines absorbed energy quickly. The Bunker Hill line is the only line with a slow "weathering" layer of $520-1000 \mathrm{~m} / \mathrm{s}$ $(1700-3300 \mathrm{f} / \mathrm{s})$. Other layers of $1675 \mathrm{~m} / \mathrm{s}(5500 \mathrm{f} / \mathrm{s})$, $2135-2440 \mathrm{~m} / \mathrm{s}(7000-8000 \mathrm{f} / \mathrm{s})$ and $3050+\mathrm{m} / \mathrm{s}(10,000+\mathrm{f} / \mathrm{s})$ are also present, but there is no slow layer below layer 3 . This line is less broken, with faulted areas occurring at three distinct places along the line and relatively undisturbed areas in between.

\section{MAGNETICS}

General

Interpretation of this magnetic survey can be only qualitative since the magnetic susceptibility $(k)$, the magnetite content of the rock, local earth field vectors, and the remnant magnetization are not known. Magnetic anomalies are caused by local variations in magnetization of the rocks. These local changes are primarily determined by variations in the susceptibility, $k$, which in turn depends on the amount of magnetite present in the rock. Since the remnant magnetization is usually variable and too small to measure, it is assumed, in interpretation, that the entire anomaly is due to induced magnetization. The nuclear precession magnetometer used in this survey measures the total magnetic field along the earth's field vector. This is because where F (the earth's field) is much larger than $T$ (the local disturbance) the resultant, from vector 
addition, is not noticeably different from $F$. The earth's magnetic field near Portland is approximately 55,000 gammas (.55 gauss) and the inclination is $70^{\circ}$. For interpretation, an inclination of $70^{\circ}$ for the total field vector is approximately the same as the vertical field (Van Blaricom, 1980). The amplitude and shape of a magnetic anomaly is a function of depth and contrast in magnetic susceptibility between two rock types. Generally, the broader the anomaly, the deeper the source. Depths determined by any method are maximum depths and the source may be closer to the surface. Depths for the interpretation of the anomalies in the three lines were determined by the $\frac{1}{2}$ width rules (Van Blaricom, 1980, p.234) for symmetrical anomalies, and Peters' slope method (Dobrin, 1976, p.544) for asymmetrical anomalies. The $\frac{1}{2}$ width rules are usually accurate within $20 \%$, and both methods are within $10 \%$ to $50 \%$ of the real depth. Anomalies of several hundred gammas are due to magnetization contrasts, not irregularities in uniformly magnetized rock. The magnetic susceptibility for basalt is $10^{-3}$ to $10^{-4} \mathrm{cgs}$ units, and for sediments it is about $10^{-5}$ to $10^{-6}$.

Interpretation of magnetic anomalies assumes 1) the source can be modelled by a simple shape such as a sphere, cylinder or sheet, 2) magnetization within the model shape is uniform, and 3) magnetization within the shape is different from magnetization outside it. Error can occur from 1) the survey method, 2) local electrical noise or magnetic 
objects such as cars and fences, 3) magnetic storms, and 4) misinterpretation of anomalies. Magnetic data is listed in Appendix C.

Bunker Hill Line

The Bunker Hill magnetics line has a background level of 55,200 to 55,300 gammas (Figure 26). The area from $2200 \mathrm{~W}$ to $550 \mathrm{w}$ contains a broad anomaly with several smaller ones superimposed upon it (Figures 26 and 27). A shallow sharp anomaly occurs at 225E. An increase in $k$, magnetic susceptibility, is seen near $1000 \mathrm{E}$ and continues to 1650E. Two anomalies occur between $1650 \mathrm{E}$ and 1750E. The anomalies do not follow the topography, therefore they represent subsurface contrasts in magnetization.

All of the anomalies can be modelled as vertical cylinders, or thick or thin slabs. There is no direct evidence of tilting or dipping. The area between $2200 \mathrm{~W}$ and 550W is modelled by large blocks raised and lowered (faulted?) in relation to one another, with maximum depths of $21-76$ meters $(70-250$ feet $)$. The anomaly at $225 \mathrm{E}$ is interpreted to be a vertical slab less than 25 meters ( 80 feet) deep. The increase in magnetic susceptibility between $1000 \mathrm{E}$ and $1650 \mathrm{E}$ is probably due to a broad slab or faulted block. The anomaly in section 1800E - $2400 \mathrm{E}$ may be two faulted blocks at maximum depths of $43-49$ meters (140 - 160 feet). A horizontal slab at about 18 meters (60 feet) depth is a possible interpretation for the asymmetric anomaly in 
section 2500E - 2750E. The magnetization contrasts could be due to blocks of basalt with different amounts of weathering being faulted up or down in relation to each other, although contrasts with large lateral extent may be parts of different flows, or lateral variations in a single flow.

\section{Shaffer Road Line}

The Shaffer Road magnetics line is more complex than the Bunker Hill line, following the same relationship as the refraction lines. Sharp anomalies are present near 1300 and 3400 with a broad area containing several anomalies from 2000 to 3000 (Figures 28 and 29). The general background level of magnetization agrees with the regional average of 55,000 gammas.

The anomaly at 1300 can be interpreted as a gently dipping slab (or broken, tilted, thin layer) a little more than 30 meters (100 feet) beneath the surface. Wide thick blocks, less than 18 meters (60 feet) deep, can be modelled for the similar anomalies in sections 1400 - 1800 and 2700 3000. The blocks dip slightly in opposite directions, away from the large broken area in section 2000 - 2600. This broad anomaly can be separated into smaller blocks and a horizontal slab (or thin plate) from 9 to 36 meters (30 to 120 feet) deep. An area of negative anomaly occurs from 3000 - 3850, about 200 gammas below the regional average, which is modelled by a shallow vertical slab at 3450 . This decrease in magnetization may be due to a lateral change in 


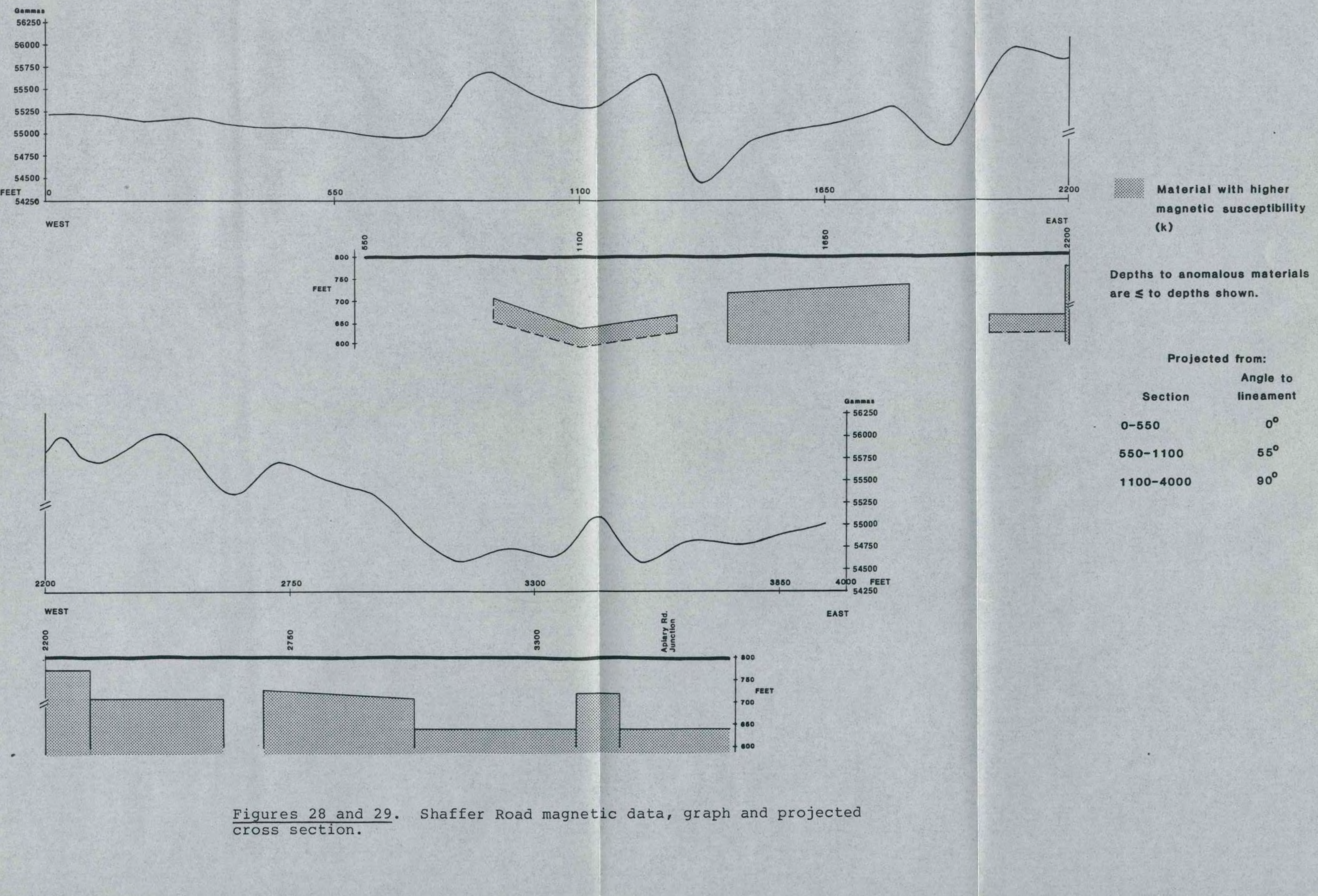


the basalt or a sedimentary layer.

\section{Little Clatskanie River Road Line}

The Iittle clatskanie River Road magnetics line shows a background level which agrees with the regional value (Figure 30). A relatively large anomaly occurs at the west end of the line, with a wide area of anomalies from 1000 2400. East of 2400 no large anomalies are evident (Figures 30 and 31 ).

This line can be modelled as a series of faulted blocks with a deep horizontal slab at the western end. A large mass of basalt occurs across the road from the west end and this may have an influence on the large anomaly near that end of the line. The section from 600 - 2000 appears to be a series of faulted blocks at depths of 18 - 76 meters (60 - 250 feet). Near 2400 a change in magnetization occurs with the remaining area to the east showing no significant anomalies, possible representing sediments near the surface, or a thick, deeply weathered layer in this area.

\section{Comparison}

The Bunker Hill line has a different magnetic character than the Shaffer Road and Little Clatskanie River lines, however even these two lines differ more from each other than they did in refraction. All three lines contain one large, broad anomaly with smaller anomalies superimposed on it. The Bunker Hill line has a background level higher than 


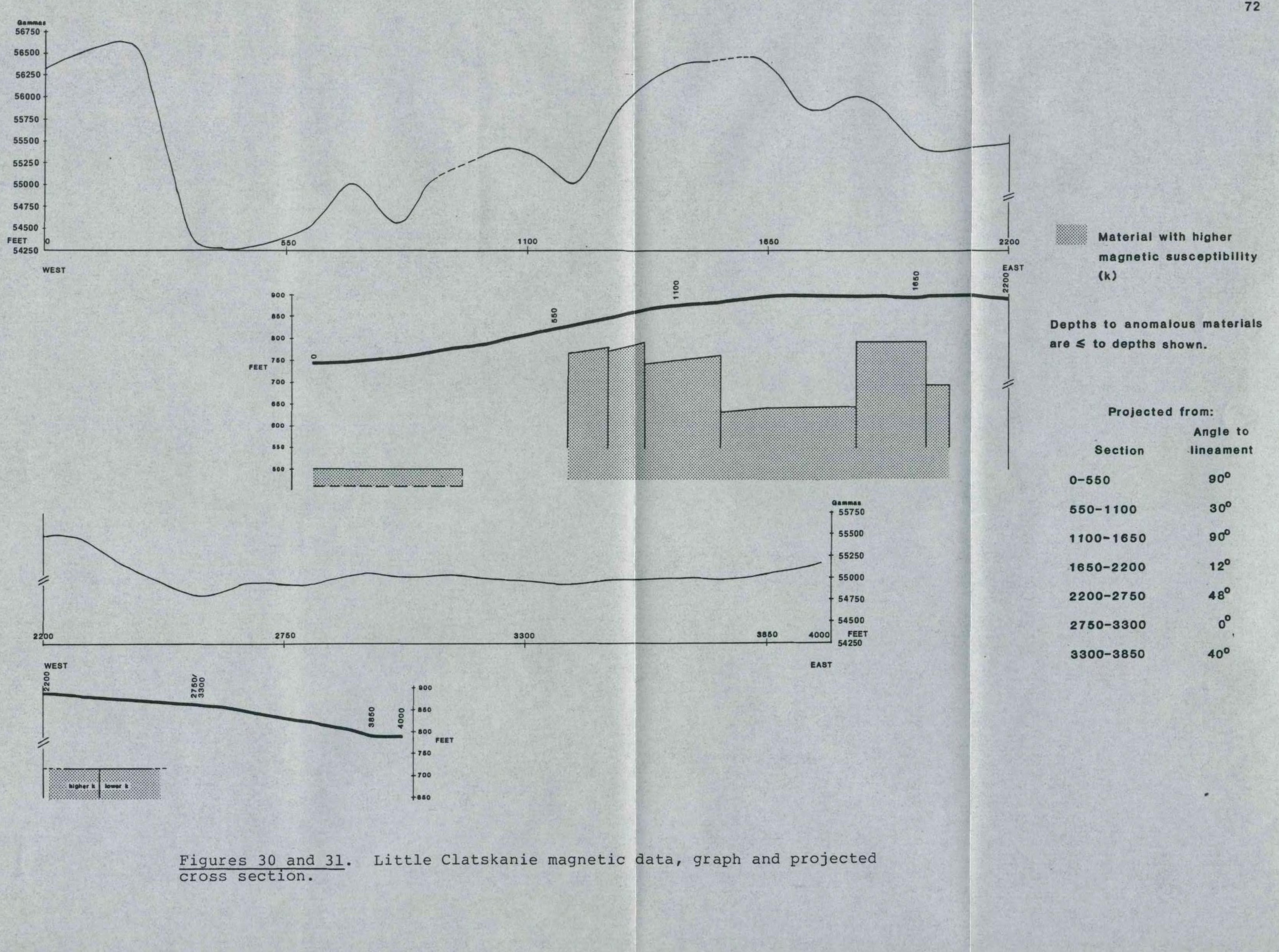


the regional average while the two northern lines are close to the regional value of 55,000 gammas. On the Bunker Hill and Little Clatskanie lines a horizontal slab or thin plate is located near suspected faults, while the Shaffer Road line has these features near areas which are not seen as faults in the modelling. Depths to basalt (high k) are similar on all three lines. 


\section{DISCUSSION AND CONCLUSIONS}

\section{DISCUSSION}

The Spitzenberg gravity line is the southernmost geophysical line in this study (Figure 2 ). The gravity readings for this line show a low at Alder Creek which continues east for about two kilometers. This low was modelled (Figure 17) with a zone of low density material, possibly unconsolidated sand, gravel or broken rock. A sedimentary high extends one kilometer east of this zone, then basalt is found over sediments to the east end of the line. The basalt block models with a relatively smooth lower surface indicating it was probably deposited on a sedimentary surface with few irregularities. A fault has been mapped along North Scappoose Creek and Alder Creek and lines up with the western edge of the low density zone (Wilkinson and others, 1946; Marty, 1983, in preparation). A fault has been mapped east of Alder Creek, occurring in the low density and sedimentary material (Marty, 1983, in preparation). The basalt seen at the surface does not show up in the gravity model, and therefore is probably less than 30 meters (100 feet) thick in the three kilometers east of Alder Creek. Any thicker layer of basalt would require modelling thicker, less dense, material below it to match the measured gravity. 
The Bunker Hill refraction/magnetics line is about five kilometers northwest of the spitzenberg line along a ridge which separates the Alder Creek and Clatskanie River drainages (Figures 2 and 10). A ponded marshy area, which could be sag ponds, follows the lineament northwest from Bunker Hill for about 1.5 kilometers. The Bunker Hill refraction data shows a fault with approximately 33 meters of offset, up on the east. This offset coincides with a saddle where the lineament crosses Bunker Hill. There is a possible fault with about the same offset approximately 500 meters west, and a zone of broken blocks approximately 500 meters east of the Alder Creek - Clatskanie River lineament. The magnetics data does not show a sharp boundary for the fault in the saddle but does indicate the general westward decrease in depth to the top of the basalt. The blockiness of the model could be smoothed. The anomalous area from $400 \mathrm{~W}$ to $2200 \mathrm{~W}$ could be modelled as a larger structure, and not only as individual blocks (Figures 26 and 27). The sharp anomaly at $225 \mathrm{E}$ is different from others on the line and is probably an artifact due to a cultural feature, such as a drain pipe crossing under the road.

The Shaffer Road refraction/magnetics line, Apiary gravity line and Little Clatskanie River refraction/magnetics line are 12 kilometers northwest of the Bunker Hill line (Figure 2). These geophysical lines cross three lineaments, the Clatskanie River, its offset, and the Little Clatskanie 
River. The Apiary gravity line models with a layer of basalt across the lineaments, between two sedimentary highs (Figure 16). It is not obvious from the gravity model whether these were highs when the basalt was deposited, whether they were the result of folding after basalt deposition, or resulted from continuous uplift during deposition. The irregular nature of the lower surface of the basalt blocks suggests they were deposited on an irregular erosional surface. The non-uniform thickness of the basalt may be due to non-uniform deposition, uplift and erosion after deposition, non-uniform coverage by different basalt flows, or a combination of these. The basalt block is thickest between Shaffer Road and the Little Clatskanie River, thinning to the east and west. The Clatskanie River, which has been following the lineament northwest, is offset approximately 1.5 kilometers to the northeast along the Apiary line, then turns northwest and parallels the lineament trend (Figure 23). The Little Clatskanie River parallels the offset Clatskanie River about one kilometer east. The original Alder Creek - Clatskanie River lineament continues northwest across the Apiary line for several kilometers, including an area of ponds, possibly sag ponds. The refraction/magnetics line is offset across the three lineaments, with the Shaffer Road line along the Clatskanie River offset section, and the Little Clatskanie River line approximately 2.5 kilometers north, between the clatskanie and 
Little Clatskanie Rivers (Figure 12). Refraction (Figures 22 and 25) indicates that relatively unweathered basalt is at or very near the surface along most of the line, with a dropped down section near the east end. The magnetic data (Figures 29 and 31) generally follows the increasing depth to basalt to the east, after smoothing out the anomalous area from 2000 to 3000 . The anomaly at 3300 may relate to the fault at the same location shown on the refraction model. The Little clatskanie line is quite faulted and this is indicated by both refraction and magnetics. Here again the magnetics model, after smoothing, generally follows the basalt surface as shown by the refraction model.

The three geophysical methods used, gravity, magnetics, and seismic refraction produce complimentary but not necessarily identical results. The spacing between gravity stations equals an entire refraction section, or several magnetics stations. Thus the scale of modelling is different for each method. In this study refraction models from ground level down to the top of the basalt, typically less than 100 meters deep. Magnetics, with 30.5 meter (100 foot) spacing between stations, models to a similar depth, however the magnetic data can be smoothed (eliminating one or two point anomalies) to give a deeper model. Gravity, on the scale modelled here, requires a layer of anomalous material to be approximately 30 meters thick to be seen on the model. Density contrasts within a few kilometers of the surface are 
modelled here. Therefore, progressively deeper features are seen from refraction to magnetics to gravity. The specific features on each type of model may not correlate well due to the scale differences, and they may be from different sources.

Gravity and magnetics are potential fields and the interpretation of an anomaly does not have a unique solution. A shallow wide body may produce a disturbance in the potential field similar to a deeper narrower body. This emphasizes again the need for integration and comparison of data from all geophysical methods with available geologic data, which allows a reasonable range of possible solutions to be proposed.

\section{CONCLUSIONS}

Available evidence tends to confirm the hypothesis that the North Scappoose Creek - Alder Creek - Clatskanie River lineament indicates a northwest-trending fault zone. The lineament is quite distinctive on SLAR, air photos and topographic maps and appears to represent the western margin of the proposed fault zone. The zone extends east from the lineament approximately two kilometers. The zone is better defined to the south, on the spitzenberg gravity and Bunker Hill refraction lines, and is less well defined on the northern lines. The lineament becomes less obvious north of the Apiary Road but two lineaments, offset 1.5 and 2 kilometers to the east, continue the northwest trend. Sag ponds, 
a feature sometimes associated with recent fault activity, occur along the lineament in at least two locations. The three geophysical methods used differentiate basalt and sediments by indicating contrasts in various physical properties. Both gravity models show anomalies associated with the proposed fault zone, a block of very low density material on the Spitzenberg model, and a thicker section of basalt on the Apiary model between Shaffer Road (kilometer 83) and the Little clatskanie River (kilometer 85). The low density material in the spitzenberg model may be broken and fractured rock, or clay. On both models the proposed fault zone is bounded on the east by a sedimentary high. The refraction and magnetic models show that the surface, or near surface, basalt is broken and faulted. This may be due to fault zone activity, or it may be the reaction of a thin, brittle skin to regional compression. This may be one reason why there is no major offset indicated in the near surface data. The deeper evidence for faulting is not clear cut in the gravity models, however $2.4 \mathrm{~g} / \mathrm{cm}^{3}$ sediments faulted against $2.5 \mathrm{~g} / \mathrm{cm}^{3}$ sediments may not show up, particularly since the $2.5 \mathrm{~g} / \mathrm{cm}^{3}$ for the Cowlitz Formation is an average for sediments $\left(\sim 2.4 \mathrm{~g} / \mathrm{cm}^{3}\right)$ and interbedded volcanics.

Probable recent activity along the proposed fault zone is indicated by the sag ponds, the linear nature and youthful appearance of the lineaments, and the occurrence at the 
surface of unweathered basalt against well weathered basalt and clay. The thick (600 - 700 meter) low density material in the Spitzenberg gravity model may indicate continuing activity during the mid to late Tertiary, or earlier. This block, which is modelled as being above the upper Eocene sediments, could also be modelled as two or three narrower, thicker, blocks which might indicate continuous activity over a longer period of time (Wang and others, 1978). There is not enough evidence to determine the sense of movement along the porposed fault zone. Right lateral strike slip motion would fit with the regional north - south compressive stress.

The complete Bouguer gravity values, when plotted on the state gravity anomaly map, fit the -20 and -30 milligal contours. The -25 and -35 milligal contours also follow the local trend on the state map, however the -40 milligal contour does not agree with the state Bouguer anomaly map (Figure 32 ). The -40 milligal contour continues northwest farther into Columbia County then loops back and rejoins the state map's -40 milligal contour. This loop enphasizes the northwesterly trend of the Portland Hills fault and the North Scappoose Creek - Alder Creek - Clatskanie River Iineament. This change in the state map fits with the more northwesterly trend in the -20 and -30 milligal contours found in the Portland area by Perttu (1980). 


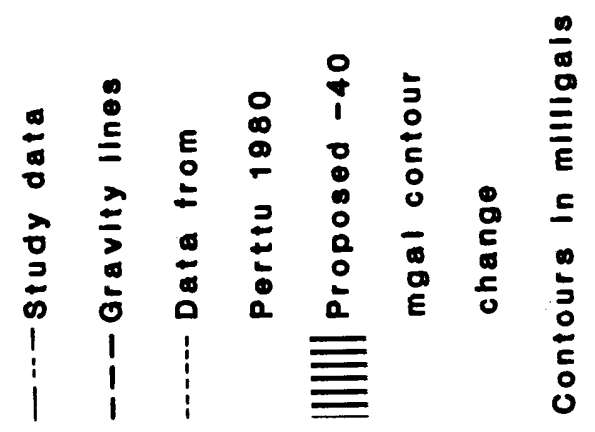

굼

도

年

$3 \pi$

c이

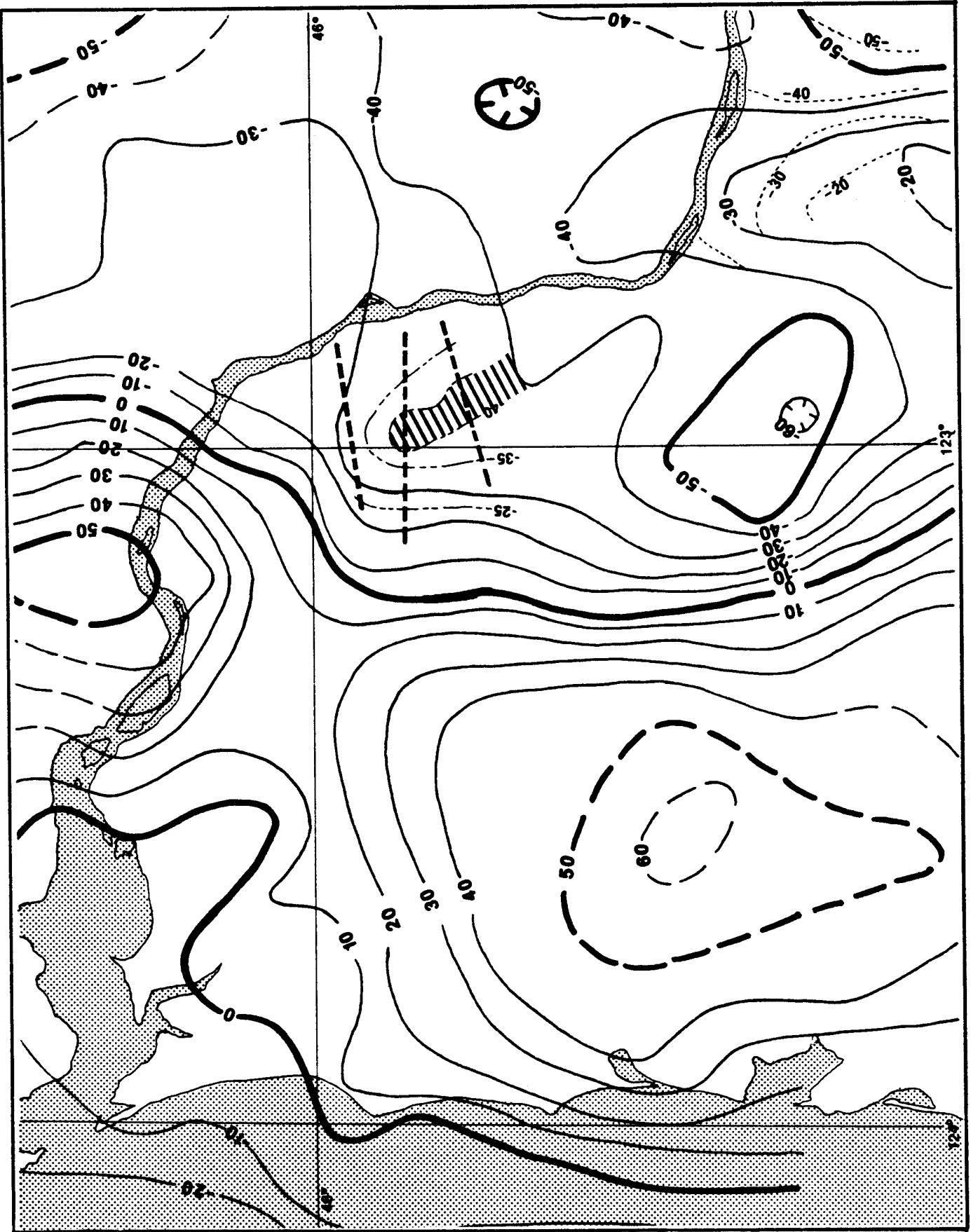

0

or $v$

(1) H

幽足

c $\stackrel{+}{0}$

it

0

U

3

$3 \cdot-1$

담담

도 도

¿

40

ते

م.

EN

>⿵冂⿰丿㇄⺀⿺

$+\pi$

$\stackrel{-1}{>}$

\%

비늘

$4+$

(1)

ต 3

거

盾

$\stackrel{0}{+1}$

(1)

है

0 넌

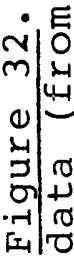




\section{REFERENCES}

Anderson, J.L., 1978, The stratigraphy and structure of the Columbia River Basalt in the Clackamas River drainage: unpublished thesis, M.S., Portland State University, Portland, Oregon.

Atwater, T.M., 1970, Implication of plate tectonics for the Cenozoic tectonic evolution of western North America: Geological Society of America Bulletin, V. 81, p. 3513 - 3536 .

Balsillie, J.H., and Benson, G.T., 1971, Evidence for the Portland Hills fault: The Ore Bin, v. 33, no. 6 , p. $109-118$.

Barthelmes, A.J., 1946, Application of continuous profiling to refraction shooting: Geophysics, V. 1l, no. 1 , p. $24-42$.

Beaulieu, J.D., and Peterson, N.V., 1981, Seismic and volcanic hazard evaluation of the Mount St. Helens area, Washington, relative to the Trojan nuclear site, Oregon: Oregon Department of Geology and Mineral Industries, Open File Report 0-81-9.

Beck, M.E., Jr., 1980, Paleomagnetic record of plate margin tectonic processes along the western edge of North America: Journal of Geophysical Research, v. 85, no. B12, p. 7115 - 7131 .

Beck, M.E., Jr., and Burr, C.D., 1979, Paleomagnetism and tectonic significance of the Goble Volcanic Series, southwest washington: Geology, v. 7, p. 175 - 179.

Beck, M.E., Jr., and Plumley, P., 1980, Paleomagnetism of intrusive rocks in the coast Range of Oregon: Microplate rotations in middle Tertiary time: Geology, v. 8 , p. $573-577$.

Beeson, M.H., Johnson, A.G., Moran, M.R., 1976, Portland environmental geology - fault identification; Final technical report to United States Geological Survey: Earth Sciences Dept., Portland State University, Portland, Oregon. 
Beeson, M.H., Johnson, A.G., Moran, M.R., 1977, Fault identification and structural evolution of the

Portland area: Proc. Oregon Academy of Science, p. 58 (abstract).

Benson, G.T., and Donovan, J.C., 1974, Preliminary tectonic map of the greater Portland area: in Hammond, P.E., and others, 1974, A preliminary geological investigation of the ground effects of earthquakes in the Portland metropolitan area, Oregon: unpublished report to the United States Geological Survey (PEG I report), Portland State University, Portland, Oregon.

Berg, J.W., Jr., and Baker, C.D., 1962, Oregon earthquakes, 1841 through 1958: The Ore Bin, v. 24, no. 9, p. 143 149 .

, 1963, Oregon earthquakes, 1841 through 1958:

Seismological Society of America Bulletin, v. 53, p. $95-108$.

Berg, J.W., Jr., and others, 1966, Crustal refraction profile, Oregon Coast Range: Seismological Society of America Bulletin, v. 56, p. 1357 - 1362 .

Berg, J.W., and Thiruvathukal, J.V., 1967a, Free air gravity anomaly map of Oregon: Oregon Department of Geology and Mineral Industries, GMS 4a, scale 1:500,000.

- 1967b, Complete Bouguer gravity anomaly map of Oregon: Oregon Department of Geology and Mineral Industries, GMS $4 \mathrm{~b}$, scale $1: 500,000$.

Bonini, W.E., Hughes, D.W., and Danes, Z.F., 1974, Complete Bouguer gravity anomaly map of Washington: Division of Geology and Earth Resources, State of Washington, Department of Natural Resources, geologic map GM-11, scale $1: 500,000$.

Bromery, R.W., and Snavely, P.D., Jr., 1964, Geologic interpretation of reconnaissance gravity and aeromagnetic surveys in northwestern Oregon: United States Geological Survey Bulletin 1181-N.

Bruer, W.G., 1980, Mist gas field, Columbia County, Oregon: American Association of Petroleum Geologists Bulletin, v. 64 , no. 3, p. 439 (abstract).

Cash, D.J., 1973, A gravity survey in northeast Portland: unpublished paper, Portland State University, Portland, Oregon. 
Couch, R., Johnson, S., and Gallagher, J., 1968, The Portland earthquake of May 13, 1968, and earthquake energy release in the Portland area: The Ore Bin, v. 30 , no. 10 , p. $185-190$.

Couch, R., and Lowell, R.P., 1971, Earthquakes and seismic energy release in Oregon: The Ore Bin, v. 33, no. 4, p. $61-84$.

Couch, R.W., and Mac Farlane, W.T., 1971, A fault plane solution of the October 1969, Mt. Rainier earthquake and tectonic movements in the Pacific Northwest: Derived from fault plane and first motion studies: EOS, v. 52, p. 428 (abstract).

Crosson, R.S., 1972, Small earthquakes, structure and tectonics of the puget Sound region: Seismological Society of America Bulletin, v. 62, no. 5, p. 1133 1171 .

Dehlinger, P., 1969, Tectonic processes in the Juan de Fuca and Gorda ridges, and their implications for global tectonics: EOS, v. 50, p. 186 (abstract).

Dehlinger, P., and Berg, J.W., Jr., 1962, The Portland earthquake of November 5, 1962: The Ore Bin, v. 24, no. 11, p. $185-188$.

Dehlinger, P., Bowen, R.G., Chilburis, E.F., and Westphal, W.H., 1963, Investigations of the earthquake of November 5, 1962, north of Portland: The Ore Bin, v. 25 , no. 4 , p. $53-68$.

Dehlinger, P., and Couch, R.W., 1969, Synthesis of geophysical results in the Juan de Fuca and Gorda Ridge areas (Northeast Pacific Ocean): EOS, v. 50, p. 186 (abstract).

Dehlinger, P., Rinehart, R.W., Couch, R.W., and Gemperle, M., 1967, Free air gravity anomaly map west of Oregon: Oregon Department of Geology and Mineral Industries, GMS 4c, scale 1:500,000.

Dickinson, W.R., 1976, Sedimentary basins developed during evolution of the Mesozoic - Cenozoic arc-trench system in western North America: Canadian Journal of Earth Sciences, v. 13, p. 1268 - 1287. 
Dickinson, W.R., 1979, Cenozoic plate tectonic setting of the cordilleran region in the U.S.: in Cenozoic paleogeography of the western U.S., J.M. Armentrout, ed., Pacific Coast Paleogeography Symposium No. 3, SEPM, Los Angeles, California.

Diller, J.S., 1896, A geological reconnaissance in the northwest Oregon: United States Geological Survey, 17 th Annual Report, part 3, p. 441 - 520.

Dobrin, M.B., 1960, Introduction to geophysical prospecting: New York, McGraw Hill Book Company; 1976, 3rd edition.

Dix, C.H., 1939, Refraction and reflection of seismic waves, I. Fundamentals: Geophysics, v. 4, no. 2, p. 81 - 101 .

, 1939, Refraction and reflection of seismic waves, II. Discussion of the physics of refraction prospecting: Geophysics, v. 4, no. 4, p. 238 - 241 .

, 1941, Notes on refraction prospecting: Geophysics, v. 6 , no. 4 , p. $378-396$.

, 1952, Seismic prospecting for oil: New York, Harper and Row.

DOGAMI, 1978, Geologic hazards review, Trojan nuclear power plant site, Columbia County, Oregon: Open file report $78-1$.

Donath, F.A., and Kuo, J.T., 1962, Seismic refraction study of block faulting, south-central Oregon: Geological Society of America Bulletin, v. 73, no. 4, p. 429 434 .

Ewing, M., Wollard, G.P., and Vine, A., 1939, Geophysical investigations in the emerged and submerged Atlantic coastal plain, Part III: Geological Society of America Bulletin, v. 50, p. $257-296$.

Hamilton, W., 1978, Mesozoic tectonics of the Western U.S.: in Mesozoic paleogeography of the western U.S., D.G. Howell, ed., Pacific Coast Paleogeography Symposium, No. 2, SEPM, Los Angeles, California.

Hammer, S., 1939, Terrain corrections for gravimeter stations: Geophysics, v. 4, no. 3, p. 184 - 194. 
Hammond, P.E., 1979, A tectonic model for evolution of the Cascade Range: in Cenozoic paleogeography of the western U.S., J.M. Armentrout, ed., Pacific Coast Paleogeography Symposium No. 3, SEPM, Los Angeles, CA.

, 1980, Reconnaissance geologic map and cross sections of southern Washington Cascade Range: Department of Earth Sciences, Portland State University, scale $1: 125,000,2$ sheets, booklet.

Hammond, P.E., Benson, G.T., Cash, D.J., Palmer, L.A., Donovan, J., and Gannon, B., 1974, A preliminary geologic investigation of the ground effects of earthquakes in the Portland Metropolitan area, Oregon: unpublished report to the United States Geological Survey.

Hales, F.W., 1958, An accurate graphical method for interpreting seismic refraction lines: Geophysical Prospecting, v. 6, p. $285-304$.

Hawkins, L.V., 1961, The reciprocal method of routine shallow seismic refraction investigations: Geophysics, v. 26 , no. 6, p. $806-819$.

Heiland, C.A., 1968, Geophysical exploration: New York, Hafner Publishing Company.

Heinrichs, D.F., and Pietrafesa, L.J., 1968, The Portland earthquake of January 27, 1968: The Ore Bin, v. 30, no. 2 , p. $37-40$.

Jakosky, J.J., 1940, Exploration geophysics: Los Angeles, Los Angeles Times Mirror Press.

Johnson, A.G., 1976, Gravity profiles across the northeast side of the Tualatin Mountains, Portland, Oregon: Transactions, American Geophysical Union, v. 57, no. 2, p. 89 (abstract).

Johnson, A.G., and Jones, T., 1976, Gravimetric investigations of the tectonics of the Portland Hills: Transactions, American Geophysical Union, v. 57, no. 20 , p. 897 (abstract).

Johnson, A.G., Jones, T., and Perttu, J.D., 1977, Interpretation of gravity in the Portland area: Proc. of Oregon Academy of Science, p. 60 (abstract).

Jones, D.L., Cox, A., Coney, P., and Beck, M., 1982, The growth of western North America: Scientific American, v. 247 , no. 5, p. $70-84$. 
Jones, T.D., 1977, Analysis of a gravity traverse south of Portland, Oregon: unpublished thesis, B.S., Portland State University, Portland, Oregon.

Kadri, Moinoddin, 1982, Structure and influence of the Tillamook uplift on the stratigraphy of the Mist area, Oregon: unpublished thesis, M.S., Portland state University, Portland, Oregon.

Kelty, K.B., 1981, Stratigraphy, lithofacies and environment of deposition of the Scappoose Formation in central Columbia County, Oregon: unpublished thesis, M.S., Portland State University, Portland, Oregon.

Lawrence, R.D., 1976, Strike-slip faulting terminates the Basin and Range Province in Oregon: Geological Society of America Bulletin, v. 87, no. 6, p. 846 850 .

Levorsen, A.I., 1960, Paleogeologic maps: San Francisco, W.H. Freeman and Company.

Magill, J., and Cox, A., 1980, Tectonic rotation of the Oregon western Cascades: Oregon Department of Geology and Mineral Industries, special paper 10 .

- 1981, Post-Oligocene tectonic rotation of the Oregon western Cascade Range and the Klamath Mountains: Geology, v. 9, no. 3, p. 127 - 131 .

Magill, J., Cox, A., and Duncan, R., 1981, Tillamook Volcanic Series: Further evidence for tectonic rotation of the Oregon Coast Range: Journal of Geophysical Research, v. 86, no. B4, p. 2953 - 2970.

Magill, J.R., Wells, R.E., Simpson, R.W., and Cox, A.V., 1982 , Post $12 \mathrm{~m} . \mathrm{Y}$. rotation of southwest Washington: Journal of Geophysical Research, v. 87, no. B5, p. 3761 - 3776 .

Marty, R., 1983, Formation and zonation of ferruginous bauxite deposits, Columbia County, Oregon: thesis in preparation, M.S., Portland State University, Portland, Oregon.

Mota, Lindonor, 1954, Determination of dips and depths of geological layers by the seismic refraction method: Geophysics, v. 19, no. 2, p. 242 - 254 .

Musgrave, A.W., 1967, Seismic refraction prospecting: Tulsa, Society of Exploration Geophysicists. 
Nettleton, L.L., 1940, Geophysical prospecting for oil: New York, Mc Graw-Hill Book Company.

, 1971, Elementary gravity and magnetism for geologists and seismologists: Tulsa, SEG Monograph, Series 1 .

Newton, V.C., Jr., 1969, Subsurface geology of the Lower Columbia and Willamette Basins, Oregon: Oregon Department of Geology and Mineral Industries, Oil and Gas Investigation, No. 2 .

- 1979, Subsurface correlations in the Mist area, Columbia County, Oregon: Oregon Geology, v. 41, no. 12 , p. 193 - 196 .

Newton, V.C., and Van Atta, R.O., 1976, Prospects for natural gas production and underground storage of pipeline gas in the upper Nehalem River basin, Columbia and Clatsop Counties, Oregon: Oregon Department of Geology and Mineral Industries, $0 i 1$ and Gas Investigation, No. 5 .

Northwood, E.J., 1967, Notes on errors in refraction interpretation: in Musgrave, A.W., ed., 1967, Seismic refraction prospecting: Tulsa, SEG.

Perttu, J.D., 1980, An analysis of gravity surveys in the Portland Basin, Oregon: unpublished thesis, M.S., Portland State University, Portland, Oregon.

Pfaff, V.J., 1981, Geophysical and geochemical analyses of selected Miocene coastal basalt features, Clatsop County, Oregon: unpublished thesis, M.S., Portland State University, Portland, Oregon.

Redpath, B.B., 1973, Seismic refraction exploration for engineering site investigations: U.S. Army Engineer Waterways Experiment Station, Livermore, California, Technical report E-73-4.

Riddihough, R.P., 1978, The Juan de Fuca Plate: EOS, V. 59, no. 9, p. $836-842$.

Rockwell, D.W., 1967, General wavefront method: in Musgrave, A.W., ed., 1967, Seismic refraction prospecting: Tulsa, SEG.

Sabins, F.F., Jr., 1978, Remote sensing: principles and interpretation: San Francisco, W.H. Freeman and Company. 
Schlicker, H.G., Deacon, R.J., and Twelker, N.H., 1964, Earthquake geology of the Portland area, Oregon: The Ore Bin, v. 26, no. 12 , p. $209-230$.

Schmela, R.J., 1971, Geophysical and geological analysis of a fault-like lineation in the Lower Clackamas River area, Clackamas County, Oregon: unpublished thesis, M.S., Portland State University, Portland, Oregon.

Simpson, R.W., and Cox, A.V., 1977, Paleomagnetic evidence for tectonic rotation of the Oregon coast Range: Geology, v. 5, p. 585 - 589 .

Skeels, D.C., 1963, An approximate solution of the problem of maximum depth in gravity interpretation: Geophysics, v. 28, p. $724-735$.

Slotnick, M.M., 1950, A graphical method for the interpretation of refraction profile data: Geophysics, v. 15, no. 2 , p. $163-180$.

Smith, R.B., and Eaton, G.P., eds., 1980, Cenozoic tectonics and regional geophysics of the western Cordillera: Geological Society of America Memoir 152.

Snavely, P.D., Jr., and Wagner, H.C., 1963, Tertiary geologic history of western Oregon and Washington: Washington Division of Mines and Geology, R.I. 22 .

, 1964, Geologic sketch of northwest Oregon: United States Geological Survey Bulletin, no. 1181-M.

- 1982, Geologic cross-section across the continental margin of southwestern Washington: United States Geological Survey, open-file report 82-459.

Snavely, P.D., Jr., Wagner, H.C., and Lander, D.L., 1980, Interpretation of the Cenozoic geologic history, central Oregon continental margin: cross-section summary: Geological Society of America Bulletin, Part I, v. 91, p. 143 - 146.

Talwani, M., Worzel, J.C., and Landisman, M., 1959, Rapid gravity computations for two-dimensional bodies with application to the Mendocino submarine fracture zone: Journal of Geophysical Research, v. 64 , no. 1, p. 49 59 .

Tatel, H.E., and Ture, M.A., 1955, Seismic exploration of a continental crust: Geological Society of America Special Paper 62, p. 35 - 50 . 
Tchalenko, J.S., 1970, Similarities between shear zones of different magnitudes: Geological Society of America Bulletin, v. 81, p. $1625-1640$.

Telford, W.M., Geldart, L.P., Sheriff, R.S., and Keys, D.A., 1976, Applied geophysics: Cambridge, Cambridge University Press.

Thiruvathukal, J.V., Berg, J.W., Jr., and Heinrichs, D.F., 1970, Regional gravity of Oregon: Geological Society of America Bulletin, v. 81, no. 3, p. 725 - 738 .

Timmons, D.M., 1981, Stratigraphy, lithofacies and depositional environment of the Cowlitz Formation $\mathrm{T} 4$ and $5 \mathrm{~N}$, R5W, northwest Oregon: unpublished thesis, M.S., Portland State University, Portland, Oregon.

Trimble, D.E., 1963, Geology of Portland, Oregon and adjacent areas: United States Geological Survey Bulletin, 1119, map scale 1:62,500.

Van Blaricom, R., Ed., 1980, Practical geophysics for the exploration geologist: Spokane, Northwest Mining Association.

Veen, C.A., 1979, A geophysical definition of a Klamath Falls Graben fault: unpublished thesis, M.S., Portland State University, Portland, Oregon.

Venkatakrishnan, R., Bond, J.G., and Kauffman, J.D., 1980, Geological linears of the northern part of the Cascade Range, Oregon: Oregon Department of Geology and Mineral Industries, special paper 12 .

Wang, C., Lin, W, and Wu, F.T., 1978, Constitution of the San Andreas Fault zone at depth: Geophysical Research Letters, v. 5, no. 9, p. $741-744$.

Warren, W.C., and Norbisrath, H., 1946, Stratigraphy of the Upper Nehalem Basin, northwest Oregon: American Association of Petroleum Geologists Bulletin, v. 30, no. 2 , p. $213-237$.

Warren, W.C., Norbisrath, H., and Grivetti, R.M., 1945, Geology of northwest Oregon: United States Geological Survey, Oil and Gas Investigations Preliminary Map 42, scale 1:250,000. 
Warrick, R.E., Hoover, D.B., Jackson, W.H., Pakiser, L.C., and Roller, J.C., 1961, The specification and testing of a seismic-refraction system for crustal studies: Geophysics, v. 26, p. $820-824$.

White, W.R.H., and Savage, J.C., 1965, A seismic refraction and gravity study of the earth's crust in British Columbia: Seismological Society of America Bulletin, v. 55 , p. $463-486$.

Wilkenson, W.D., Lowry, W.D., and Baldwin, E.M., 1946, Geology of the St. Helens Quadrangle, Oregon: Oregon Department of Geology and Mineral Industries Bulletin no. 31 .

Zietz, I., Hearn, B.C., Jr., Higgins, M.W., Robinson, G.D., and Swanson, D.A., 1971, Interpretation of an aeromagnetic strip across the northwestern United States: Geological Society of America Bulletin, v. 82, no. 12, p. 3347 - 3371 . 
APPENDIX A

SPITZENBERG GRAVITY DATA

\begin{tabular}{|c|c|c|c|c|c|c|c|}
\hline Station & Latitude & Longitude & $\begin{array}{l}\text { Elevation } \\
\text { (meters) }\end{array}$ & $\begin{array}{l}\text { Observed } \\
\text { Gravity } \\
\text { (mgals) } \\
\end{array}$ & $\begin{array}{l}\text { Terrasn } \\
\text { correction } \\
\text { (mgals) } \\
\end{array}$ & $\begin{array}{l}\text { Free Alr } \\
\text { Anomaiy } \\
\text { (mgais) } \\
\end{array}$ & $\begin{array}{l}\text { Complete } \\
\text { Bouguer } \\
\text { Aromal; } \\
\text { (mgais: }\end{array}$ \\
\hline 27 & $15^{\circ} 51.68^{\circ}$ & $122^{\circ} 51.62^{\circ}$ & 89.55 & 980653.53 & 0.08 & -25.97 & -36.04 \\
\hline 26 & $45^{\circ} 51.33^{\prime}$ & $122^{\circ}{ }^{2.75^{\circ}}$ & 109.27 & 980647.20 & 0.21 & -25.69 & -37.87 \\
\hline 25 & $45^{\circ} 51.32$. & $122^{\circ} 53.33^{\circ}$ & 95.51 & 980648.98 & 0.43 & -28.15 & $-3 B .54$ \\
\hline 24 & $45^{\circ} 51.05^{\circ}$ & $122^{\circ} 53.89^{\circ}$ & 129.94 & 980639.17 & 1.12 & -26.93 & -40.54 \\
\hline 23 & $15^{\circ} 50.77^{\circ}$ & $122^{\circ} 54^{-32^{\circ}}$ & 155.11 & 980633.63 & 0.45 & -24.28 & -41.42 \\
\hline 22 & $45^{\circ} 50.65^{\prime}$ & $122^{\circ} 54.50^{\circ}$ & 266.09 & 980631.43 & 0.64 & -22.91 & -41.10 \\
\hline 21 & $45^{\circ} 50.54^{\prime}$ & $122^{\circ} 54.74^{\circ}$ & 180.98 & 980627.54 & 0.52 & -22.05 & -42.03 \\
\hline 20 & $15^{\circ} 50.64^{\prime}$ & $122^{\circ} 54^{-94^{\circ}}$ & 190.62 & 980622.88 & 0.69 & -21.42 & -43.23 \\
\hline 19 & $45^{\circ} 50.60^{\circ}$ & $122^{\circ} 55.04^{\prime}$ & 226.67 & 980616.55 & 1.01 & -19.02 & -43.69 \\
\hline 18 & $45^{\circ} 50.52^{\prime}$ & $122^{\circ} 55.11^{\circ}$ & 240.29 & 980613.35 & 0.97 & -27.90 & -44.14 \\
\hline 17 & $45^{\circ} 50.37^{\circ}$ & $122^{\circ} 55.20^{\circ}$ & 253.56 & 980610.27 & 1.40 & -16.66 & -43.99 \\
\hline 16 & $15^{\circ} 50.27$ & $122^{\circ} 55.29^{\circ}$ & 261.73 & 980608.59 & 1.11 & -15.67 & $-44.2 i$ \\
\hline 15 & $45^{\circ} 50.23^{\prime}$ & $122^{\circ} 55.40^{\circ}$ & 262.02 & 980608.91 & 0.95 & -15.20 & -43.94 \\
\hline 14 & $45^{\circ} 50.18^{\circ}$ & $122^{\circ} 55.52^{\circ}$ & 270.91 & 980606.91 & 1.02 & -14.39 & -44.05 \\
\hline 13 & $45^{\circ} 50.15^{\prime}$ & $122^{\circ} 55.64^{\prime}$ & 280.13 & 980604.80 & 1.12 & -13.62 & -44.22 \\
\hline 12 & $45^{\circ} 50.11$ & $122^{\circ} 55.76^{\prime}$ & 289.43 & 980602.95 & 1.20 & -12.53 & -44.12 \\
\hline 11 & $45^{\circ} 50.04^{\prime}$ & $122^{\circ} 55.85$, & 302.82 & 980599.95 & 1.30 & -11.29 & -44.30 \\
\hline 10 & $45^{\circ} 49.71$ & $122^{\circ} 55.85^{\circ}$ & 276.05 & 980605.89 & 1.27 & -13.12 & -43.22 \\
\hline 9 & $45^{\circ} 49.79^{\circ}$ & $122^{\circ} 56.00^{\prime}$ & 257.99 & 980610.67 & 1.01 & -14.03 & -42.24 \\
\hline 8 & $45^{\circ} 49.84^{\prime}$ & $122^{\circ} 56.13^{\circ}$ & 240.08 & 980615.38 & 1.03 & -14.92 & -41.20 \\
\hline 7 & $15^{\circ} 49.86^{\circ}$ & $122^{\circ} 56.30^{\circ}$ & 223.87 & 980619.72 & 1.01 & -25.61 & $-39.9^{-}$ \\
\hline 6 & $45^{\circ} 49.86^{\circ}$ & $122^{\circ} 56.45^{\prime}$ & 198.87 & 900625.50 & 1.25 & -27.54 & -38.54 \\
\hline 5 & $45^{\circ} 49.85^{\circ}$ & $122^{\circ} 56.57^{\circ}$ & 181.76 & 980628.03 & 1.60 & -20.28 & -39.28 \\
\hline 4 & $15^{\circ} 49.78^{\prime}$ & $122^{\circ} 56.66^{\prime}$ & 168.50 & 980630.85 & 1.78 & -21.44 & -35.76 \\
\hline 3 & $45^{\circ} 49.52^{\circ}$ & $122^{\circ} 56.72^{\prime}$ & 162.06 & 980631.31 & 1.46 & -22.57 & $-39.4 \dot{c}$ \\
\hline 2 & $45^{\circ} 49.52^{\circ}$ & $122^{\circ} 56.82^{\circ}$ & 167.64 & 980630.60 & 1.45 & -21.56 & -39.21 \\
\hline 1 & $45^{\circ} 49.51$ & $122^{\circ} 56.94^{\prime}$ & 172.03 & 980629.60 & 1.28 & -21.20 & -39.40 \\
\hline $31^{\circ}$ & $45^{\circ} 49.50^{\prime}$ & $122^{\circ} 57.07$ & 180,00 & 980628.54 & 1.18 & -19.75 & -39.50 \\
\hline 32 & $45^{\circ} 49.48^{\prime}$ & $122^{\circ} 57.21^{\prime}$ & 187.59 & 980627.04 & 1.04 & $-18.9:$ & -39.14 \\
\hline 33 & $45^{\circ} 49.48^{\prime}$ & $122^{\circ} 57.31$ & 185.15 & 980627.76 & 1.00 & -18.94 & -38.94 \\
\hline $33 \mathrm{~A}$ & $45^{\circ} 49.56^{\prime}$ & $122^{\circ} 57.43^{\circ}$ & 182.02 & 980628.87 & 0.95 & -18.92 & -38.59 \\
\hline 34 & $45^{\circ} 49.58^{\prime}$ & $122^{\circ}{ }_{57.54^{\circ}}$ & 181.83 & 980629.18 & 0.91 & -18.69 & -38.40 \\
\hline 35 & $45^{\circ} 49.57^{\circ}$ & $122^{\circ} 57.64^{\circ}$ & 282,93 & 980629.11 & 0.94 & $-18,41$ & -38.20 \\
\hline 36 & $15^{\circ} 49.55^{\circ}$ & $122^{\circ} 57.78^{\circ}$ & 182.07 & 980629.20 & 0.98 & -18.56 & -38.29 \\
\hline 37 & $45^{\circ} 49.53^{\circ}$ & $122^{\circ} 57.92^{\circ}$ & 182.90 & 980629.14 & 0.97 & -18.33 & $-38.0 \varepsilon$ \\
\hline 38 & $45^{\circ} 49.51$ & $122^{\circ} 58.04^{\circ}$ & 184.29 & 980629.04 & 0.95 & -17.98 & $-3 \div .92$ \\
\hline 39 & $45^{\circ} 49.50^{\circ}$ & $122^{\circ} 58.17^{\circ}$ & 185.58 & 980629.02 & 0.94 & -17.58 & -37.68 \\
\hline 40 & $45^{\circ} 4.52^{\prime}$ & $122^{\circ} 58.31^{\circ}$ & 187.20 & 980628.93 & 0.93 & $-1: .20$ & -37.48 \\
\hline 41 & $45^{\circ} 49.59^{\prime}$ & $122^{\circ} 58.48^{\prime}$ & 186.85 & 980629.12 & 0.88 & -16.93 & -37.22 \\
\hline 42 & $45^{\circ} 49.63^{\prime}$ & $122^{\circ} 58.65^{\circ}$ & 187.15 & 980629.55 & 1.27 & -16.76 & $-36 .-1$ \\
\hline 43 & $45^{\circ} 49.65^{\prime}$ & $122^{\circ} 58.80^{\circ}$ & 190.54 & 980628.82 & 1.31 & $-16.4 \hat{a}$ & -36.75 \\
\hline 44 & $45^{\circ} 49.63^{\circ}$ & $122^{\circ} 58.95^{\circ}$ & 195.68 & 980627.57 & 1.31 & -16.11 & $-36.9 \varepsilon$ \\
\hline 45 & $45^{\circ} 49.64^{\circ}$ & $122^{\circ} 59.07^{\circ}$ & 193.42 & 980628.43 & 1.51 & -15.96 & $-36.3 t$ \\
\hline 46 & $45^{\circ} 49.63^{\circ}$ & $122^{\circ} 59.33^{\circ}$ & 196.84 & $980 \in 27.89$ & 1.60 & -15.44 & -36.14 \\
\hline 47 & $45^{\circ} 49.62^{\circ}$ & $122^{\circ} 59,60^{\prime}$ & 212.02 & 980624.63 & 1.74 & -13.99 & -36.28 \\
\hline 48 & 15050.07 & $123^{\circ} 00.44$ & 312.38 & 980603.28 & 1.76 & -5.06 & $-38: 00$ \\
\hline 49 & $45^{\circ} 50.30^{\circ}$ & $123^{\circ} 01.23^{\circ}$ & 347.72 & 980597.86 & 1.15 & +0.07 & -38.16 \\
\hline 50 & $45^{\circ} 50.34^{\prime}$ & $123^{\circ} 02.49^{\circ}$ & 386.88 & 980591.01 & 1.37 & +5.25 & $-3^{-} .19$ \\
\hline 51 & $45^{\circ} 49.68^{\circ}$ & $123^{\circ} 03.04^{\circ}$ & 370.63 & 980594.26 & $1.2 \%$ & +4.48 & $-3 \epsilon .23$ \\
\hline
\end{tabular}


PITTSBURG-YANKTON GRAVITY DATA

\begin{tabular}{|c|c|c|c|c|c|c|c|}
\hline Station & Laticude & Lanyztude & $\begin{array}{l}\text { Elevation } \\
\text { (meters) }\end{array}$ & $\begin{array}{l}\text { Observed } \\
\text { Gravity } \\
\text { (mquis) } \\
\end{array}$ & $\begin{array}{l}\text { Terrain } \\
\text { Correction } \\
\text { (myals) } \\
\end{array}$ & $\begin{array}{l}\text { Free Air } \\
\text { Anomaly } \\
\text { (mgals) } \\
\end{array}$ & $\begin{array}{l}\text { Complete } \\
\text { Bowyuer } \\
\text { Anomaly } \\
\text { imgals } \\
\end{array}$ \\
\hline BM 284 & $45^{\circ} 51.99^{\circ}$ & $122^{\circ} 53.17^{\circ}$ & 86.38 & 980653.30 & 0.21 & -27.65 & -37.23 \\
\hline $\operatorname{sen} 277$ & $45^{\circ} 53.61$ & $122^{\circ} \circ_{55.57^{\prime}}$ & 83.60 & 980656.61 & 1.38 & -27.64 & -35.72 \\
\hline BM4 39 & $45^{\circ} 54.15^{\prime}$ & $122^{\circ} 55.90^{\circ}$ & 133.54 & 980646.21 & 0.82 & -23.44 & -37.75 \\
\hline BM848 & $45^{\circ} 53.83^{\circ}$ & $122^{\circ} 58.14^{\prime}$ & 258.10 & 980618.90 & 0.93 & -11.84 & -40.14 \\
\hline BM 1005 & $45^{\circ} 53.4 \theta^{\circ}$ & $122^{\circ} 59.87^{\circ}$ & 305.99 & 980610,04 & 1.13 & -5.40 & -38.92 \\
\hline $\sin 1683$ & $45^{\circ} 53.63^{\circ}$ & $123^{\circ} 02.43^{\circ}$ & 512.80 & 980565.91 & 1.45 & +14.05 & -42.54 \\
\hline BM1751 & $45^{\circ} 53.50^{\circ}$ & $123^{\circ} 03.62^{\prime}$ & 533.63 & 980563.70 & 2.76 & +18.45 & -39.18 \\
\hline $\operatorname{sen} 1403$ & $45^{\circ} 53.88^{\circ}$ & $123^{\circ} 06.10^{\prime}$ & 427.33 & 980593.19 & 2.33 & +14.58 & -31.47 \\
\hline $\operatorname{Bg} 855$ & $45^{\circ} 54.45^{\prime}$ & $123^{\circ} 07.68^{\circ}$ & 260.24 & 980638.10 & 1.01 & +7.09 & -21.37 \\
\hline BM586 & $45^{\circ} 54.09^{\circ}$ & $123^{\circ} 08.64^{\circ}$ & 178.25 & 980658.64 & 0.88 & +2.87 & -16.44 \\
\hline
\end{tabular}


APIAFY GRAYITY DATA

\begin{tabular}{|c|c|c|c|c|c|c|c|}
\hline Station & Latitude & Longitude & $\begin{array}{l}\text { Elevation } \\
\text { meters) }\end{array}$ & $\begin{array}{l}\text { Obse:ved } \\
\text { Gravity } \\
\text { (mgals) } \\
\end{array}$ & $\begin{array}{l}\text { Terrain } \\
\text { Correction } \\
\text { (mgals) } \\
\end{array}$ & $\begin{array}{l}\text { Free Azr } \\
\text { Anomaly) } \\
\text { (mgals) }\end{array}$ & $\begin{array}{l}\text { Complete } \\
\text { Bougue: } \\
\text { Anoraly } \\
\text { (mgals: }\end{array}$ \\
\hline 46 & $15^{\circ} 57.66^{\prime}$ & $122^{\circ} 52.03^{\circ}$ & 16.99 & 980682.72 & 0.82 & -28.17 & -29.27 \\
\hline 45 & $45^{\circ} 58.26^{\circ}$ & $122^{\circ} 53.02^{\circ}$ & 182.23 & 980648.74 & 0.69 & -12.07 & -32.03 \\
\hline 44 & $45^{\circ} 37.60^{\circ}$ & $122^{\circ} 54.25^{\circ}$ & 185.93 & 980645.69 & 0.54 & -12.98 & -33.52 \\
\hline 43 & $15^{\circ} 58.03^{\circ}$ & $122^{\circ} 54^{\prime} .99^{\circ}$ & 161.86 & 980652.27 & 0.21 & -14.47 & -32.61 \\
\hline 42 & $45^{\circ} 58.07^{\circ}$ & $122^{\circ} 55.67^{\circ}$ & 244.31 & 980656.98 & 0.25 & -15.25 & -31.34 \\
\hline 41 & $45^{\circ} 58.03^{\circ}$ & $122^{\circ} 56.32^{\prime}$ & 170.18 & 980650.59 & 0.38 & -13.59 & -32.49 \\
\hline 10 & $45^{\circ} 58.08^{\prime}$ & $122^{\circ} 57.00^{\circ}$ & 97.11 & 980668.43 & 0.52 & -18.26 & $-28 .=0$ \\
\hline $38^{*}$ & $15^{\circ} 58,21^{\circ}$ & $122^{\circ} 57.68^{\circ}$ & 98.99 & 980666.73 & 0.72 & -19.68 & -30.27 \\
\hline 37 & $45^{\circ} 57.50^{\circ}$ & $122^{\circ} 58.20^{\circ}$ & 172.25 & 980647.47 & 0.44 & -15.28 & -34.35 \\
\hline $36 \dot{r}$ & $45^{\circ} 57.45^{\circ}$ & $122^{\circ} 58.11^{\prime}$ & 286.16 & 980614.20 & 0.83 & -14.09 & -34.39 \\
\hline 36 & $45^{\circ} 56.77$ & $122^{\circ} 58.33^{\prime}$ & 219.21 & 980631.27 & 0.45 & -15.89 & -40.28 \\
\hline 35 & $15^{\circ} 56.86^{\circ}$ & $122^{\circ} 58.63^{\prime}$ & 243.08 & 980627.49 & 0.49 & -12.43 & -39.45 \\
\hline 34 & $45^{\circ} 56.84^{\circ}$ & $122^{\circ} 58.89^{\circ}$ & 253.41 & 980625.32 & 0.57 & -11.39 & -39.53 \\
\hline 33 & $45^{\circ} 57.08^{\circ}$ & $122^{\circ} 59.18^{\circ}$ & 280.72 & 980621.31 & 0.58 & -7.34 & -38.55 \\
\hline 32 & $15^{\circ} 57.26^{\circ}$ & $122^{\circ} 59.48^{\circ}$ & 291.67 & 980619.48 & 0.66 & -6.06 & -38.44 \\
\hline 31 & $45^{\circ} 57.20^{\circ}$ & $122^{\circ} 59.74^{\circ}$ & 303.91 & 980616.85 & 0.82 & -4.83 & $-3 \hat{c} .43$ \\
\hline 30 & $45^{\circ} 57.17^{\circ}$ & $123^{\circ} 00.00^{\circ}$ & 308.09 & $9806 \div 5.95$ & 0.62 & -4.39 & $-38.6 E$ \\
\hline 29 & $45^{\circ} 57.22^{\circ}$ & $123^{\circ} 00.28^{\circ}$ & 292.66 & 980619.88 & 0.45 & -5.29 & -38.00 \\
\hline 28 & $45^{\circ} 57.35^{\circ}$ & $123^{\circ} 00.56^{\circ}$ & 274.16 & 980624.41 & 0.39 & $=6.67$ & -37.34 \\
\hline 27 & $15^{\circ} 57.47^{\prime}$ & $123^{\circ} 00.85^{\circ}$ & 262.20 & 980627.74 & 0.56 & -7.21 & -36.35 \\
\hline 26 & $15^{\circ} 57.68^{\prime}$ & $123^{\circ} 01.15^{\circ}$ & 264.42 & 980629.45 & 0.14 & -5.13 & -34.65 \\
\hline 25 & $45^{\circ} 57.73^{\circ}$ & $123^{\circ} 01.39^{\circ}$ & 246.42 & 980632.84 & 0.45 & -7.37 & -34.83 \\
\hline 24 & $45^{\circ} 57.78^{\prime}$ & $123^{\circ} 01.68^{\circ}$ & 246.10 & 980634.00 & 0.56 & -6.29 & -33.65 \\
\hline 23 & $15^{\circ} 57^{\prime} .92^{\circ}$ & $123^{\circ} 01.97^{\circ}$ & 280.37 & 980630.10 & 0.45 & +0.06 & $-3: .21$ \\
\hline $22 \mathrm{~A}$ & $45^{\circ} 57.80^{\prime}$ & $123^{\circ} 02.19^{\circ}$ & 235.89 & 980627.98 & 0.78 & -5.58 & -31.52 \\
\hline 22 & $15^{\circ} 57.43^{\circ}$ & $123^{\circ} 02.12^{\circ}$ & 237.87 & 980635.30 & 0.78 & -7.09 & -33.27 \\
\hline 21 & $45^{\circ} 56.85^{\prime}$ & $123^{\circ} 02.30^{\circ}$ & 258.62 & 980630.17 & 0.83 & -4.95 & -33.40 \\
\hline 20 & $45^{\circ} 56.78^{\prime}$ & $123^{\circ} 02.53^{\circ}$ & 273.12 & 980628.25 & 1.02 & -2.29 & $-32.2 \varepsilon$ \\
\hline 19 & $15^{\circ} 56.67^{\circ}$ & $123^{\circ} 02.78^{\circ}$ & 282.42 & 980623.76 & 0.95 & -3.75 & -34.77 \\
\hline 18 & $15^{\circ} 56.58^{\circ}$ & $123^{\circ} 03.05^{\circ}$ & 299.42 & 980619.99 & 2.24 & -2.14 & -34.79 \\
\hline 17 & $45^{\circ} 56.54^{\prime}$ & $123^{\circ} 03.30^{\circ}$ & 317.03 & 980617.07 & 0.85 & +0.43 & -34.61 \\
\hline 16 & $45^{\circ} 56.49^{\prime}$ & $123^{\circ} 03.55^{\circ}$ & 340.84 & 980612.19 & 0.69 & +2.98 & -34.93 \\
\hline 15 & $15^{\circ} 55.82^{\prime}$ & $123^{\circ} 03.68^{\prime}$ & 364.12 & 980605.54 & 1.11 & $+4,52$ & -35.59 \\
\hline 14 & $45^{\circ} 55.74^{\circ}$ & $123^{\circ} 03.95^{\circ}$ & 345.92 & 980608.11 & 1.78 & +1.59 & -35.80 \\
\hline 13 & $45^{\circ} 55.80^{\circ}$ & $123^{\circ} 04.22^{\circ}$ & 330.05 & 980612.65 & 1.61 & +1.15 & -34.61 \\
\hline 12 & $45^{\circ} 56.13^{\circ}$ & $123^{\circ} 04.55^{\circ}$ & 307.86 & 980618.46 & 2.08 & -0.39 & -32.28 \\
\hline 11 & $15^{\circ} 56.36^{\prime}$ & $123^{\circ} 04.82^{\circ}$ & 295.87 & 980621.93 & 2.45 & -0.96 & $-32 . \approx 2$ \\
\hline 10 & $15^{\circ} 56.52^{\prime}$ & $123^{\circ} 05.15^{\circ}$ & 290.02 & 980623.44 & 3.55 & -1.50 & $-30 .: 9$ \\
\hline 9 & $15^{\circ} 56.70^{\prime}$ & $123^{\circ} 05.12^{\circ}$ & 279.59 & 980627.25 & 3.54 & -1.27 & -29.30 \\
\hline 8 & $15^{\circ} 56.79^{\circ}$ & $123^{\circ} 05.68^{\prime}$ & 274.70 & 980629.56 & 3.34 & -0.51 & -28.43 \\
\hline 7 & $45^{\circ} 56.85^{\prime}$ & $223^{\circ} 05.95^{\circ}$ & 268.19 & 980631.84 & 2.85 & -0.33 & -27.56 \\
\hline 6 & $45^{\circ} 56.95^{\circ}$ & $123^{\circ} 06.60^{\circ}$ & 247.15 & 980638.52 & 1.87 & -0.29 & -26.43 \\
\hline 5 & $15^{\circ} 56.92$ & $123^{\circ} 07.20^{\circ}$ & 231.64 & 980644.48 & 1.57 & +0.93 & -23.74 \\
\hline 4 & $45^{\circ} 57.02^{\prime}$ & $123^{\circ} 07.94^{\circ}$ & 211.14 & 980651.78 & 1.81 & +1.76 & $-20.3 \equiv$ \\
\hline 3 & $45^{\circ} 56.98^{\circ}$ & $123^{\circ} 08.59^{\circ}$ & 192.47 & 980656.88 & 1.25 & +1.16 & $-19.4=$ \\
\hline 2 & $45^{\circ} 56.84^{\prime}$ & $123^{\circ} 09.23^{\circ}$ & 182.29 & $9 \mathrm{~B} 0661.76$ & 0.62 & +3.11 & -16.93 \\
\hline 1 & $15^{\circ} 56.77^{\prime}$ & $123^{\circ} 09.81^{\prime}$ & 171.12 & 980666.82 & 0.75 & +4.82 & -23.81 \\
\hline
\end{tabular}




\section{GRAVITY DATA CORRECTIONS}

Latitude - $1.307 \sin 2 \phi \mathrm{mgal} / \mathrm{mile}$

$$
\phi=\text { latitude }
$$

Free-Air - $0.3085 \mathrm{mgal} / \mathrm{m}$

Bouguer - $0.112 \mathrm{mgal} / \mathrm{m}$

Free Air anomaly $=O G-G \emptyset+F A C$

Bouguer anomaly $=\mathrm{OG}-\mathrm{G} \emptyset+\mathrm{FAC}-\mathrm{BC}+\mathrm{TC}$

OG - observed gravity

GØ - theoretical gravity

FAC - Free Air correction

$B C$ - Bouguer correction

TC - terrain correction

PSU base station:

Location: Lobby of Geology Department Office Cramer Hall, Room 17

Gravity: 980641.35 milligals, established using the 1930 International Formula. 


\section{DEEP WELL DATA USED IN GRAVITY MODELLING}

$\mathrm{T} 5 \mathrm{~N}, \mathrm{R} 5 \mathrm{~W}$, Sec. 14, $\mathrm{NW}^{\frac{1}{4}}$ *

Total depth 558 meters (1832 feet)

American Quasar Petroleum Co.

Crown Zellerbach \#14-21

All sediments.

$\mathrm{T} 4 \mathrm{~N}, \mathrm{R} 3 \mathrm{~W}, \mathrm{Sec} .8, \mathrm{NW}_{\frac{1}{4}}^{\frac{1}{4}}$ *

Total depth 1768 meters (5805 feet)

Reichhold Energy Corp.

"NNG-CZ" \#2

All sediments except volcanics from 870 to 930 meters.

T5N, R4W, Sec. 36, NW/

Total depth 1848 meters (6063 feet)

Reichhold Energy Corp.

Crown Zellerbach \#4

All sediments except volcanics from 745 to 760 meters.

Well locations noted on Figure 2 .

* Projected onto cross sections, Figures 14 and 17. 


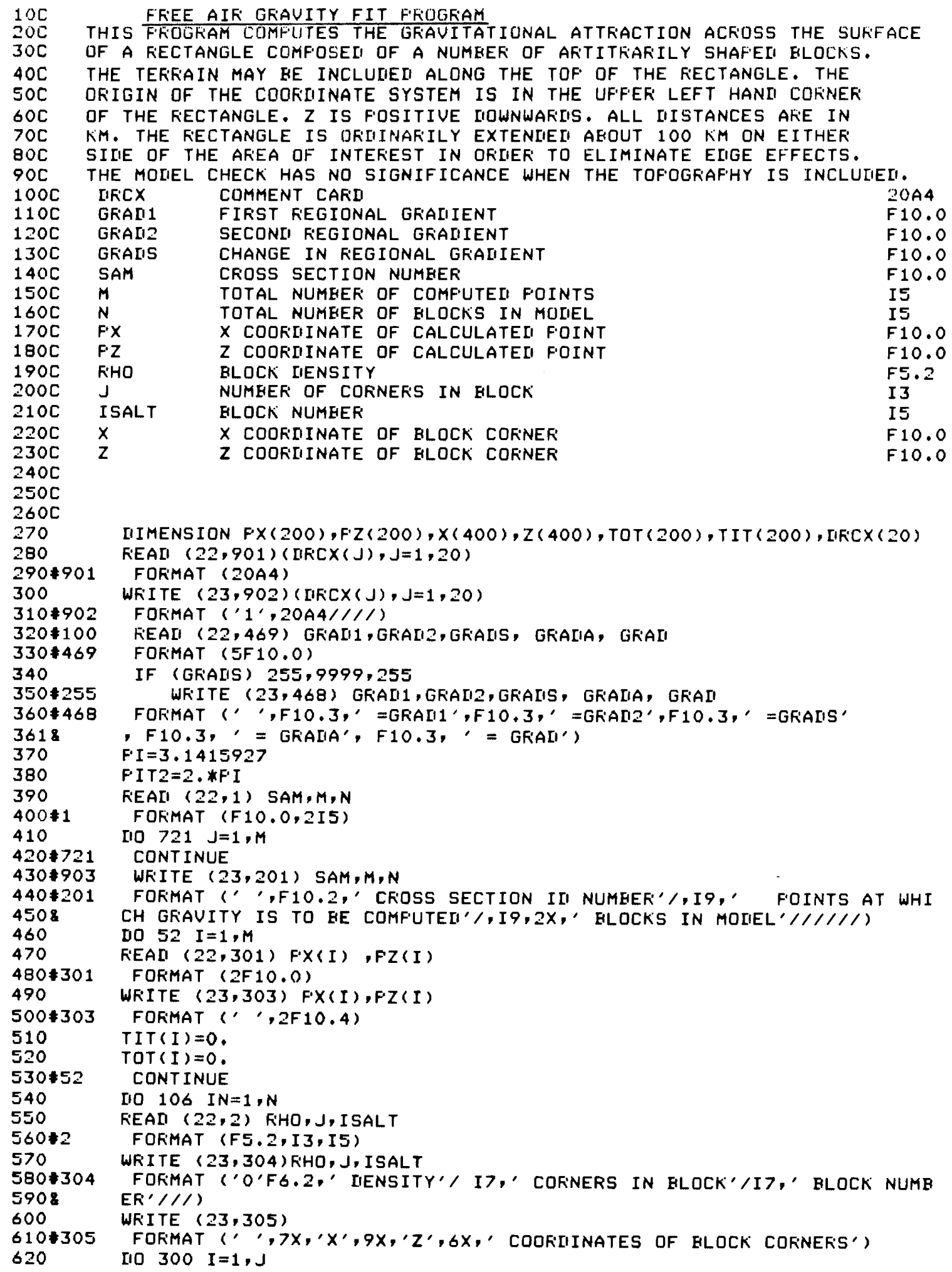




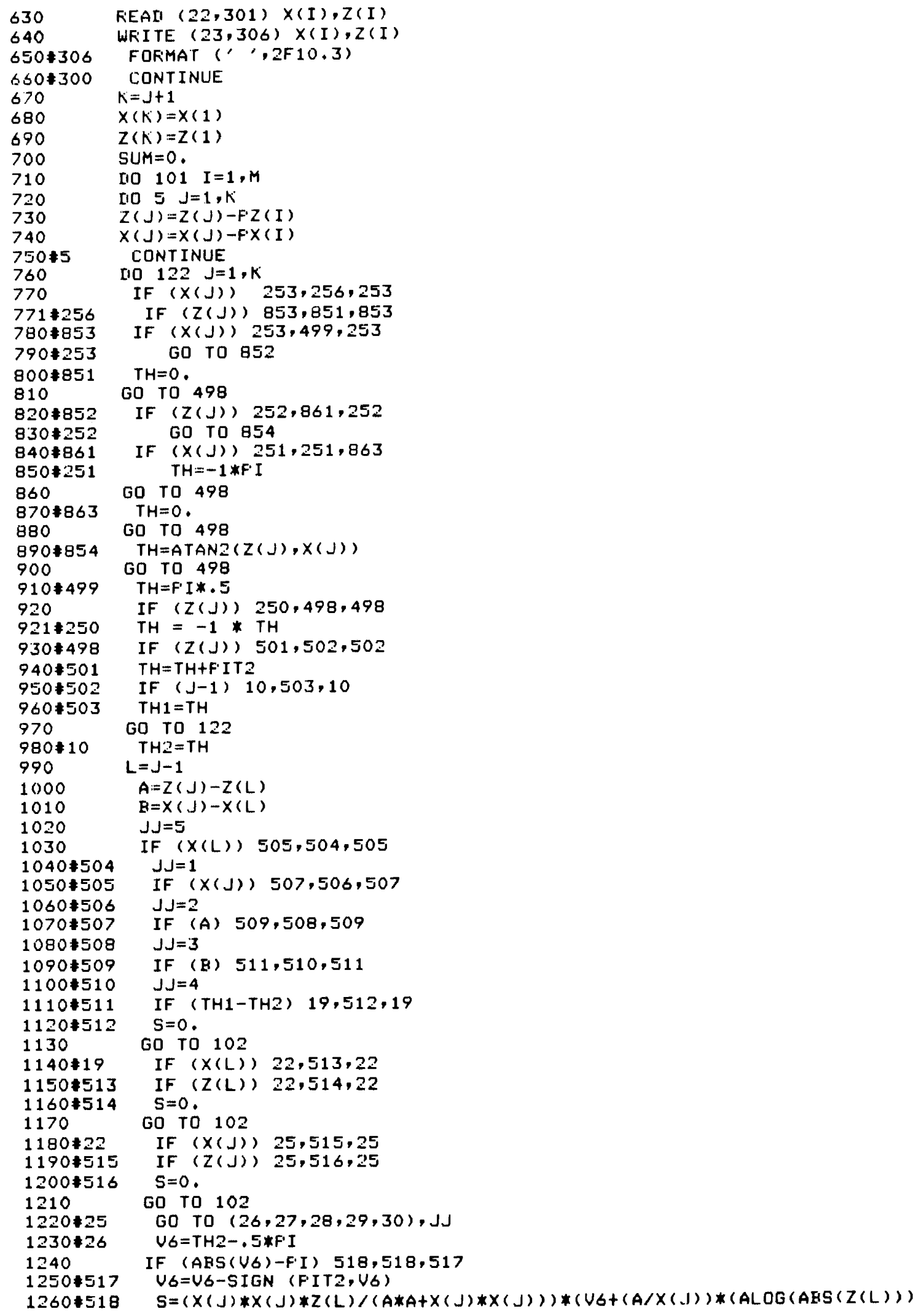




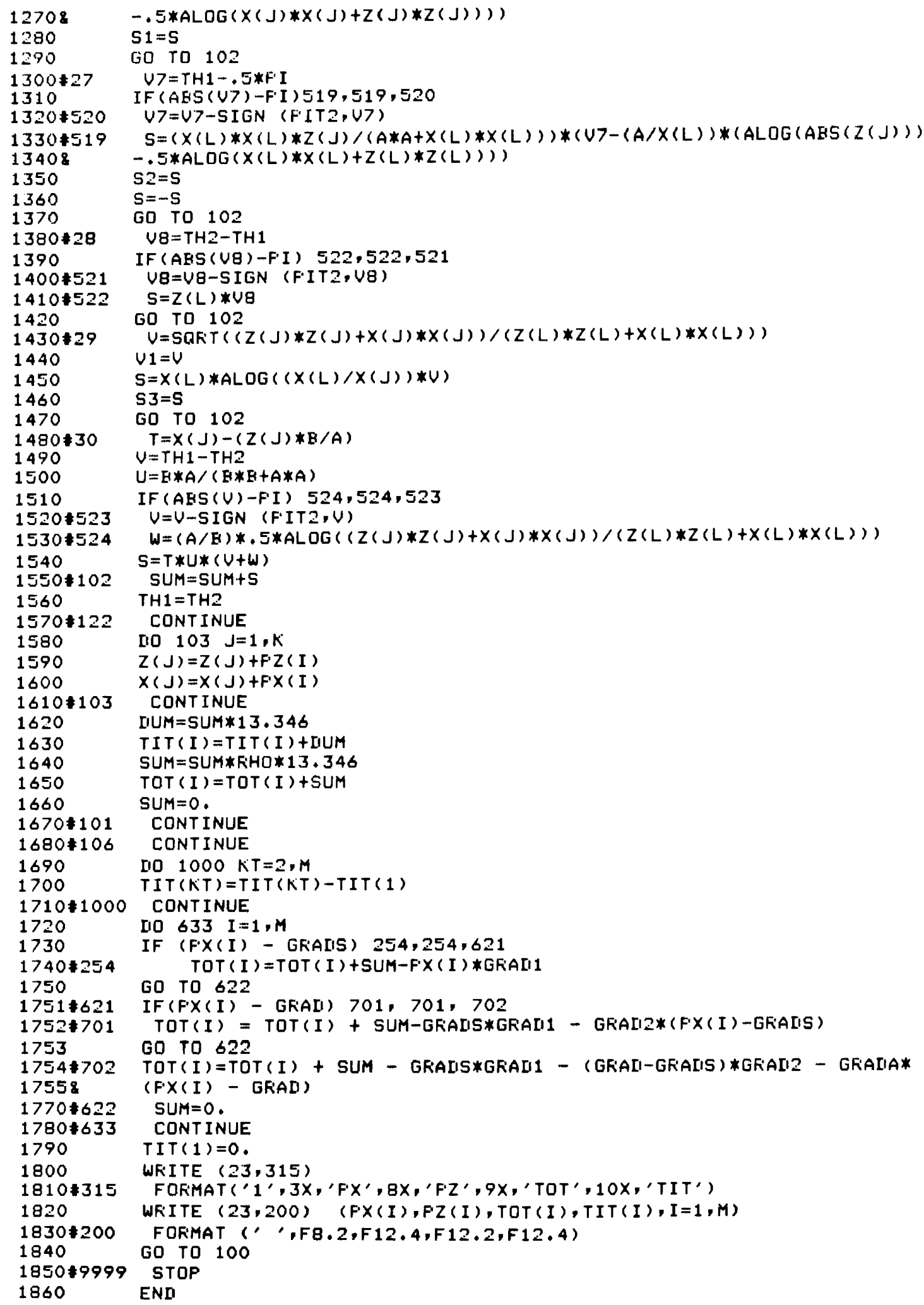


BUNKER HILL REFRACTION DATA

(East to West)

\begin{tabular}{|c|c|c|c|c|c|c|c|c|c|c|c|c|c|c|}
\hline \multirow[b]{2}{*}{ Line } & \multirow[b]{2}{*}{ Shotpoint } & \multirow[b]{2}{*}{1} & \multirow[b]{2}{*}{2} & \multirow[b]{2}{*}{3} & \multicolumn{2}{|c|}{ 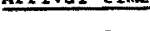 } & \multirow[b]{2}{*}{6} & \multirow[b]{2}{*}{7} & \multirow[b]{2}{*}{8} & \multirow[b]{2}{*}{9} & \multirow[b]{2}{*}{10} & \multirow[b]{2}{*}{11} & \multirow[b]{2}{*}{12} & \multirow{2}{*}{$\begin{array}{l}\text { Reeord } \\
\text { Qualizy }\end{array}$} \\
\hline & & & & & 1 & 5 & & & & & & & & \\
\hline \multirow[t]{4}{*}{$2200 E-1650 E$} & $1650 \mathrm{E}$ & 0 & .018 & .031 & .047 & .058 & .067 & .086 & .098 & .132 & .137 & .145 & .150 & B \\
\hline & $2200 E$ & .159 & .147 & .135 & .122 & .119 & .110 & .108 & .107 & .085 & .057 & .029 & 0 & B+ \\
\hline & $2750 E$ & .213 & .202 & .200 & .199 & .199 & .191 & .182 & .174 & .173 & .166 & .162 & .155 & D \\
\hline & $1100 E$ & .155 & .159 & .165 & .173 & .186 & .201 & .210 & .222 & .232 & .239 & .245 & .260 & $C$ \\
\hline \multirow[t]{4}{*}{$1650 \mathrm{E}-1100 \mathrm{E}$} & $1100 E$ & .118 & .115 & .110 & .101 & .089 & .079 & .067 & .057 & .045 & .036 & .025 & 0 & A \\
\hline & $1650 \mathrm{E}$ & 0 & .017 & .031 & .046 & .064 & .066 & .075 & .084 & .091 & .099 & .109 & .118 & B \\
\hline & $2200 E$ & .126 & .134 & .148 & .161 & .169 & .164 & .177 & .178 & .182 & .182 & .187 & .199 & $c-$ \\
\hline & $550 E$ & .185 & .175 & .170 & .168 & .162 & .156 & .148 & .142 & .137 & .135 & .132 & .126 & B \\
\hline \multirow[t]{4}{*}{$1100 \mathrm{E}-550 \mathrm{E}$} & $550 E$ & 0 & .027 & .040 & .050 & .060 & .074 & .081 & .093 & .099 & .105 & .114 & .124 & B \\
\hline & $1100 E$ & 0 & .029 & .041 & .053 & .064 & .076 & .080 & .087 & .097 & .107 & .116 & .125 & $\Lambda$ \\
\hline & $1650 E$ & .189 & .174 & .172 & .181 & .168 & .154 & .149 & .144 & .139 & .133 & .130 & .126 & B \\
\hline & $\mathrm{BH}-\mathrm{O}$ & .126 & .137 & .141 & .148 & .153 & .155 & .160 & .165 & .166 & .168 & .174 & .177 & $\mathbf{B}$ \\
\hline \multirow[t]{4}{*}{ 55OE-ВН-0 } & BH -0 & 0 & .033 & .042 & .053 & .067 & .076 & .084 & .093 & .106 & .115 & .124 & .134 & A \\
\hline & $550 E$ & .134 & .125 & .113 & .105 & .095 & .089 & .072 & .062 & .050 & .037 & .027 & 0 & $\mathbf{A}$ \\
\hline & $1100 \mathrm{E}$ & .185 & .177 & .176 & .174 & .167 & .159 & .157 & .147 & .140 & .135 & .132 & .126 & $\mathbf{B}$ \\
\hline & $550 \mathrm{H}$ & .126 & .129 & .135 & .140 & .149 & .152 & .159 & .164 & .169 & .174 & .185 & .191 & B \\
\hline \multirow[t]{4}{*}{$\mathrm{BH}-0-550 \mathrm{~W}$} & $\mathrm{BH}-\mathrm{O}$ & 0 & .015 & .027 & .039 & .051 & .062 & .067 & .077 & .086 & .094 & .100 & .105 & $c+$ \\
\hline & $550 \mathrm{~W}$ & .112 & .107 & .105 & .097 & .086 & .079 & .071 & .063 & .050 & .027 & .012 & 0 & B \\
\hline & $1100 \mathrm{H}$ & .160 & .159 & .159 & .161 & .149 & .148 & .144 & .138 & .138 & .134 & .127 & .126 & c \\
\hline & $550 E$ & .128 & .126 & .137 & .146 & .148 & .157 & .159 & .163 & .168 & .170 & .178 & .180 & B+ \\
\hline \multirow[t]{4}{*}{ j50w-1100w } & $550 \mathrm{H}$ & 0 & .012 & .026 & .047 & .062 & .072 & .080 & .093 & .103 & .108 & .120 & .125 & B \\
\hline & $1100 \mathrm{w}$ & .118 & .114 & .104 & .097 & .086 & .078 & .068 & .055 & .044 & .030 & .013 & 0 & A \\
\hline & $1650 \mathrm{H}$ & .181 & .169 & .167 & .166 & .159 & .155 & .150 & .145 & .139 & .135 & .129 & .126 & C \\
\hline & $\mathrm{BH}-0$ & .126 & .138 & .139 & .145 & .148 & .152 & .155 & .160 & .165 & .167 & .170 & .179 & $C+$ \\
\hline \multirow[t]{4}{*}{$1100 \mathrm{~W}-1650 \mathrm{H}$} & $1100 \mathrm{~W}$ & 0 & .013 & .032 & .044 & .057 & .068 & .072 & .080 & .088 & .097 & .106 & .113 & $C+$ \\
\hline & $1650 N$ & .121 & .119 & .105 & .095 & .085 & .080 & .068 & .066 & .050 & .037 & .020 & 0 & B \\
\hline & $2200 \mathrm{~W}$ & .188 & .188 & .186 & .176 & .170 & .168 & .160 & - & .150 & .148 & .131 & .126 & 0 \\
\hline & 55014 & .126 & .130 & .135 & .138 & .141 & .146 & .148 & .176 & .158 & .167 & .173 & .180 & $c$ \\
\hline \multirow[t]{4}{*}{$1650 \mathrm{~W}-2200 \mathrm{~W}$} & $1650 \mathrm{~W}$ & .103 & .100 & .102 & .094 & .081 & .075 & .065 & .058 & .047 & .031 & .019 & 0 & B \\
\hline & $2200 \mathrm{H}$ & 0 & .019 & .036 & .048 & .058 & .067 & .072 & .082 & .093 & .095 & .102 & .108 & $c+$ \\
\hline & $2750 W$ & .126 & .136 & .140 & .148 & .159 & .160 & .164 & .177 & .187 & .178 & .176 & .094 & D \\
\hline & $1100 \mathrm{~N}$ & .184 & .181 & .177 & .177 & .169 & .165 & .157 & .150 & .131 & .134 & .127 & .126 & C \\
\hline
\end{tabular}


SHAFFER ROAD REFRACTION DATA

(West to East)

\begin{tabular}{|c|c|c|c|c|c|c|c|c|c|c|c|c|c|c|}
\hline Line & shotpoint & 1 & 2 & 3 & 4 & 5 & 6 & 7 & 8 & 9 & 10 & 11 & 12 & $\begin{array}{l}\text { Record } \\
\text { Qual ity }\end{array}$ \\
\hline \multirow[t]{3}{*}{$0-550$} & 0 & 0 & .011 & .013 & .022 & .031 & .036 & .043 & .052 & .055 & .064 & .074 & .082 & $\mathrm{~B}+$ \\
\hline & 550 & .084 & .078 & .068 & .062 & .058 & .053 & .046 & .036 & .026 & .028 & .008 & 0 & A \\
\hline & 1100 & .090 & .101 & .111 & .119 & .121 & .131 & .135 & .140 & .140 & .150 & .153 & .162 & D \\
\hline \multirow[t]{3}{*}{$550-1100$} & 550 & .092 & .080 & .080 & .072 & .059 & .050 & .044 & .034 & .028 & .020 & .010 & 0 & $\mathrm{~B}+$ \\
\hline & 1100 & 0 & .004 & .010 & .014 & .022 & .027 & .028 & .041 & .059 & .066 & .077 & .098 & $c$ \\
\hline & 0 & - & .160 & .159 & .148 & .233 & .128 & .119 & .109 & .103 & .101 & .092 & .082 & D \\
\hline \multirow[t]{3}{*}{$1100-1650$} & 1100 & 0 & .013 & .018 & .020 & .021 & $.02 \mathrm{~B}$ & .030 & .033 & .041 & - & .045 & .052 & $c+$ \\
\hline & 1650 & .055 & .047 & .045 & .035 & .031 & .026 & .020 & .018 & .011 & .008 & .004 & 0 & D \\
\hline & 2200 & .060 & .080 & .090 & .098 & .118 & .147 & .158 & .172 & .184 & .202 & .218 & .248 & $\mathbf{F}$ \\
\hline \multirow[t]{4}{*}{$1650-2200$} & 1650 & .057 & .053 & .045 & .040 & .032 & .028 & .021 & .019 & .012 & .011 & .004 & 0 & B \\
\hline & 2200 & 0 & .004 & .013 & .015 & .019 & .024 & .027 & .028 & .028 & .038 & .054 & .062 & $\mathbf{B}$ \\
\hline & 2750 & .050 & .057 & .061 & .068 & .074 & .075 & .078 & .084 & .088 & .099 & .106 & .121 & $C+$ \\
\hline & 1100 & .180 & .142 & .119 & .104 & .097 & .082 & .080 & .080 & .077 & .071 & .071 & .065 & $E$ \\
\hline \multirow[t]{4}{*}{$2200-2750$} & 2200 & 0 & .013 & .017 & .022 & .023 & .028 & .032 & .032 & .038 & .047 & .048 & .059 & B+ \\
\hline & 2750 & .066 & .063 & .056 & .047 & .042 & .035 & .028 & .026 & .024 & .017 & .005 & 0 & B \\
\hline & 3300 & .182 & - & .121 & - & .129 & .091 & .088 & .082 & .097 & .092 & .088 & .070 & $\mathbf{F}$ \\
\hline & 1650 & .060 & .075 & .071 & .068 & .075 & .076 & - & .095 & - & - & - & - & $\mathbf{F}$ \\
\hline \multirow[t]{4}{*}{$2750-3300$} & 2750 & 0 & .021 & .025 & .032 & .036 & .042 & .044 & .051 & .054 & .059 & .066 & .072 & B+ \\
\hline & 3300 & .070 & .065 & .059 & .055 & .048 & .045 & .037 & .033 & .023 & .015 & .010 & 0 & $\mathbf{B}$ \\
\hline & 3850 & .165 & - & .158 & .148 & .161 & .157 & .147 & .131 & .124 & .116 & .104 & .095 & $D-$ \\
\hline & 2200 & .065 & .069 & .077 & .080 & .084 & .090 & .097 & .100 & .107 & .112 & .113 & .115 & $c-$ \\
\hline \multirow[t]{4}{*}{$3300-3850$} & 3300 & 0 & .009 & .013 & .025 & .029 & .038 & .045 & .049 & .054 & .058 & .068 & .084 & B- \\
\hline & 3850 & .095 & .091 & .080 & .065 & .053 & .050 & .044 & .043 & .034 & .025 & .015 & 0 & $c-$ \\
\hline & 4400 & .202 & .209 & .203 & .201 & .194 & .181 & .128 & .160 & .146 & .097 & .084 & .075 & D- \\
\hline & 2750 & .070 & .079 & .080 & .084 & .105 & .112 & .119 & .129 & .129 & .231 & .140 & .150 & D- \\
\hline \multirow[t]{3}{*}{$3850-4400$} & 3850 & 0 & .011 & .027 & .021 & .024 & .036 & .040 & .042 & .046 & .057 & .066 & .096 & $c$ \\
\hline & 4400 & .079 & .063 & .049 & .043 & .021 & .016 & .016 & .013 & .013 & .007 & 0 & .004 & $c$ \\
\hline & 3300 & .095 & .123 & .125 & .151 & .166 & .173 & .180 & .188 & .188 & .194 & .218 & - & D \\
\hline
\end{tabular}




\section{LITTLE CLATSKANIE REFRACTION DATA}

(West to East)

\begin{tabular}{|c|c|c|c|c|c|c|c|c|c|c|c|c|c|c|}
\hline \multirow[b]{2}{*}{ Line } & \multirow[b]{2}{*}{ Shotpoint } & \multirow[b]{2}{*}{1} & \multirow[b]{2}{*}{2} & \multirow{2}{*}{3} & \multirow{2}{*}{$\begin{array}{c}\text { Arrival } \\
4\end{array}$} & \multirow{2}{*}{$\begin{array}{c}t \text { ime } \\
5 \\
\end{array}$} & \multicolumn{2}{|c|}{ at geophone } & \multicolumn{2}{|c|}{ (seconds) } & \multirow[b]{2}{*}{10} & \multirow{2}{*}{11} & \multirow[b]{2}{*}{12} & \multirow{2}{*}{$\begin{array}{l}\text { Record } \\
\text { Quality }\end{array}$} \\
\hline & & & & & & & 6 & 7 & B & 9 & & & & \\
\hline \multirow[t]{3}{*}{$0-550$} & 0 & 0 & .005 & .009 & .015 & .016 & .021 & .024 & .034 & .038 & .045 & .057 &, 067 & B \\
\hline & 550 & .065 & .059 & .057 & .055 & .046 & .038 & .036 & .029 & .027 & .019 & .012 & o & B+ \\
\hline & 1100 & .217 & .204 & .243 & .232 & .222 & .222 & .222 & .172 & .155 & .134 & .134 & .115 & F- \\
\hline \multirow[t]{4}{*}{$550-1100$} & 550 & 0 & .014 & .023 & .033 & .046 & .065 & .066 & .076 & .082 & .088 & .098 & .115 & B- \\
\hline & 1100 & .112 & .108 & .102 & .091 & .087 & .089 & .066 & .054 & .037 & .025 & .013 & 0 & c \\
\hline & 1650 & .151 & .150 & .140 & .131 & .123 & - & .120 & .102 & .102 & .101 & .093 & .092 & $D-$ \\
\hline & 0 & .065 & .069 & .074 & .084 & .094 & .103 & .103 & .103 & .103 & .172 & .182 & - & F- \\
\hline \multirow[t]{4}{*}{$1100-1650$} & 1100 & .086 & .081 & .076 & .068 & .059 & - & .042 & .036 & .030 & .026 & .013 & 0 & B+ \\
\hline & 1650 & 0 & .015 & .027 & .042 & .052 & .058 & .062 & .065 & .076 & .081 & .084 & .092 & B \\
\hline & 2200 & .095 & .108 & .105 & .108 & .115 & .121 & .128 & .131 & .137 & .153 & .153 & .153 & $c-$ \\
\hline & 550 & .145 & .141 & .139 & .137 & .132 & .128 & .127 & .119 & .119 & .120 & .117 & .115 & D- \\
\hline \multirow[t]{4}{*}{$1650-2200$} & 1650 & 0 & .018 & .028 & .043 & .056 & .062 & .072 & .082 & .087 & .087 & .095 & .097 & B+ \\
\hline & 2200 & .090 & .090 & .083 & .076 & .076 & .072 & .062 & $.04 B$ & .038 & .027 & .011 & 0 & A- \\
\hline & 2750 & .184 & .179 & .173 & .168 & .166 & .166 & .147 & .136 & .128 & .126 & .119 & .116 & c \\
\hline & 1100 & .092 & .102 & .106 & .107 & .114 & .118 & .124 & .126 & .126 & .132 & .132 & .136 & ct \\
\hline \multirow[t]{4}{*}{$2200-2750$} & 2200 & o & - & .034 & .047 & .060 & .073 & .073 & .080 & .081 & .095 & .100 & .114 & B \\
\hline & 2750 & .104 & - & .094 & .090 & .076 & .072 & .059 & .057 & .039 & .033 & .016 & 0 & 8- \\
\hline & 3300 & .197 & .194 & .188 & .172 & .172 & .155 & .143 & .141 & .132 & .124 & .124 & .120 & $c-$ \\
\hline & 1650 & .095 & - & .101 & .107 & .113 & .123 & .130 & - & - & - & - & - & $\mathbf{F}$ \\
\hline \multirow[t]{4}{*}{$2750-3300$} & 2750 & 0 & .018 & .031 & .039 & .045 & .055 & .061 & .072 & .077 & .088 & .104 & .121 & B \\
\hline & 3300 & .117 & .111 & .090 & $.08 B$ & .072 & .061 & .051 & .046 & .033 & .020 & .009 & 0 & c \\
\hline & 3850 & .126 & .119 & .113 & .097 & .077 & .069 & .060 & .036 & .019 & .009 & .007 & a & D- \\
\hline & 2200 & .116 & .116 & .119 & .151 & .155 & .163 & .163 & .172 & .137 & .182 & .193 & .192 & $F$ \\
\hline
\end{tabular}




\section{REFRACTION DATA REDUCTION FORMULAS}

A. Critical angle, dip, depth and thickness of layers
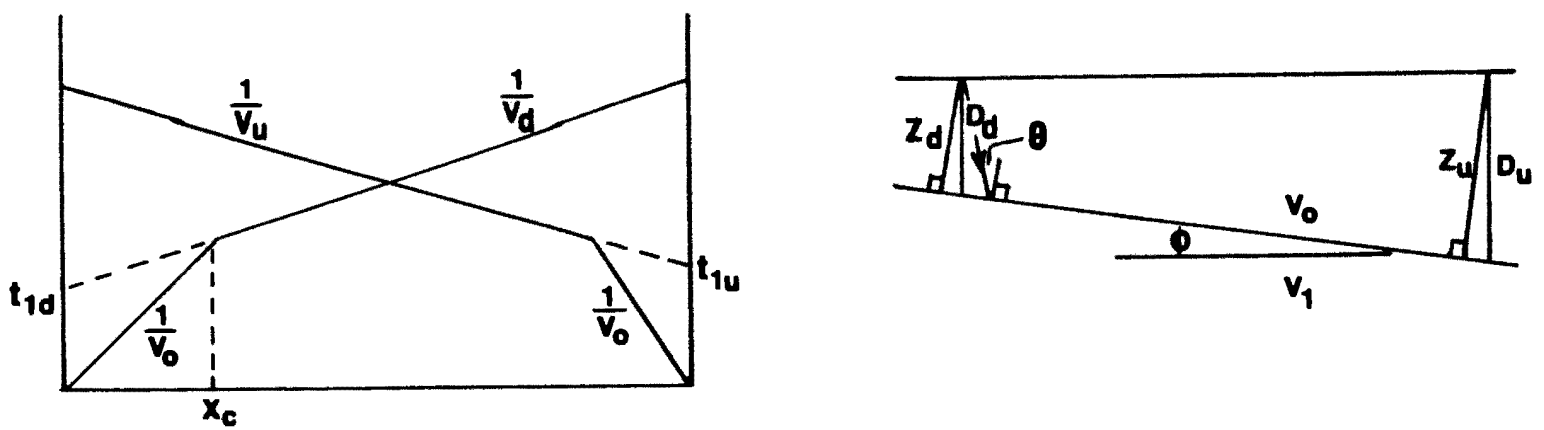

$$
\begin{array}{lcl}
\theta \text { (critical angio) }=\frac{1}{2}\left[\sin ^{-1} \frac{V_{0}}{V_{d}}+\sin ^{-1} \frac{v_{0}}{V_{u}}\right] & \sin \theta=\frac{v_{0}}{V_{1}} \\
\phi(d i p) & =\frac{1}{2}\left[\sin ^{-1} \frac{V_{0}}{V_{d}}-\sin ^{-1} \frac{V_{0}}{V_{u}}\right] & V_{u}>v_{d} \\
Z_{d}=\frac{t_{1 d} V_{0}}{2 \cos \theta} & Z_{u}=\frac{t_{1 u} V_{0}}{2 \cos \theta} \\
D_{d}=\frac{Z_{d}}{\cos \phi} & D_{u}=\frac{Z_{u}}{\cos \phi}
\end{array}
$$

Multiple dipping layer formulas in Ewing. Woollard and Vine, 1938. and Mote, 1054.
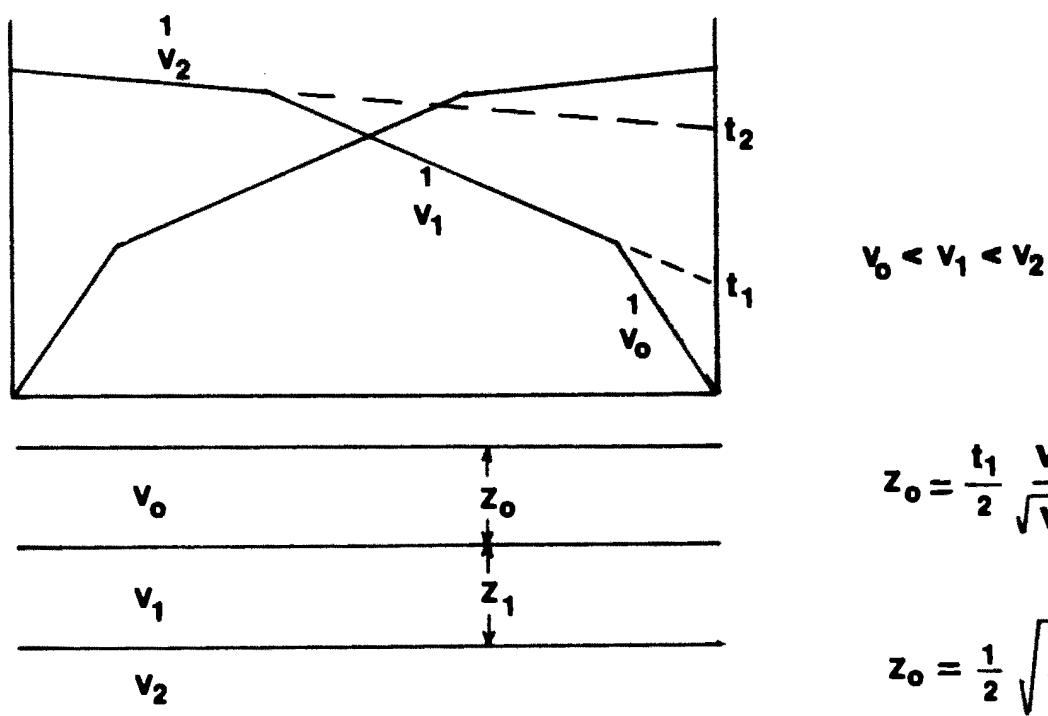

$$
\begin{aligned}
& z_{0}=\frac{t_{1}}{2} \frac{v_{1} v_{0}}{\sqrt{v_{1}^{2}-v_{0}^{2}}} \\
& z_{0}=\frac{1}{2} \sqrt{\frac{v_{1}-v_{0}}{v_{1}+v_{0}}} x_{c}
\end{aligned}
$$

$$
z_{1}=\frac{1}{2}\left(t_{2}-2 z_{0} \frac{\sqrt{v_{2}^{2}-v_{0}^{2}}}{v_{2} v_{0}}\right)\left(\frac{v_{2} v_{1}}{\sqrt{v_{2}^{2}-v_{1}^{2}}}\right)
$$

As a quick approximation $\frac{x_{c}}{2} \leq z$. 
105

B. Fault throw:

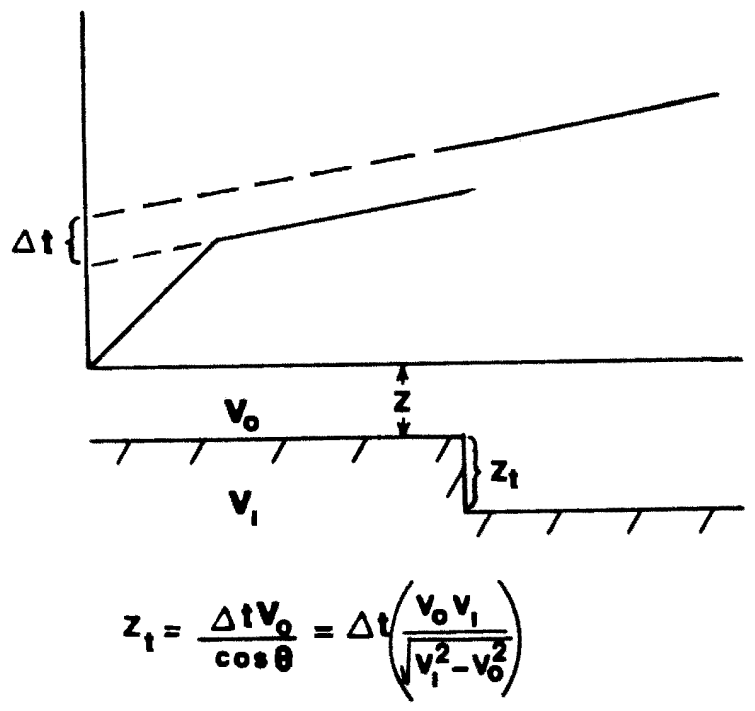

C. Elevation correction:

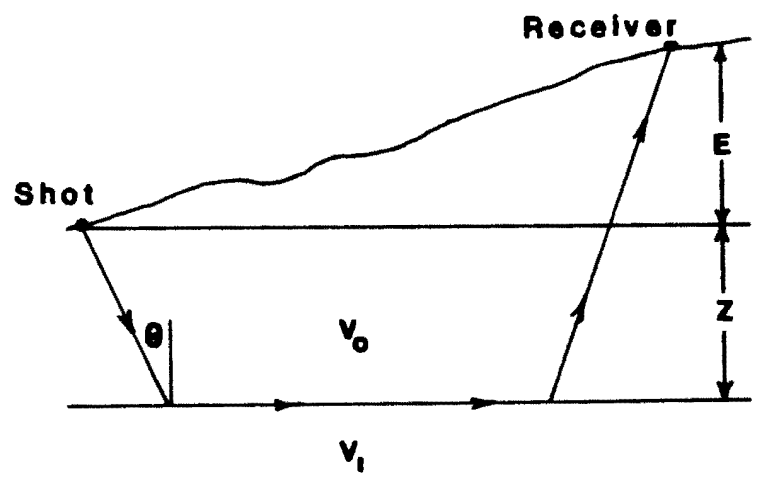

Depth to $v_{0} / v_{1}$ interface $=z+\frac{E}{2}$. 
APPENDIX C

BUNKER HILL MAGNETIC DATA

(East to West)

\begin{tabular}{|c|c|c|c|c|c|}
\hline Station & Gammas & Station & Gammas & Station & Gammas \\
\hline $\mathrm{BH}-0$ & 55523 & 420 & 55370 & 1235 & 56715 \\
\hline E2750 & 55107 & 315 & 55366 & 1345 & 56725 \\
\hline 2650 & 55331 & 265 & 55400 & 1450 & 56380 \\
\hline 2550 & 55504 & 240 & 55786 & 1560 & 56609 \\
\hline 2450 & 54930 & 210 & 55935 & 1665 & 56329 \\
\hline 2350 & 55626 & 160 & 55934 & 1765 & 56062 \\
\hline 2250 & 55894 & 135 & 55786 & 1365 & 55913 \\
\hline 2145 & 55697 & 110 & 55569 & 1965 & 55606 \\
\hline 2040 & 55826 & $\mathrm{Bii}-0$ & 55515 & 2065 & 55630 \\
\hline 1935 & 55884 & 105 & 55559 & 2165 & 55381 \\
\hline 1830 & 55436 & 210 & 55419 & 2275 & 55263 \\
\hline 1725 & 55353 & 310 & 55481 & 2380 & 55381 \\
\hline 1630 & 55651 & 365 & 55563 & 2485 & 55390 \\
\hline 1530 & 55575 & 395 & 55724 & 2590 & 55383 \\
\hline 1435 & 55663 & 415 & 55415 & 2700 & 55524 \\
\hline 1335 & 55664 & 520 & 55812 & 2800 & 55455 \\
\hline 1240 & 55638 & 615 & 56004 & $\mathrm{BH}-\mathrm{O}$ & 55524 \\
\hline 1140 & 55603 & 720 & 55992 & & \\
\hline 1040 & 55664 & 820 & 55818 & & \\
\hline 935 & 55539 & 870 & 56440 & & \\
\hline 830 & 55248 & 920 & 56613 & & \\
\hline 725 & 55186 & 975 & 56763 & & \\
\hline 620 & 55190 & 1025 & 56775 & & \\
\hline 525 & 55211 & 1125 & 56447 & & \\
\hline *Distance & in feet & east & st of & o fFigure & $10)$. \\
\hline
\end{tabular}


SHAFFER ROAD MAGINETIC DATA

(East to West)

\begin{tabular}{|c|c|c|c|c|}
\hline Station * & Gammas & Station & Gammas & \\
\hline 52200 & 55850 & 1685 & 55175 & \\
\hline 3950 & 55012 & 1580 & 55033 & \\
\hline 3850 & 54884 & 1470 & 54889 & \\
\hline 3745 & 54777 & 1365 & 55453 & \\
\hline 3640 & 54809 & 1255 & 55654 & \\
\hline 3540 & 54586 & 1145 & 55341 & \\
\hline 3435 & 55078 & 1055 & 55333 & \\
\hline 3330 & 54626 & 950 & 55056 & \\
\hline 3230 & 54715 & 845 & 55086 & \\
\hline 3125 & 54591 & 740 & 54963 & \\
\hline 3025 & 54910 & 635 & 54961 & \\
\hline 3925 & 55377 & 540 & 55046 & \\
\hline 2820 & 55527 & 435 & 55073 & . \\
\hline 2720 & 55701 & 330 & 55081 & \\
\hline 2620 & 55352 & 230 & 55186 & \\
\hline 2520 & 55866 & 125 & 55130 & \\
\hline 2420 & 55982 & 20 & 55203 & \\
\hline 2320 & 55712 & -80 & 55221 & \\
\hline 2220 & 55986 & 52200 & 55829 & \\
\hline$s 2200$ & 55834 & & & \\
\hline 2120 & 55909 & & & \\
\hline 2010 & 55556 & & & \\
\hline 1905 & 54884 & & & \\
\hline 1795 & 55040 & & & \\
\hline •Distance & in feet & from west & end of & line (Figure 12 ) \\
\hline
\end{tabular}


LITTLE CLATSKANIE MAGNETIC DATA

(West to East)

\begin{tabular}{|c|c|c|c|}
\hline Station* & Gammas & Station & Gammas \\
\hline $\mathrm{LCl} 650$ & 56353 & 2175 & 55467 \\
\hline LC-O & 56333 & 2270 & 55481 \\
\hline 100 & 56539 & 2370 & 55186 \\
\hline 200 & 56601 & 2465 & 54968 \\
\hline 300 & 54981 & 2560 & 54800 \\
\hline 400 & 54268 & 2655 & 54953 \\
\hline 500 & 54372 & 2750 & 54942 \\
\hline 600 & 54505 & 2840 & 54961 \\
\hline 700 & 55019 & 2935 & 55066 \\
\hline 800 & 54578 & 3025 & 55018 \\
\hline 900 & 55101 & 3120 & 55027 \\
\hline 1000 & 55324 & 3210 & 54987 \\
\hline 1100 & 55369 & 3300 & 54964 \\
\hline 1205 & 55026 & 3395 & 54923 \\
\hline 1310 & 55870 & 3490 & 54971 \\
\hline 1410 & 56282 & 3590 & 54975 \\
\hline 1515 & 56405 & 3685 & 54992 \\
\hline 1620 & 56466 & 3780 & 54992 \\
\hline LCl 650 & 56356 & 3880 & 55043 \\
\hline 1715 & 55948 & 3975 & 55165 \\
\hline 1810 & 55932 & LCl 650 & 56341 \\
\hline 1900 & 55901 & & \\
\hline 1995 & 55440 & & \\
\hline 2085 & 55413 & & \\
\hline
\end{tabular}


WATER WELL DATA USED IN REFRACTION MODELLING

$\mathrm{T} 4 \mathrm{~N}, \mathrm{R} 2 \mathrm{~W}$, Sec. 6, SW $\frac{1}{4} \mathrm{NE} \frac{1}{4}$ (Bunker Hill line)

Total depth 150 feet

$$
\begin{array}{r}
0 \text { - } 82 \text { feet clay } \\
82 \text { - } 150 \text { feet basalt }
\end{array}
$$

$\mathrm{T} 4 \mathrm{~N}, \mathrm{R} 2 \mathrm{~W}$, Sec. 6, SW $\frac{1}{4} \mathrm{NW}^{\frac{1}{4}}$ (Bunker Hill line) *

Total depth 200 feet

$$
\begin{array}{r}
0-125 \text { feet clay } \\
125-200 \text { feet broken rock }
\end{array}
$$

$\mathrm{T} 5 \mathrm{~N}, \mathrm{R} 3 \mathrm{~W}$, Sec. 3, $\mathrm{SE}_{\frac{1}{4}}^{\frac{1}{4}} \mathrm{NE}^{\frac{1}{4}}$ (Shaffer Road line) *

Total depth 483 feet

$$
\begin{aligned}
0-60 \text { feet clay } \\
60-158 \text { feet sandy clay } \\
158=455 \text { feet basalt } \\
455-483 \text { feet sandstone }
\end{aligned}
$$

Well locations noted on Figures 2,10 and 12 .

* Projected on cross sections, Figures 19, 20, 21, 22. 